\title{
EVOLUTION AND ADOPTION OF UML-BASED DEVELOPMENT TOOLS by
}

\author{
Rodolfo Napoles
}

\begin{abstract}
A thesis submitted to the Faculty of Graduate Studies and Research in partial fulfillment of the requirements for the degree of Master of Engineering in Telecommunications Technology Management Department of Systems and Computer Engineering
\end{abstract}

Carleton University

Ottawa, Canada, K1S 5B6

January 13,2005

(C) 2005 Rodolfo Napoles 


$\begin{array}{ll}\begin{array}{l}\text { Library and } \\ \text { Archives Canada }\end{array} & \begin{array}{l}\text { Bibliothèque et } \\ \text { Archives Canada }\end{array} \\ \begin{array}{l}\text { Published Heritage } \\ \text { Branch }\end{array} & \begin{array}{l}\text { Direction du } \\ \text { Patrimoine de l'édition }\end{array} \\ \begin{array}{l}\text { 395 Wellington Street } \\ \text { Ottawa ON K1A ON4 }\end{array} & \begin{array}{l}\text { 395, rue Wellington } \\ \text { Ottawa ON K1A ON4 } \\ \text { Canada }\end{array}\end{array}$

Your file Votre référence

ISBN: 0-494-00768-0

Our file Notre référence

ISBN: 0-494-00768-0

NOTICE:

The author has granted a nonexclusive license allowing Library and Archives Canada to reproduce, publish, archive, preserve, conserve, communicate to the public by telecommunication or on the Internet, loan, distribute and sell theses worldwide, for commercial or noncommercial purposes, in microform, paper, electronic and/or any other formats.

The author retains copyright ownership and moral rights in this thesis. Neither the thesis nor substantial extracts from it may be printed or otherwise reproduced without the author's permission.
AVIS:

L'auteur a accordé une licence non exclusive permettant à la Bibliothèque et Archives Canada de reproduire, publier, archiver, sauvegarder, conserver, transmettre au public par télécommunication ou par l'Internet, prêter, distribuer et vendre des thèses partout dans le monde, à des fins commerciales ou autres, sur support microforme, papier, électronique et/ou autres formats.

L'auteur conserve la propriété du droit d'auteur et des droits moraux qui protège cette thèse. $\mathrm{Ni}$ la thèse ni des extraits substantiels de celle-ci ne doivent être imprimés ou autrement reproduits sans son autorisation.
In compliance with the Canadian

Privacy Act some supporting forms may have been removed from this thesis.

While these forms may be included in the document page count, their removal does not represent any loss of content from the thesis.
Conformément à la loi canadienne sur la protection de la vie privée, quelques formulaires secondaires ont été enlevés de cette thèse.

Bien que ces formulaires aient inclus dans la pagination, il n'y aura aucun contenu manquant.

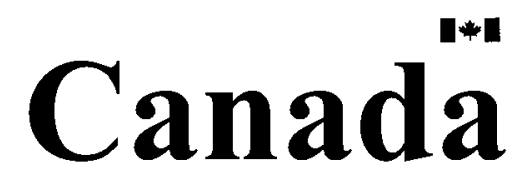




\section{Abstract}

This research tests nine hypotheses to examine the evolution and adoption of development tools that use the Unified Modeling Language (UML). Data for 70 suppliers and 53 buyers of these tools were used to: (i) measure the associations between stages of the life-cycle, supplier size, and product category, (ii) identify the temporal patterns of product, supplier and buyer diversity, and new suppliers and new buyers, and (iii) identify the reasons for which suppliers and buyers commit to development tools that use the Unified Modeling Language. The results are relevant to: (i) researchers interested in the adoption and diffusion of new technologies, (ii) product managers and sales managers of development tools, and (iii) market analysts. This research: (i) develops a method to identify reasons for buyer and seller commitment to UML-based development tools, and (ii) validates the densitydependence model using buyer data on UML-based development tools. 


\section{Acknowledgements}

I wish to express my gratitude to: God for my life and for allowing me to reach this goal; to my wife, Sandra, for providing her unconditional support and taking care of everything while I was working on this research; to my children Jesus Adrian, Luis Eduardo, and Ivan Alexandro for understanding why I could not play with them for several years; to my parents for the education and guidance they gave me; to my friends to whom many times I said I could not attend their parties; to Bran Selic for allowing me to browse through his files to look for information on UML-based development tools; to Wayne H. Zhang and John Buja for accepting to proof read this document with a very short notice; and to my thesis supervisor Professor Tony Bailetti for his guidance and patience throughout this research. 


\section{Table of contents}

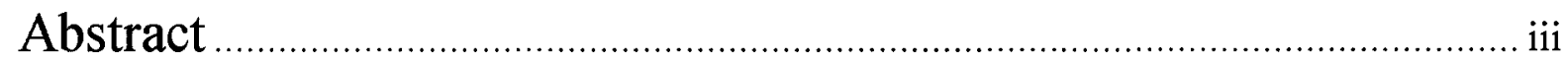

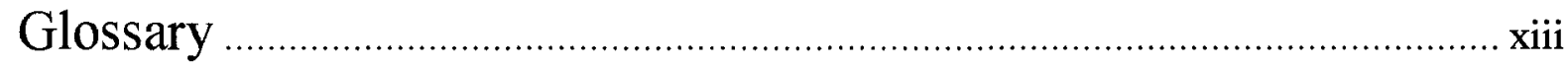

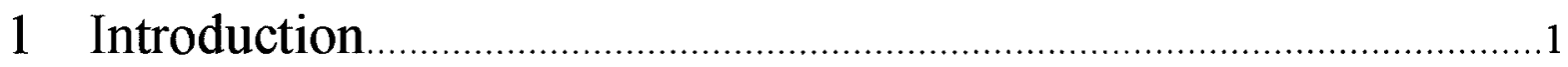

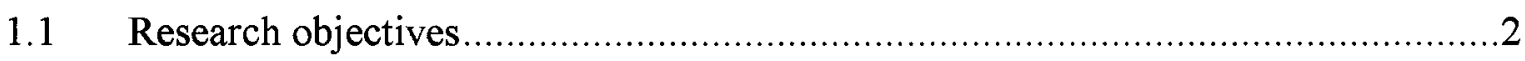

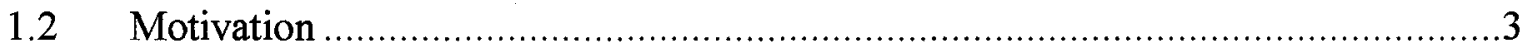

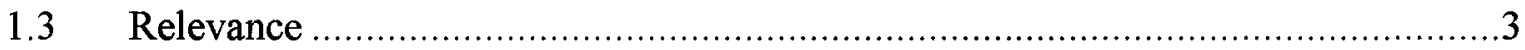

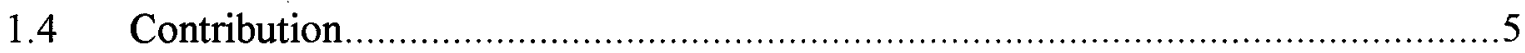

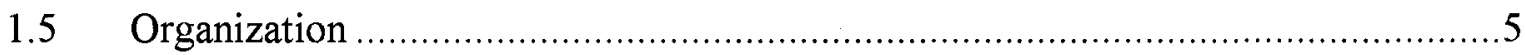

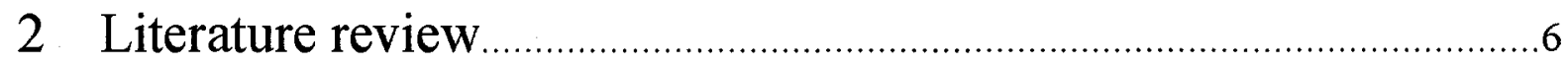

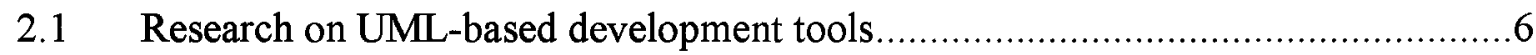

2.1.1 Role of the unified modeling language in UML-based development tools......6

2.1.2 Characteristics of models..................................................................

2.2 Research on theories of technology adoption............................................

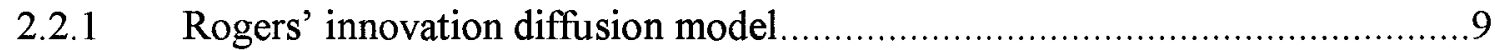

2.2.2 Moore's technology adoption life-cycle model ................................ 10

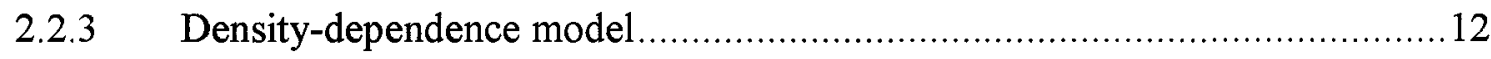

2.3 Segmentation of primary software markets........................................... 13

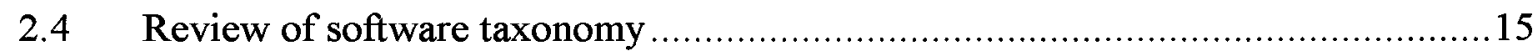

2.5 Lessons learned from reviewing the literature ...................................... 17

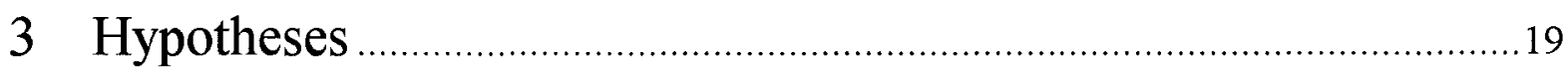

3.1 Comparing supplier and product attributes across adoption stages ....................19 
3.2 Temporal patterns of supplier and product diversity ...................................20

3.3 Temporal patterns of new suppliers and new buyers...................................21

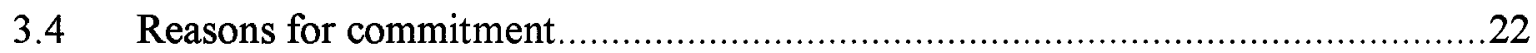

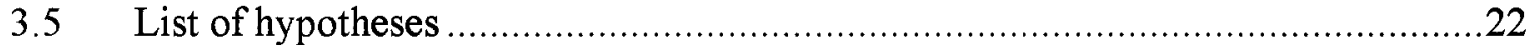

4 Research method …….............................................................................24

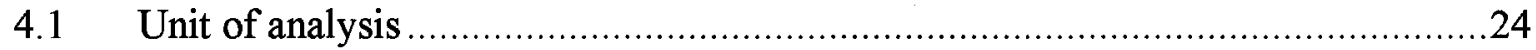

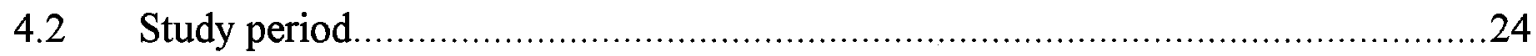

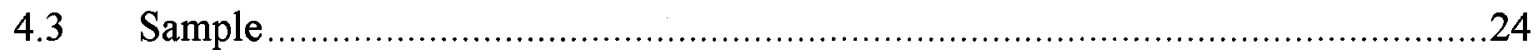

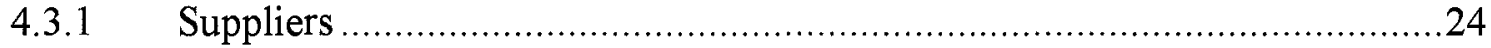

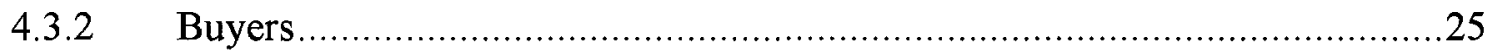

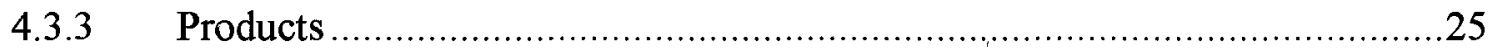

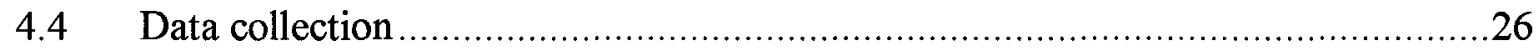

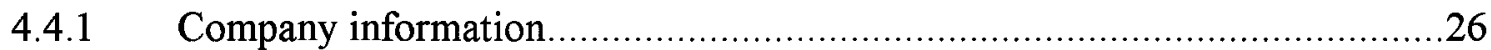

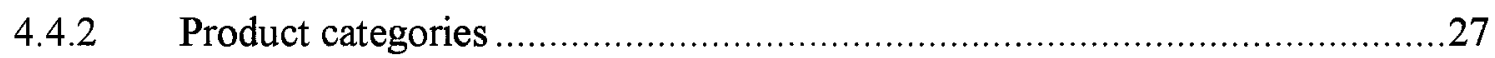

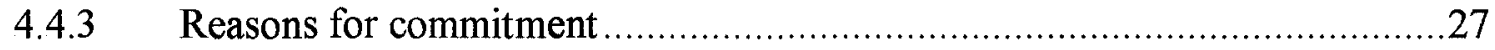

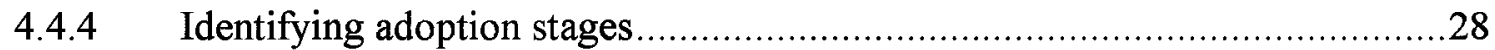

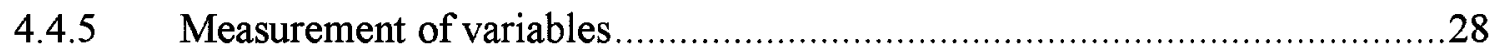

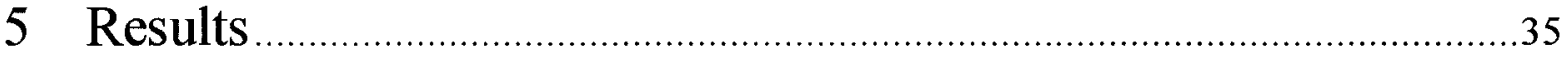

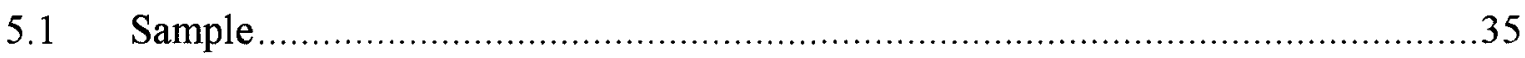

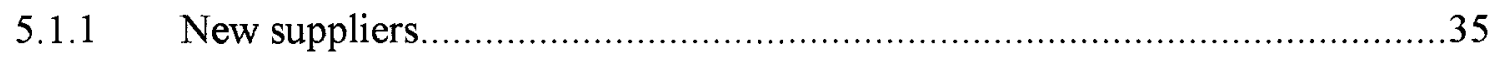

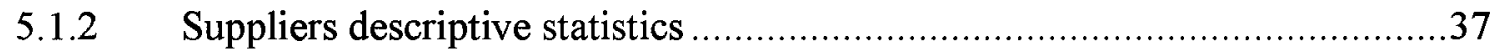

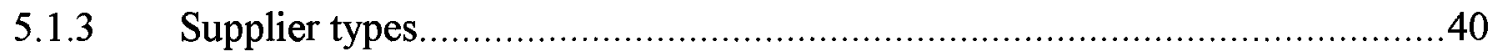

5.1.4 Suppliers' annual revenue, age, and size ........................................... 41

vi 


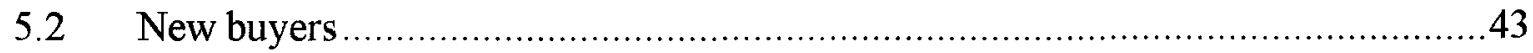

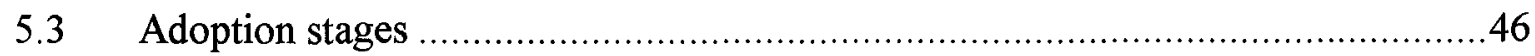

5.3.1 Changes in product types identified from buyers' data .................................46

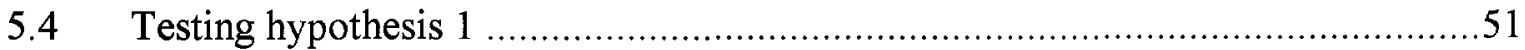

5.5 Products sample

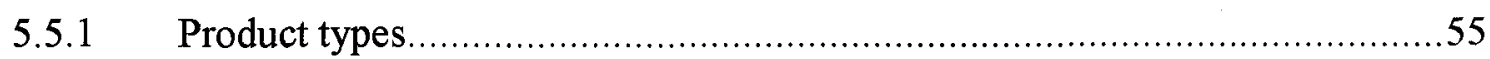

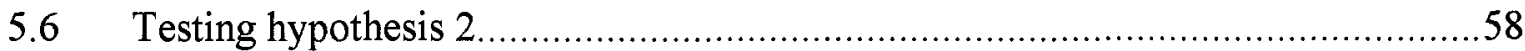

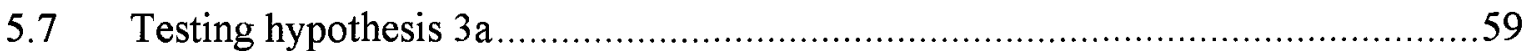

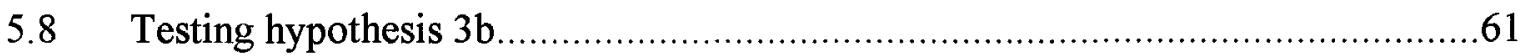

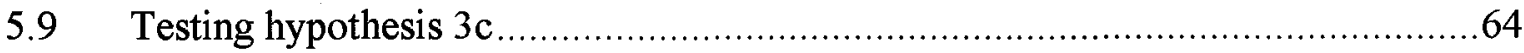

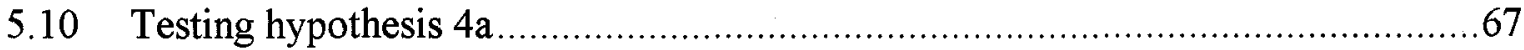

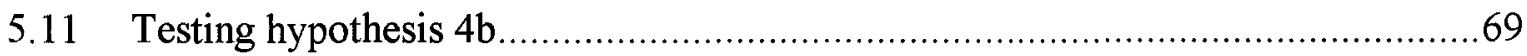

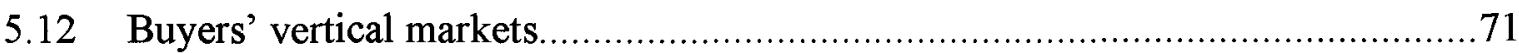

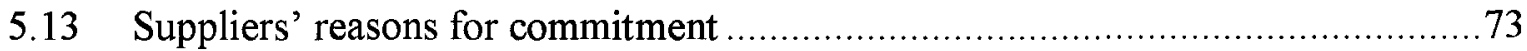

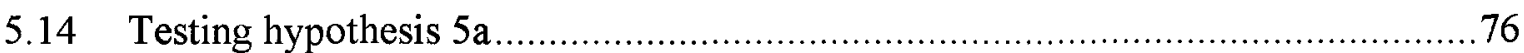

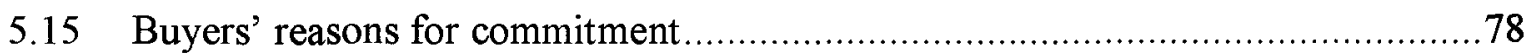

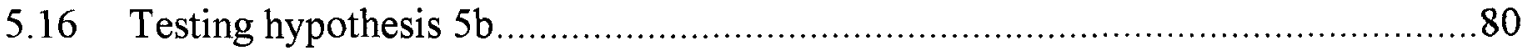

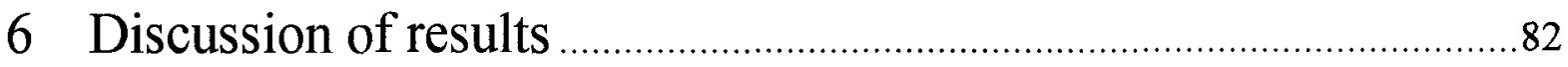

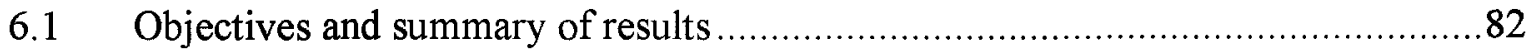

6.2 Association between adoption stage and supplier size and product category .........84

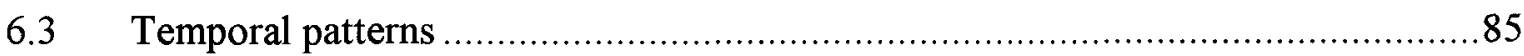

6.4 Commitment to UML-based development tools ..............................................85

6.5 Suppliers' reasons to commit to UML-based development tools...........................86

vii 
6.6 Buyers' reasons to commit to UML-based development tools .........................87

6.7 UML-based development tools technology adoption life-cycle .......................87

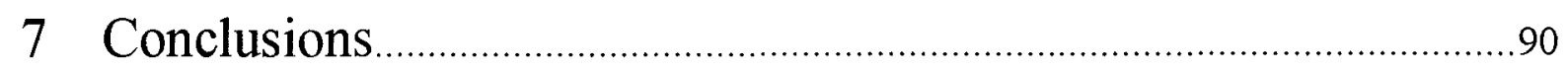

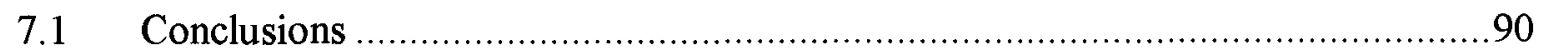

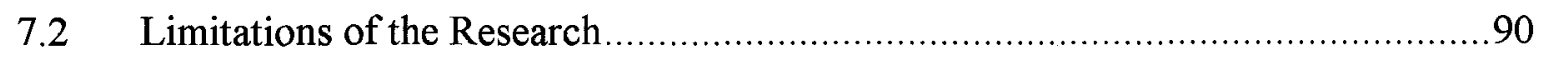

7.3 Suggestions for Future Research ......................................................91

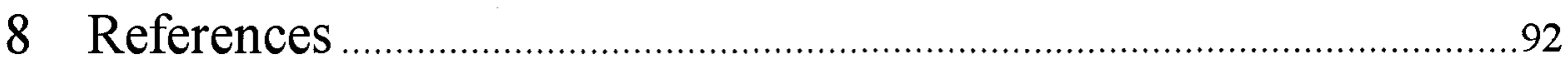




\section{List of tables}

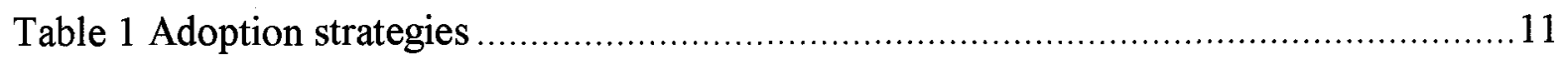

Table 2 IDC's primary markets and software markets definition.................................13

Table 3 Vertical markets by sector............................................................... 14

Table 4 IDC's taxonomy for application design and construction tools ......................... 16

Table 5 Number of suppliers identified by source of information................................36

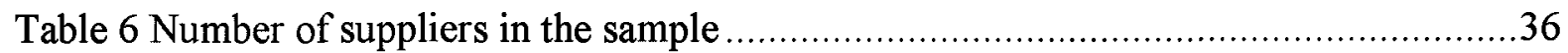

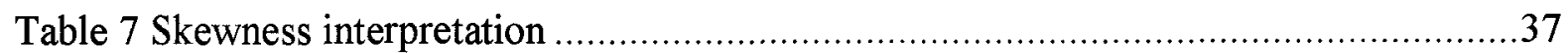

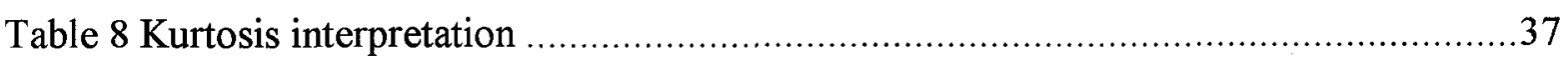

Table 9 Descriptive statistics for suppliers' entry rate density and diversity ......................38

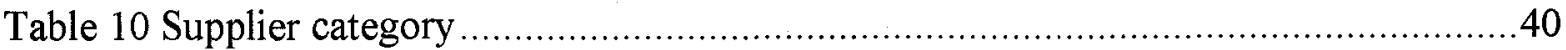

Table 11 Descriptive statistics for supplier's annual revenue, size, and age ...................42

Table 12 Descriptive statistics for buyers' entry rate, density and diversity .....................44

Table 13 Potential stage transitions identified from buyers' data .................................49

Table 14 Percent of buyers by product type and potential stage ...................................50

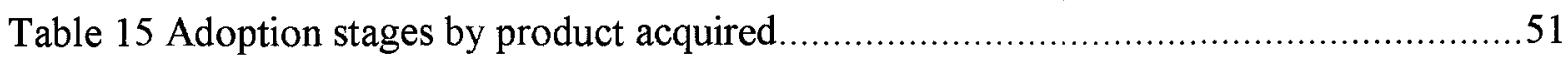

Table 16 Mann-Whitney U Test comparing suppliers' size between stages.......................52

Table 17 Descriptive statistics for variables that describe the characteristics of products .....53

Table 18 Number of products by product category .................................................56

Table 19 Descriptive statistics for product categories.......................................57

Table 20 Mann-Whitney $\mathrm{U}$ test comparing product types between stages ..........................58

Table 21 Descriptive statistics for product diversity by stage ...................................60

Table 22 Mann-Whitney $U$ test comparing product diversity between stages .....................61 
Table 23 Descriptive statistics for supplier diversity by stage

Table 24 Mann-Whitney $U$ test comparing supplier diversity between stages 63

Table 25 1-way between subjects ANOVA Supplier diversity by stage. 64

Table 26 Descriptive statistics for buyer diversity by stage. 66

Table 27 Mann-Whitney U test comparing buyer diversity between stages 67

Table 28 Descriptive statistics for buyers' entry rate by adoption stage. 68

Table 29 Descriptive statistics for buyers' entry rate by adoption stage. 68

Table 30 Descriptive statistics for suppliers' entry rate by adoption stage 70

Table 31 Mann-Whitney U test comparing suppliers' entry rate between stages 70

Table 32 Number of buyers by category based on vertical market. 72

Table 33 Descriptive statistics for buyers' vertical market 73

Table 34 Suppliers reasons to commit keywords. 74

Table 35 Frequency distribution for suppliers' reasons to commit. 74

Table 36 Suppliers' reasons for commitment categorical summary descriptive statistics ......75

Table 37 Mann-Whitney U test comparing suppliers' reasons to commit between stages.....78

Table 38 Buyers' reasons to commit keywords 79

Table 39 Frequency distribution for buyers' reasons to commit 79

Table 40 Buyers' reasons to commitment categorical summary descriptive .79

Table 41 Mann-Whitney U test comparing buyers' reasons to commit between stages 81

Table 42 Summary of results 83 


\section{List of figures}

Figure 1 Technology-based market development ................................................. 11

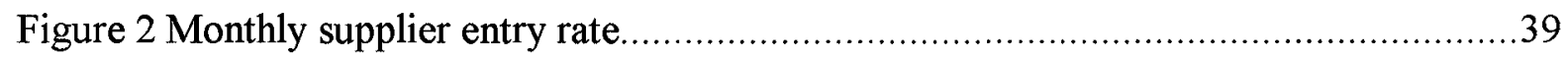

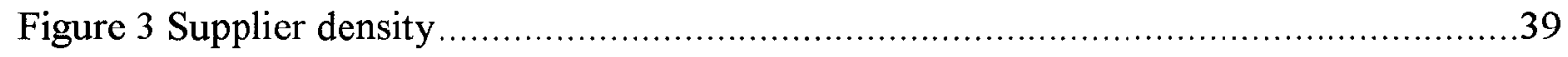

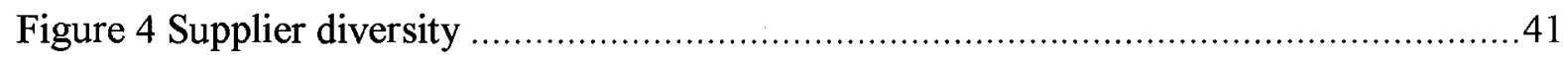

Figure 5 Histogram for suppliers' annual revenue, age, and number of employees.............42

Figure 6 New buyers entry rate......................................................................... 45

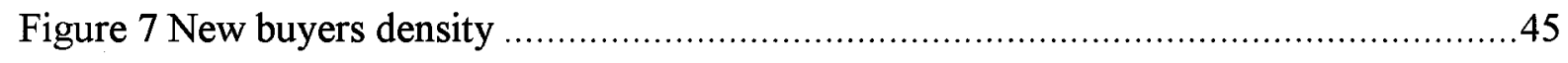

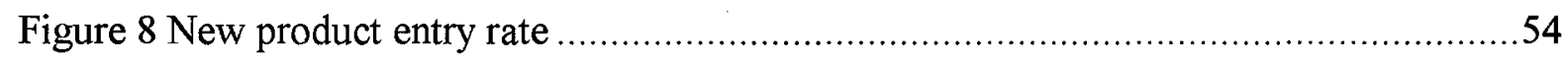

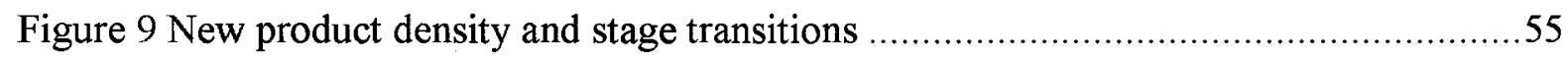

Figure 10 Product diversity and stage transition ....................................................57

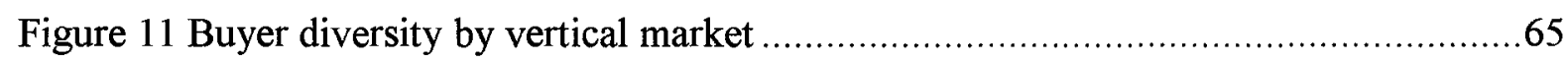

Figure 12 Suppliers' reasons for commitment........................................................ 75

Figure 13 Frequency distribution for buyer's reasons to commitment ........................8

Figure 14 UML-based development tools technology adoption life-cycle ....................88

Figure 15 Alternate UML-based development tools technology adoption life-cycle............89 


\section{List of appendices}

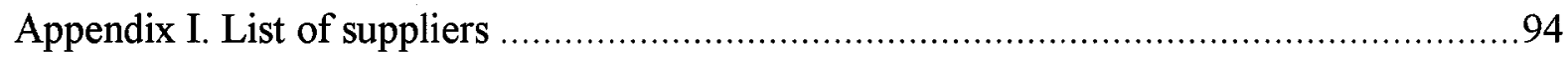

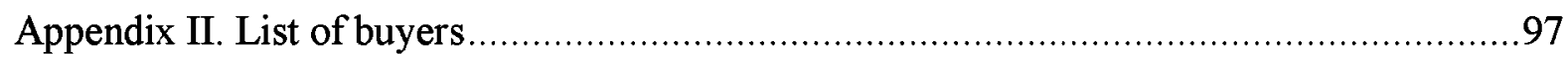

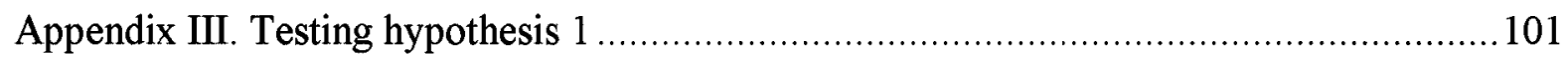

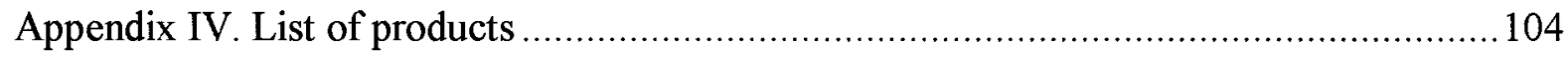

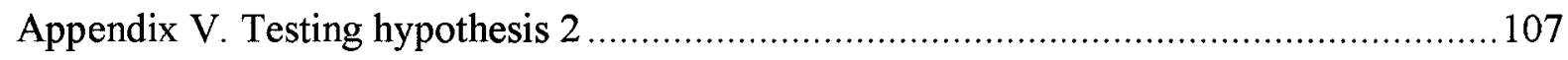

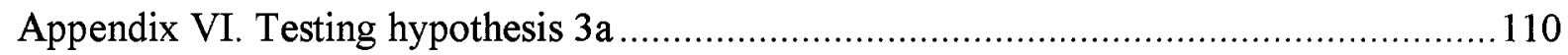

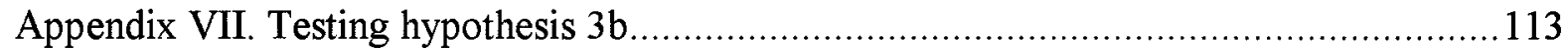

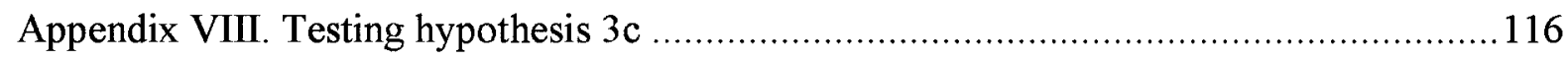

Appendix IX. Testing hypothesis 4a ……...............................................................119

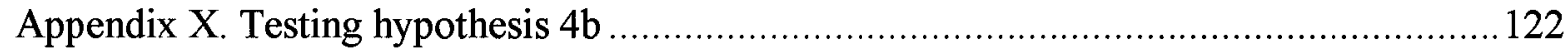

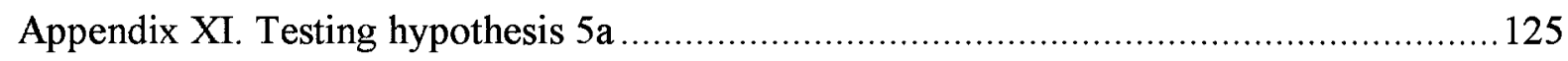

Appendix XII. Testing hypothesis 5b 


\section{Glossary}

Artifact. A physical piece of information that is used or produced by a software development process. Examples of Artifacts include models, source files, scripts, and binary executable files. An artifact may constitute the implementation of a deployable component (Rational Unified Process Glossary, Version 2003.06.0065).

Eclipse. A platform designed to build integrated development environments (IDEs) that can be used to create applications from $\mathrm{C}++$ programs to websites and Enterprise JavaBeans (EJB) applications.

IDE. Integrated development environment.

MDA. See model-driven architecture.

MDD. See UML-based development.

Model. A semantically closed abstraction of a system (Rational Unified Process Glossary, Version 2003.06.0065).

Model-driven architecture (MDA). A way of writing specifications and developing applications, based on a platform-independent model (PIM).

xiii 
UML-based development (MDD). A way of developing software applications by using methodologies that assist in the identification and documentation of application requirements, data definitions, and programming specifications.

Object management architecture (OMA). An architecture that provides guidance on how standardization of component interfaces penetrate up - although not into - applications in order to create a plug-and-play component software environment based on object technology.

Object-oriented programming. (OOP) A programming approach based on the concepts of data abstraction and inheritance. Unlike procedural programming techniques, object-oriented programming concentrates on those data objects that constitute the problem and how they are manipulated, not on how something is accomplished (Rational Unified Process Glossary, Version 2003.06.0065).

OMA. See object management architecture.

Open source. A certification standard issued by the Open Source Initiative (OSI) that indicates that the source code of a computer program is made available free of charge to the general public.

Platform. The underlying hardware or software for a system. 
Unified modeling language (UML). A language for visualizing, specifying, constructing, and documenting the artifacts of a software-intensive system. 


\section{Introduction}

For the purpose of this research, a UML-based development tool is a software product that uses the unified modeling language (UML) notation to visualize, construct, and document the artifacts of software systems with the objective to automate and accelerate software construction. The scope of this research is limited to software tools that use software models only. Mathematical models and any other sort of models are excluded from this research.

UML-based development tools support methodologies that assist in the identification and documentation of application requirements, data definitions, and programming specifications. They also provide automated support for at least one object-oriented methodology and for some or all of the software development life-cycle phases. UML-based development tools reduce software development cycle-time and increase product quality (Kirzner, 2003).

Some software development tools providers are moving application development to higher levels of abstraction, specifically through visual modeling and in most cases using UML as the modeling language of choice.

UML-based development tools allow designers to build models using concepts that are closer to the problem domain. This makes models easier to specify, understand, and maintain. 
The model for a software application can be thought of as the equivalent to the blueprint of a skyscraper building. The concepts used to build the blueprint are close to the domain understood by those who are familiar with skyscrapers.

A key principle of UML-based development tools is that code can be automatically generated from models. This makes models platform-independent, reducing or eliminating the high cost of making changes to the underlying technology.

UML-based development tools became available in 1991 with the release of development tools that generate code from a system model (e.g., Objectime ToolSet). The number of tools increased with the advent of the unified modeling language.

According to Kirzner (2003), IBM's acquisition of Rational Software and Borland's acquisition of Togethersoft dramatically changed the UML-based development tools industry. Both IBM and Borland have plans to integrate UML-based development tools into full life-cycle application development suites.

\subsection{Research objectives}

This research examines the worldwide adoption of UML-based development tools from January 1991 to December 2003. The specific research objectives are to:

1) Examine whether the stages of the life cycle affect supplier size and product type. 
2) Identify the temporal patterns of product diversity, supplier diversity, and buyer diversity as well as new suppliers' and buyers' entry rates.

3) Identify the reasons for which suppliers and buyers commit to UML-based development tools.

\subsection{Motivation}

The increasing adoption of UML-based development tools during the last decade, particularly the last three years, was the main motivation for this study. Since their introduction in 1991, UML-based development tools have been seen as a means to automate software development tasks such as software coding and code-model synchronization. Traditional engineering disciplines use models to understand complex problems and to aid in their solution. In the past, models were rarely used in software engineering and when used they played a secondary role. Even after the unified modeling language was adopted by the Object Management Group (OMG) in 1995, the number of suppliers of UML-based development tools did not increase considerably.

\subsection{Relevance}

To the knowledge of the author, this is the first empirical study on the adoption of UMLbased development tools.

Temporal patterns of buyers across stages of the adoption life cycle are of interest to product and sales managers and temporal patterns of suppliers are of interest to buyers. The study of 
these temporal patterns is also of interest to academics (Debackere, Koenraad, Clarysse, 1998; Klepper, 1996).

The reasons for which suppliers commit to UML-based development tools are of special interest to buyers and suppliers. The reasons for which buyers commit to UML-based development tools are of special interest to product managers, sales managers, and market analysts.

This research builds on the theoretical perspective developed by Keppler (1996) and Debackere et al. (1998) and the thesis completed by Peng (2004). There are three main differences between this thesis and that developed by Peng (2004). First, Peng's research focused on the adoption of a technical infrastructure anchored around Linux, an open source operating system. This thesis focuses on the adoption of mostly proprietary applications.

The second difference is that Peng uses suppliers' data to identify adoption stage transitions. In this research, buyer data is used to identify the adoption stage transitions.

The third difference between Peng's work and this research is that the hypotheses are tested using data on both suppliers and buyers. 


\subsection{Contribution}

This research makes three important contributions. First, it measures the strength of the association between stages of the adoption life cycle and the attributes of buyers and suppliers of UML-based development tools. Second, to the knowledge of the author, this is the first empirical study that identifies the reasons for buyer and seller commitment to UMLbased development tools. Third, it uses buyer data to determine the stages of its adoption life cycle.

\subsection{Organization}

This research is organized into seven chapters. Chapter one is the introduction. Chapter two provides a review of the relevant literature. Chapter three defines the research hypotheses. Chapter four explains the research method. Chapter five provides the results. Chapter six discusses the results. Chapter seven draws conclusions, lists the limitations of the research, and identifies opportunities for future research. 


\section{Literature review}

This chapter is organized into five sections. Section 2.1 reviews the literature on UML-based development tools. Section 2.2 reviews the literature on theories of technology adoption. Section 2.3 summarizes the segmentation of primary software markets, software segments, and vertical market analysis provided by International Data Corporation (Kirzner, 2003). Section 2.4 summarizes the software taxonomy provided by International Data Corporation (Heiman, 2003). Finally, section 2.5 provides lessons learned from this literature review.

\subsection{Research on UML-based development tools}

\subsubsection{Role of the unified modeling language in UML-based development tools}

Modeling is the designing of software applications before coding. Projects of all sizes, from large to small, can take advantage of modeling, a task that must be considered an essential part in all software development projects. Modeling helps to visualize a design and validate the requirements before coding starts. Since it is not bonded to the underlying technology with which it will be implemented, anyone familiar with the unified modeling language notation can understand the model (Selic, 2003). UML-based development tools exploit these features of the unified modeling language to provide modeling and forward-engineering capabilities (e.g., the generation of code out of the model). 
The unified modeling language can also be used to analyze the existing source code by translating it into a set of unified modeling language diagrams. UML-based development tools exploit this feature to offer reverse engineering (e.g., the creation of models out of the source code).

Advanced features of UML-based development tools include round-trip engineering, so if the code or model is modified the tool will automatically update the model or code accordingly.

Full benefits of UML-based development tools can only be achieved when the application provides automatic generation of complete programs instead of just code skeletons, automatically verifying models, for example, by executing them, although this feature can have impact on performance (Selic, 2003).

Kristina Joukhadar makes a comparison of what the Java mantra is with what the Object Management Group's (OMG) mantra should be: "If Java's mantra is Write once, run anywhere, the mantra of the Object Management Group's new Model Driven Architecture specification should be Design once, build it on any platform." (Joukhadar, 2001)

\subsubsection{Characteristics of models}

In order for a model to be effective, it must possess the following five characteristics (Selic, 2003): 
Abstraction. The removal of common features of objects and procedures to help understand the essence more easily.

Understandability. The outcome of the abstraction must be represented in a way that requires reduced effort to understand it.

Accuracy. The model must represent a true-to-life representation of the modeled system's feature of interest (Selic, 2003).

Predictiveness. The ability to use the model to correctly predict the modeled systems' interesting but non-obvious properties, through experimentation or through some type of formal analysis (Selic, 2003).

Inexpensive. It most be significantly cheaper to construct and analyze than the modeled system. (Selic, 2003)

In summary, the unified modeling language is a cornerstone for any UML-based development tool. 


\subsection{Research on theories of technology adoption}

\subsubsection{Rogers' innovation diffusion model}

Rogers (1983) defined an innovation diffusion model in which organizations respond to an innovation offer. Two variables were used to develop an adoptee categorization: the mean and standard deviation. Five groups of adopters are identified by Rogers: 1) the innovators are those who adopt the new technology offer immediately after it becomes available on the market because the technology is interesting to the them; 2) early adopters are those who embrace the new technology offer to use it as an advantage against their competitors; 3) early majority are those that adopt the technology only after the early adopters demonstrate they had a benefit with it; 4), late majority are those that embrace the new technology only after the majority of the population on the system have adopted it; and 5) laggards, by the time laggards adopt the technology, there might already be available a newer technology (Rogers, 1983).

The innovation diffusion model follows a normal distribution that represents the adoption rate of a new technology over time and a S-curve that represents a cumulative number of adopters. 


\subsubsection{Moore's technology adoption life-cycle model}

The technology adoption life-cycle (TALC) has a bell-shaped distribution representing the total population of people exposed to the new technology offer; it also shows how the technology-based markets evolve (Moore, 2002). Four main stages are identified:

Early market, offering an immature product targeted to technology enthusiasts and visionaries who want to try the new technology because the underlying technology is interesting. The link to the market is through professional services and the suppliers' objective is to gain flagship accounts.

Crossing the chasm into the bowling alley, offering an application-like product targeted to niches of pragmatic customers. The link to the market is a solution to a problem that cannot be resolved with the current well-known applications available in the market. The suppliers' objective is to win a niche, then to try to expand to other niches.

Inside the tornado, offering commodity-like products targeted to technical buyers. The supplier's objective is to sell large amounts of the same offer.

Main street, offering extended commodity-like products targeted to end-users. The supplier's objective is to mass customize. 
Moore categorizes the population into five groups of buyers according to their adoption strategy. Table 1 shows the five groups and their adoption strategies. Figure 1 shows the technology-based market development from Moore's perspective.

Table 1 Adoption strategies

\begin{tabular}{|l|l|}
\hline Buyer groups & \multicolumn{1}{|c|}{ Adoption strategy } \\
\hline Enthusiast & $\begin{array}{l}\text { Adopt the new offer because it is interesting and wish to explore its } \\
\text { properties }\end{array}$ \\
\hline Visionary & $\begin{array}{l}\text { Adopt the new offer to create dramatic advantages over the } \\
\text { competitors who do not adopt it }\end{array}$ \\
\hline Pragmatist & Adopt the new offer when others have successfully implemented it \\
\hline Conservative & Put off adopting the new offer as long as possible to conserve cash \\
\hline Skeptic & Refuse to adopt the new offer \\
\hline
\end{tabular}

Figure 1 Technology-based market development

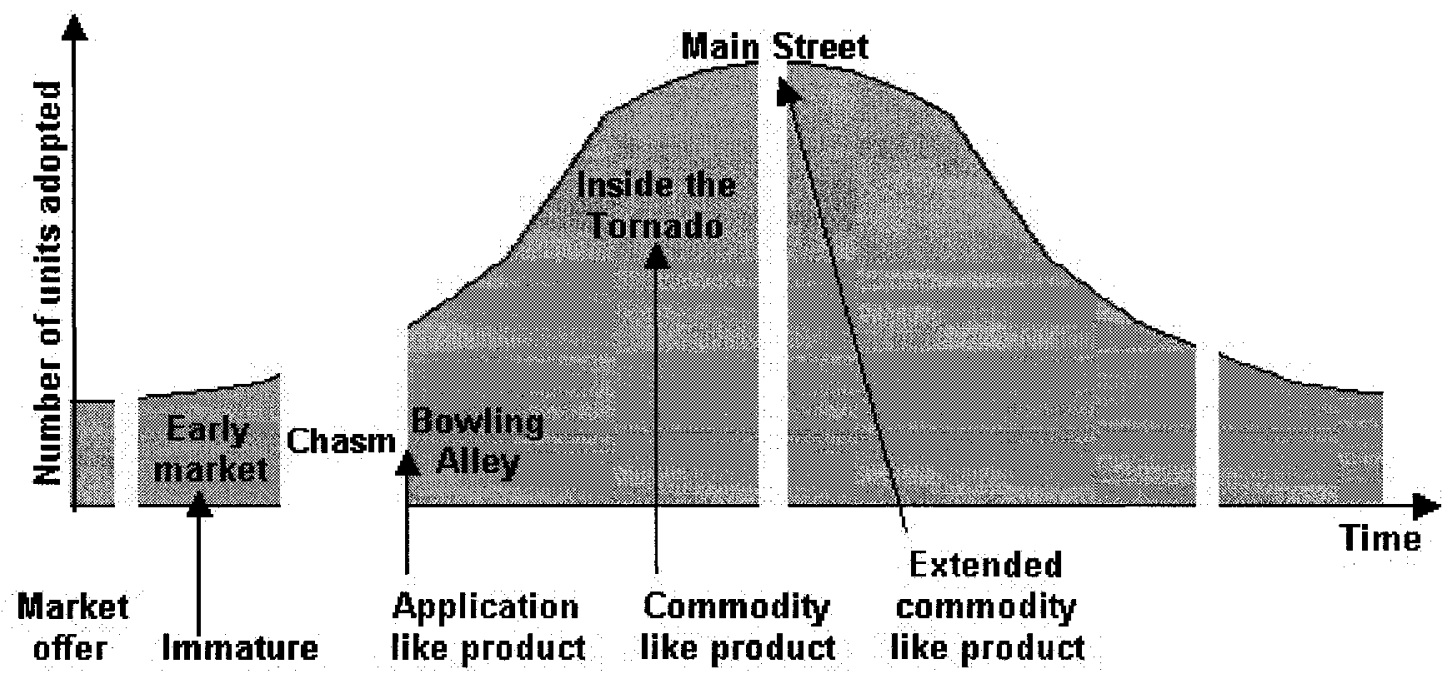




\subsubsection{Density-dependence model}

The density-dependence model explains why the adoption of new technologies, over time, usually follows an S-curve (Geroski, 2000). The adoption of new technology takes a long period of time, even when the adopters seem to obtain a benefit from it. The model is based on the forces of legitimation and competition, which help to establish the new technology and ultimately limit their take-up (Geroski, 2000).

In order to make the decision of adopting a new technology, the potential adopters of the new technology need to gain knowledge about it (to build up legitimation). The knowledge acquisition is considered legitimate if it comes from other users who have accumulated experience with the new technology. This knowledge transfer is known as word of mouth.

Although this knowledge transfer generates the S-curve, it does not explain the diffusion of an innovation from its origin, but from the point where the early users start using it. The knowledge transfer starts taking place some time after this point by word of mouth. The larger the number of early adopters, the faster the diffusion will be.

The current literature does not provide a method to identify when a new technology changes from one stage to another. 


\subsection{Segmentation of primary software markets}

IDC divides the software market in three primary markets: packaged application software, application development and deployment software, and system infrastructure software. Table 2 shows these primary markets and their corresponding software markets definition.

Table 2 IDC's primary markets and software markets definition

\begin{tabular}{|l|l|}
\hline \multicolumn{1}{|c|}{ Primary markets } & \multicolumn{1}{c|}{ Software markets } \\
\hline Packaged application software & Cross-industry applications \\
& $-\quad$ Enterprise resource management \\
& $\begin{array}{r}-\quad \text { Office and collaborative applications } \\
\text { Industry specific applications }\end{array}$ \\
\hline $\begin{array}{l}\text { Application development \& } \\
\text { deployment }\end{array}$ & Services supply chain vertical views \\
& Information access and delivery (IAD) \\
& Appormation and data management \\
& Application life-cycle management (ALM) \\
\hline Systems infrastructure software & Systems and network management \\
& Middleware and serverware, Security \\
& System-level and networking applications \\
\hline
\end{tabular}

(Toncheva et al., 2000) 
Table 3 shows IDC's 20 vertical markets organized into seven sectors of the economy

(Toncheva et al., 2002).

Table 3 Vertical markets by sector

\begin{tabular}{|l|l|}
\hline \multicolumn{1}{|c|}{ Sector } & \multicolumn{1}{c|}{ Vertical market } \\
\hline Finance & Banking, Financial services, Insurance \\
\hline Manufacturing & Discrete, Process, Automotive \\
\hline Infrastructure & $\begin{array}{l}\text { Transportation } \\
\text { Telecommunications } \\
\text { Broadcast and other communications } \\
\text { Utilities }\end{array}$ \\
\hline Reatil & Wholesale and retail \\
\hline Services & $\begin{array}{l}\text { Healtcare, Business, Legal } \\
\text { Other services }\end{array}$ \\
\hline Resource & $\begin{array}{l}\text { Mining } \\
\text { Agriculture / construction }\end{array}$ \\
\hline Public & $\begin{array}{l}\text { Government } \\
\text { Education }\end{array}$ \\
\hline Software & $\begin{array}{l}\text { Information access and delivery } \\
\text { Information and data management } \\
\text { Application design and construction tools } \\
\text { Application life cycle-management }\end{array}$ \\
\hline
\end{tabular}

(Extended from IDC's list)

In summary, the IDC segmentation helps to position the UML-based development tools within a specific software market and segment.

The vertical markets will help to categorize buyers of UML-based development tools. 


\subsection{Review of software taxonomy}

ICD's taxonomy for application design and construction tools, the area of interest for this research, includes five specific markets (Heiman, 2003):

- Unified development environments, also known as integrated development environments

- Third Generation Language (3GL) tools

- Software construction components

- Analysis, modeling, design, and construction tools

- Web site design/development tools

In summary, the taxonomy provided by IDC offers an initial point to identify if a product offering can be considered a UML-based development tool.

Table 4 shows, in a nutshell, all of IDC's taxonomy characteristics for application design and construction tools. 
Table 4 IDC's taxonomy for application design and construction tools

\begin{tabular}{|c|c|c|c|c|}
\hline 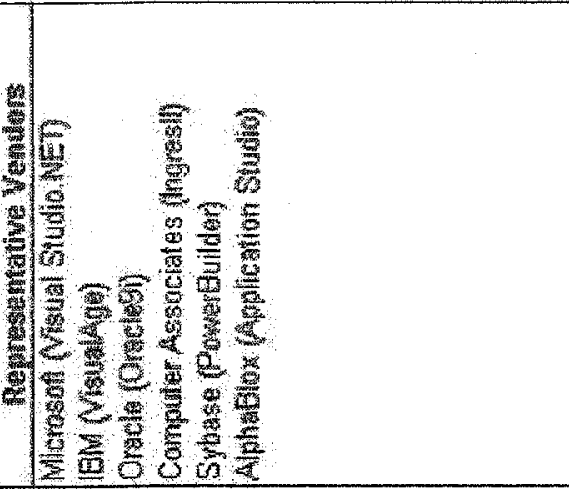 & 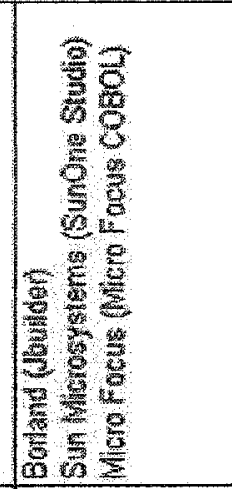 & 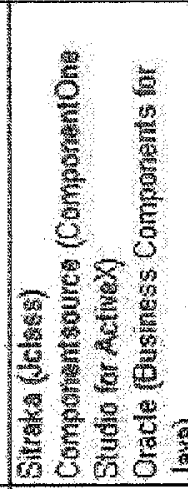 & 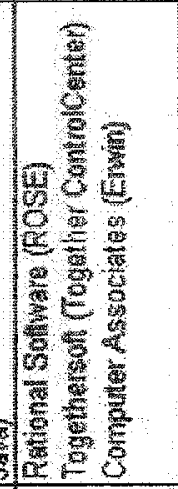 & 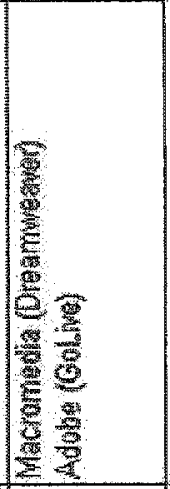 \\
\hline 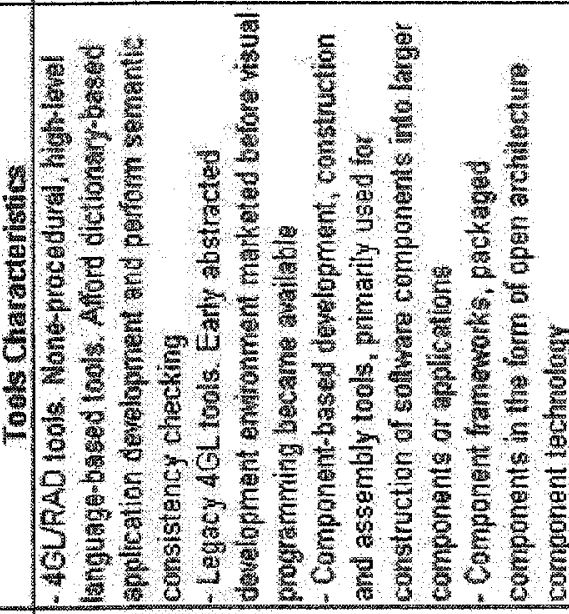 & 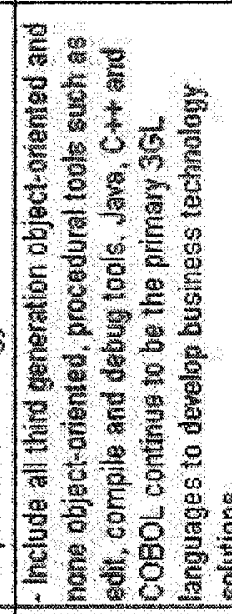 & 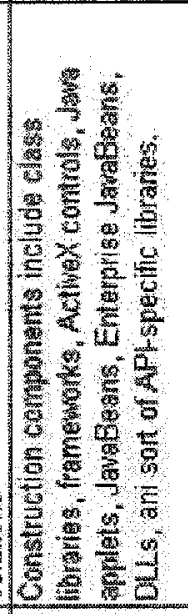 & 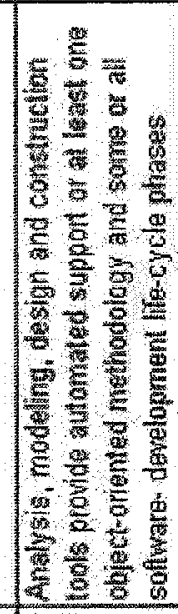 & 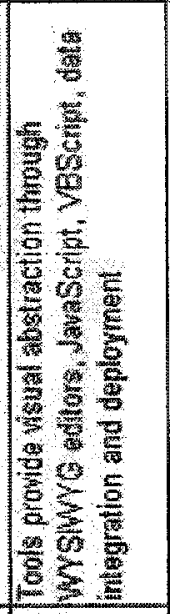 \\
\hline 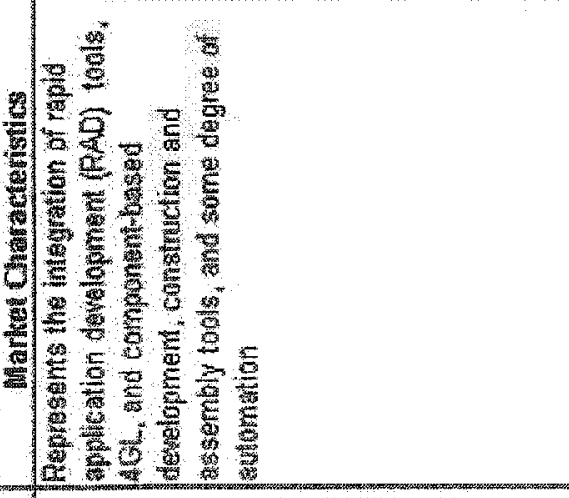 & 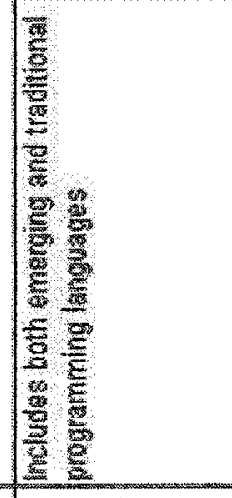 & 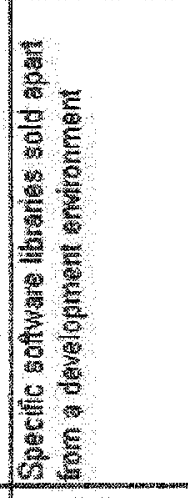 & 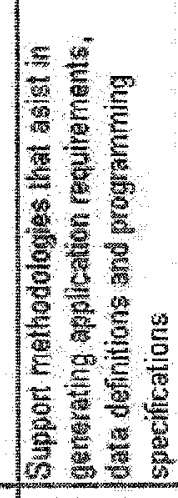 & 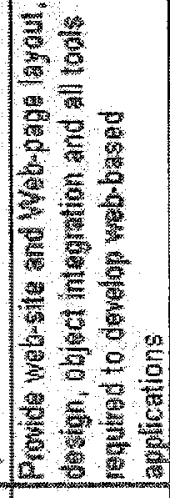 \\
\hline 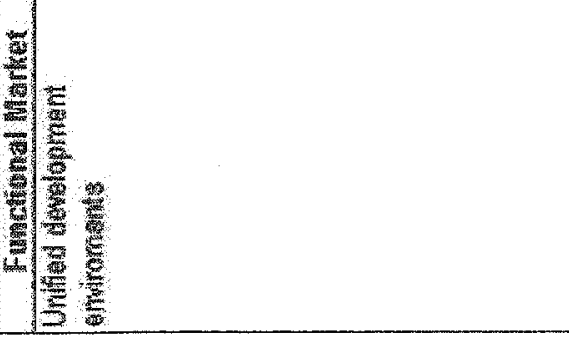 & $\frac{3}{8}$ & 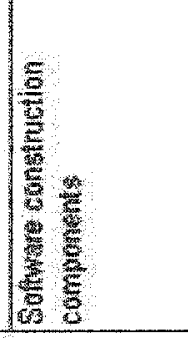 & 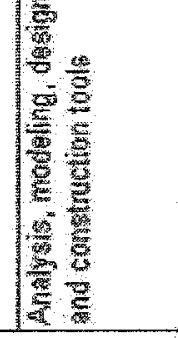 & 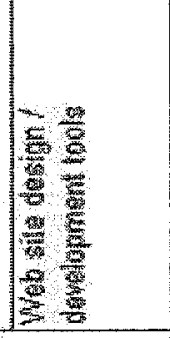 \\
\hline
\end{tabular}

(Heiman, 2003) 


\subsection{Lessons leared from reviewing the literature}

The unified modeling language is used as the foundation

The unified modeling language is used as the foundation of UML-based development tools. UML-based development tools exploit the benefits of using models. Tools can be classified based on the features offered. UML-based development tools can be classified on the following major categories: modeling-only, forward-engineering, reverse-engineering, round-trip engineering, and product-suite.

\section{There are four stages of technology adoption}

Moore (2002) identifies four stages of the technology adoption life-cycle: early market, crossing the chasm into the bowling alley, inside the tornado, and main street.

\section{Legitimateness and competitiveness drive the technology adoption}

The adoption of new technology follows an S-curve. This is explained by the densitydependence model, which combines the forces of the new technology legitimizing (recognition or credibility of the benefits of the new technology by the early adopters) and competition (Geroski, 2000).

\section{Classification of louyers' markets}

International Data Corporation (IDC), a well-recognized advisory firm, has a classification of 20 vertical markets organized into seven sectors of the economy. 
Lack of methods to identify stage transitions

There is no literature available that explains how to identify when a stage transition is occurring.

Lack of empirical research on reasons to commit to a technology

There is no literature related to the reasons for which suppliers and buyers commit to a new technology.

\section{Lack of empirical research on adoption of UML-based development tools}

There is no empirical research on either the adoption of UML-based development tools or on the temporal patterns of agents associated with UML-based development tools.

Identifying stage transitions and reasons to commit

Based on data gathered for the research, the researcher defines a way to:

- identify stage transitions using buyers' data

- identify suppliers' reasons to commit to UML-based development tools

- identify buyers' reasons to commit to UML-based development tools.

Stage transitions are defined using a method devised by Peng (2004) on Linux adoption by firms. 


\section{Hypotheses}

This chapter is divided into five sections. Section 3.1 develops the hypotheses to compare supplier and product attributes across adoption stages. Section 3.2 develops hypotheses to test temporal patterns of supplier and product diversity. Section 3.3 develops hypotheses to test temporal patterns of new suppliers and new buyers. Section 3.4 develops hypothesis to test supplier and buyer reasons to commit to UML-based development tools. Section 3.5 provides a list of the hypotheses.

\subsection{Comparing supplier and product attributes across adoption stages}

The first objective of this research is to measure the association between stages, buyers' and suppliers' attributes. The attributes of interest for this research are supplier size, supplier type, and product type.

Supplier size is used as a substitute for competence and financial means in empirical studies of technology diffusion (Geroski, 2000). The researcher expects that supplier size is a function of the adoption stage, therefore:

Ilypothesis 1: The size of a new supplier is a function of the adoption stage. 
Buyers' needs are different at each adoption stage (Moore, 2000). Organizations with diverse capabilities, needs, and goals will be willing to adopt the new technology at different times (Geroski, 2000). As buyers' needs change, the number and type of products offered by the suppliers change accordingly. It is expected that different product categories will be introduced at each stage, therefore:

Hypothesis 2: The type of a new product is a function of the adoption stage.

\subsection{Temporal patterns of supplier and product diversity}

The expected number of different product categories in the market for UML-based development tools is small. It includes modeling-only tools, reverse and forward-engineering tools, round-trip engineering tools, and product-suites.

It is expected that product diversity increases rapidly during the early adoption stages and then increases slowly during the final stages, therefore:

㳕ypothesis 3a: Product diversity increases rapidly during the early adoption stages and then increases slowly over the later stages.

Different supplier's types offer different product categories. Thus, supplier diversity and product diversity should behave in a similar way. It is expected that supplier diversity 
increases rapidly during the early adoption stages and then increases slowly during the later stages, therefore:

HIypothesis 3B: Supplier diversity increases rapidly during the early adoption stages and then increases slowly over the later stages.

Frequently, a new market is comprised of multiple customer niches. As the market matures, a mainstream market develops. Therefore, it is expected that customer diversity increases at the early adoption stages and then decreases during the later stages.

Hypothesis 3c. Buyer diversity increases rapidly during the early adoption stages and then increases slowly over the later stages.

\subsection{Temporal patterns of new suppliers and new buyers}

The density-dependence model holds that: (i) during the product legitimization period, the number of new suppliers grows rapidly, establishing a positive relationship with the number of new entrants per month and the number of cumulative firms committing to UML-based development tools; and (ii) during the competition period, this relationship switches to a negative one (Debackere and Clarysse, 1998).

Thus, the researcher expects that the number of new suppliers and buyers will follow a bellshape distribution, therefore: 
Hypothesis $4 a:$ New buyers' entry rate follows a bell-shape distribution.

Hypothesis 4b: New suppliers' entry rate follows a bell-shape distribution.

\subsection{Reasons for commitment}

Moore (2002) argues that customer needs are different at each adoption stage. While there is no empirical literature on whether the stage of adoption affects the reasons why suppliers and buyers commit to a particular technology, the researcher believes that the stage of the adoption cycle does affects the buyers' reasons for committing to UML-based development tools, therefore:

Hypothesis 5a: The reasons for which suppliers commit to UML-based development tools are a function of the adoption stage.

Hypothesis $\mathbf{5 b}$. The reasons for which buyers commit to UML-based development tools are a function of the adoption stage.

\subsection{List of hypotheses}

Hypothesis 1: The size of a new supplier is a function of the adoption stage.

Hypothesis 2: The type of a new product is a function of the adoption stage.

Hypothesis 3a: Product diversity increases rapidly during the early adoption stages then increases slowly over the later stages. 
Hypothesis $3 \mathrm{~b}$ : Supplier diversity increases rapidly during the early adoption stages and then increases slowly over the later stages.

Hypothesis 3c: Buyer diversity increases rapidly during the early adoption stages then increases slowly over the later stages.

Hypothesis 4a: New buyers' entry rate follows a bell-shape distribution.

Hypothesis $4 \mathrm{~b}$ : New suppliers' entry rate follows a bell-shape distribution.

Hypothesis 5a: The reasons for which suppliers commit to UML-based development tools are a function of the adoption stage.

Hypothesis 5b: The reasons for which buyers commit to UML-based development tools are a function of the adoption stage. 


\section{Research method}

\subsection{Unit of andingis}

The unit of analysis is an organization that made a commitment to offer or purchase a UMLbased development tool during the study period.

\subsection{Study period}

The study period is from January 1991, the month in which the first development environment that generated code out of a system model became available, to December 2003 , the month where data collection stopped. The study period includes 156 months.

\subsection{Sample}

The sample used in this research is comprised of all known suppliers and buyers that committed to UML-based development tools during the study period.

\subsubsection{Suppliers}

The following sources of information were used to identify suppliers of UML-based development tools:

- International Data Corporation (IDC) competitive analysis

- Business Source Premier database 
- OMG qualified service providers list

- Eclipse UML related plug-ins provider lists

- Google search engine

To identify suppliers of UML-based development tools using the Business Source Premiere database and the Google Web search engine, the following two strings were entered into the search engines: "model driven development" and "UML tools".

\subsubsection{Buyers}

The sample of buyers was obtained from examining news releases posted on suppliers' web sites and from reading news releases found in the Business Source Premier database. These news releases were found by performing queries searching for the supplier and product name.

\subsubsection{Products}

The sample of products was obtained from the websites of the suppliers in the sample. 


\subsection{Data collection}

\subsubsection{Company information}

Information on suppliers and buyers was obtained from companies' websites and the Business Source Premier database.

For each supplier, the following information was collected:

- Supplier name

- Revenue reported on the date closest to the first announcement

- Date on which revenue was reported

- Number of employees

- Number of product offerings

- Years of operation

For each buyer, the following information was collected:

- Buyer name

- Revenue reported on the date closest to the first announcement pertaining to the commitment to UML-based development tools

- Date on which revenue was reported

- Number of employees 


\subsubsection{Product categories}

UML-based development tools were classified into the following five product categories:

(i) Modeling-only. Tools that aid in the design and development of software models through visual modeling.

(ii) Reverse-engineering. Tools that enable UML visualization of source code.

(iii) Forward-engineering. Tools that generate source code out of a system model. This category could be subdivided based on the degrees of code generation (percentage of code generated). For the purpose of this research, the degree of code generation does not matter.

(iv) Round-trip engineering. Tools that provide forward and reverse-engineering.

(v) Product-suite. Tools that provide round-trip features and other features that might include requirements management, automated software verification, and defect tracking.

\subsubsection{Reasons for commitment}

The news releases published by suppliers and buyers were used to identify the reasons why suppliers and buyers committed to UML-based development tools.

Each news release pertaining to a tool sale or purchase contains one or more quotes from the supplier and/or the buyer. Each news release contains a quote from the supplier when the news release is related to the release of a new product.

For each news release, the buyers' and/or suppliers' quotes were analyzed and a set of short reasons for commitment descriptions was compiled. 


\subsubsection{Identifying adoption stages}

Stage transitions need to be identified to test hypotheses $1,2,3 a, 3 b, 3 c, 5 a$, and $5 b$. The researcher used the method devised by Peng (2004) to identify adoption stages. Adoption stages are based on changes on product diversity; the first stage starts when the first product type is introduced and ends when a new product type is introduced and so on.

This approach is based on insights from Rogers (1983), Moore (2002), and Geroski (2000). According to these researchers, buyers' needs are different at each stage of the technology adoption life-cycle, therefore the diversity of the products offered enabled by new technology changes over time. If product diversity is measured over time, then it can be used to mark the changes from one stage to the next. (Peng, 2004).

The criteria used to validate if a change in product diversity marked a change in stage comprise three factors; (i) change in product type, any change in product type marks a change in the diversity of the product, (ii) the length of time between stage transition, and (iii) the minimum percentage of buyers classified in a stage. The last two factors were required to avoid a large number of stages.

\subsubsection{Measurement of variables}

Number of new suppliers. Number of new suppliers for month $i$ is the sum of the companies that issued news releases announcing that they are developing or have introduced UML-based development tools during month $i$. 
Number of suppliers. Number of suppliers for month $i$ is the sum of the companies that issued news releases announcing that they are developing or have introduced UML-based development tools since the beginning of the study period minus the number of companies that have ceased to operate.

Number of new buyers. Number of new buyers for month $i$ is the sum of organizations that issued news releases announcing that customers have purchased UML-based development tools or services during month $i$.

Existing buyers that stop using UML-based development tools are not considered to reduce the sample.

Number of buyers. Number of buyers for month $i$ is the sum of the organizations that issued news releases announcing that customers have purchased UML-based development tools since the beginning of the study period minus the number of companies that have ceased to operate.

Suppliers' type. According to Malerba (2002), the agents can be companies or noncompanies (e.g., universities, financial institutions, govermments), as well as organizations at lower levels (e.g., application developers), or higher levels of aggregation (e.g., consortia). Suppliers that announced their commitment to UML-based development tools are classified into the following categories: 
- Independent sofware vendors (ISV)

- Open source software developers

- Universities

Number of new products. Number of new products for month $i$ is the sum of the new products introduced during month $i$

New versions of existing products are not considered new products unless the product name is different (e.g., Rational Rose and Rational Rose RealTime are considered different products).

Number of products. Number of products for month $i$ is the sum of new products introduced since the beginning of the study period minus the products that are no longer sold.

New Supplier and Supplier diversity. Diversity $=1-\Sigma\left(p_{i}\right)^{2}$

Where:

$i=$ supplier category

$p_{i}=$ percentage of suppliers in category $i$

New supplier diversity refers to the diversity of the suppliers that announced their commitment to UML-based development tools in month $i$. 
Supplier diversity refers to the diversity of the suppliers that announced their commitment to UML-based development tools from the beginning of the study period to the end of month $i$.

The minimum and maximum numbers that supplier diversity can take are zero and one respectively. A low diversity means that the number of suppliers offering UML-based development tools is low (e.g., under fifty percent of the supplier sample). A high diversity means that the number of suppliers offering UML-based development tools is high (e.g., fifty percent or more of the supplier sample).

Buyers" types. Buyers that announced their commitment to UML-based development were categorized into types using the $\mathrm{N}$ markets included in IDC's vertical market list (Toncheva, et al. 2002) and four additional markets identified by the researcher: information access and delivery, information and data management, application design and construction tools, and application life cycle management. Buyers were classified into the following buyer types:

- Banking

- Financial services

- Insurance

- Discrete manufacturing

- Process manufacturing

- Automotive manufacturing

- Transportation

- Broadcast and other communications
- Utilities

- Wholesale

- Retail

- Healtcare

- Business and legal

- Engineering / management

- Other services

- Mining

- Agriculture/ construction 
- Governmeñ

- Education

- Telecommunications

- Information access and delivery
- Information and data management

- Application design and construction tools

- Application life cycle-management

New Buyer and Buyer diversity. Diversity $=1-\Sigma\left(p_{j}\right)^{2}$

Where:

$j=$ buyer category

$p_{i}=$ percentage of suppliers in category $j$

New buyer diversity refers to the diversity of the suppliers that announced their commitment to UML-based development tools in month $j$.

Buyer diversity refers to the diversity of the suppliers that announced their commitment to UML-based development tools from the beginning of the study period to the end of month $j$. The minimum and maximum numbers that buyer diversity can take are zero and one respectively. A low diversity means that the number of buyers that acquired UML-based development tools is low (e.g., under fifty percent of the buyer sample). A high diversity means that the number of buyers that acquired UML-based development tools is high (e.g., fifty percent or more of the buyer sample).

Product category. This can be modeling-only, backward-engineering, forward-engineering, round-trip engineering, or product-suite as specified in section 4.4.2.1. 
Product diversidy. Diversity $=1-\Sigma\left(p_{k}\right)^{2}$

Where:

$k=$ product category

$p_{k}=$ percentage of products in category $k$

Product diversity refers to the diversity of the UML-based development tools products bought from the beginning of the study period.

The minimum and maximum numbers that product diversity can take are zero and one respectively. A low diversity means that the number of products that entered the UML-based development tools market is low (e.g., under fifty percent of the product sample). A high diversity means that the number of products that entered the UML-based development tools market is high (e.g., fifty percent or more of the supplier sample).

Buyer size. The number of employees and the annual revenue measure size. The data used was that which was reported at the date closest to the date (time $t$ ) in which the supplier or buyer entered the UML-based development tools market. Privately held organizations do not publish their annual revenue or number of employees. For the purpose of this research, private organizations are considered small.

Number of products the company introduced. This refers to the total number of products introduced during the study period. 
Size of the largest buyer. Size of the largest buyer at month $i$ is the largest amount of revenue generated by a supplier operating in month $i$.

Density. The cumulative number of firms that enter the UML-based development tools market minus the number of firms that stop operations or abandon the related business.

Density squared (DENSQ) $=($ Density * Density $) / 1000$ 


\section{Results}

\subsection{Sample}

\subsubsection{New suppliers}

The supplier sample was comprised of seventy companies. Appendix I provides the names of the seventy companies in the supplier sample.

Table 5 provides the number of suppliers of UML-based development tools identified by source of information. Examining six sources of information identified a total of 101 suppliers.

Table 6 shows that of the 101 suppliers identified from six sources of information, 12 were companies that were out of business and 19 were no longer offering UML-based development tools as of December 2003. Thus, the sample used for this research included seventy firms (101 - $12-19)$. 
Table 5 Number of suppliers identified by source of information

\begin{tabular}{|l|c|}
\hline \multicolumn{1}{|c|}{ Source } & $\begin{array}{c}\text { Number of suppliers of UML- } \\
\text { based development tools }\end{array}$ \\
\hline DC competitive analysis list & 19 \\
\hline Business Source Premier database search & 17 \\
\hline OMG list & 22 \\
\hline Eclipse UML-related providers list & 10 \\
\hline Objects by design web site list & 82 \\
\hline $\begin{array}{l}\text { Number of suppliers identified after } \\
\text { eliminating redundancy }\end{array}$ & 101 \\
\hline
\end{tabular}

Table 6 Number of suppliers in the sample

\begin{tabular}{|l|r|}
\hline Number of suppliers identified & 101 \\
\hline Number of suppliers that were out of business as of December 2003 & 12 \\
\hline $\begin{array}{l}\text { Number of suppliers that did not offer UML-based development tools } \\
\text { as of December 2003 }\end{array}$ & 19 \\
\hline Number of suppliers in the sample & 70 \\
\hline
\end{tabular}

Throughout section five, a series of descriptive statistics are presented. These statistics include values for skewness, the p-value for skewness, kurtosis, and the $p$-value for kurtosis.

Skewness is a measure of the symmetry of a distribution around its mean. Kurtosis is a measure of the peakness of a distribution. Table 7 shows the skewness interpretation. A low $p$-value indicates the skewness is significantly non-normal. Table 8 shows the Kurtosis interpretation. A low p-value indicates the kurtosis is significantly non-normal. The p-value expresses the probability of observing a sample as extreme (or more so) when the nullhypothesis is true. The smaller the p-value the more untenable the null-hypothesis is. 
Table 7 Skewness interpretation

\begin{tabular}{|c|l|}
\hline Skewness & \multicolumn{1}{|c|}{ Interpretation } \\
\hline$=0$ & Distribution is symmetrical about the mean \\
\hline$>0$ & Distribution has a right-tail skew - more observations in the left-tail than normal. \\
\hline$<0$ & Distribution has a left-tail skew - more observations in the right-tail than normal. \\
\hline
\end{tabular}

Table 8 Kurtosis interpretation

\begin{tabular}{|c|l|}
\hline Kurtosis & \multicolumn{1}{|c|}{ Interpretation } \\
\hline$=0$ & Distribution is normal \\
\hline$>0$ & $\begin{array}{l}\text { Distribution is more peaked than normal - more observations are clustered } \\
\text { around the mean, with fewer in the tails than normal. }\end{array}$ \\
\hline$<0$ & $\begin{array}{l}\text { Distribution is squatter than normal - more observations are in the tails, with less } \\
\text { clustered around the mean than normal. }\end{array}$ \\
\hline
\end{tabular}

\subsubsection{Suppliers descriptive statistics}

The research period has 156 months (from January 1991 to December 2003); thus, there are 156 observations of the variables entry rate, density, and supplier diversity. Table 9 shows the descriptive statistics of these variables. 
Table 9 Descriptive statistics for suppliers' entry rate density and diversity

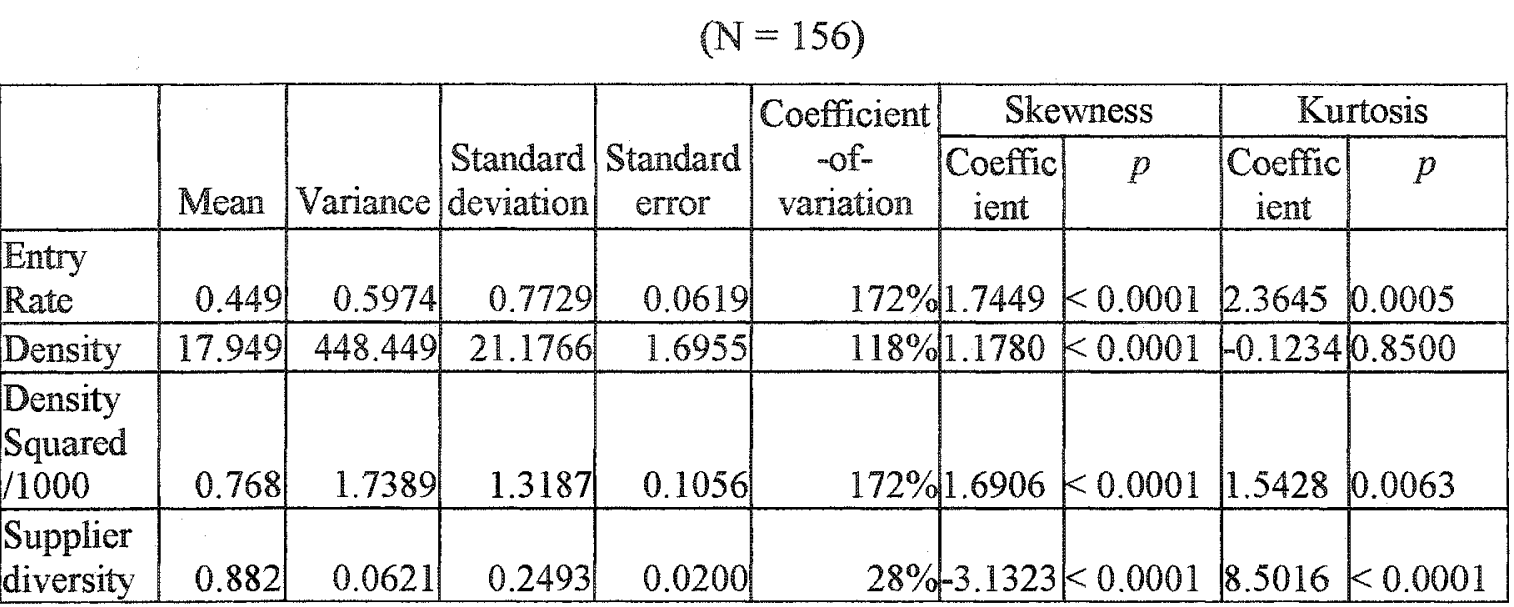

The suppliers' entry rate, density, and density squared/1000 have positive skewness coefficient indicating that the distribution is skewed to the right. Suppliers' diversity has a negative skewness coefficient indicating that the distribution is skewed to the left.

Figures 2 and 3 illustrate the supplier entry rate and the supplier density over the 156 months. Supplier density refers to the cumulative number of UML-based development tools suppliers at the end of the month. 
Tigure 2 Monthly supplier entry rate

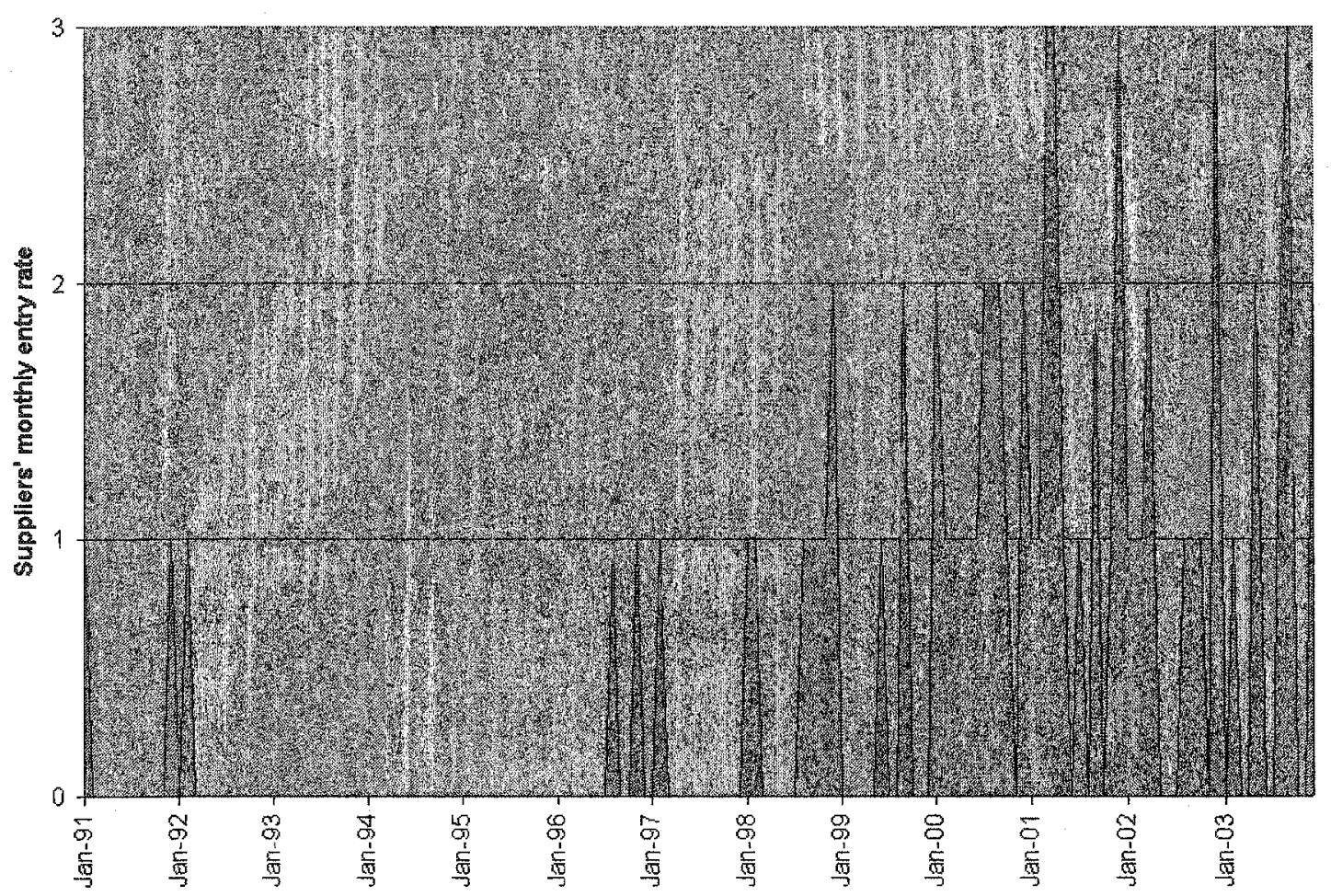

Figure 3 Supplier density

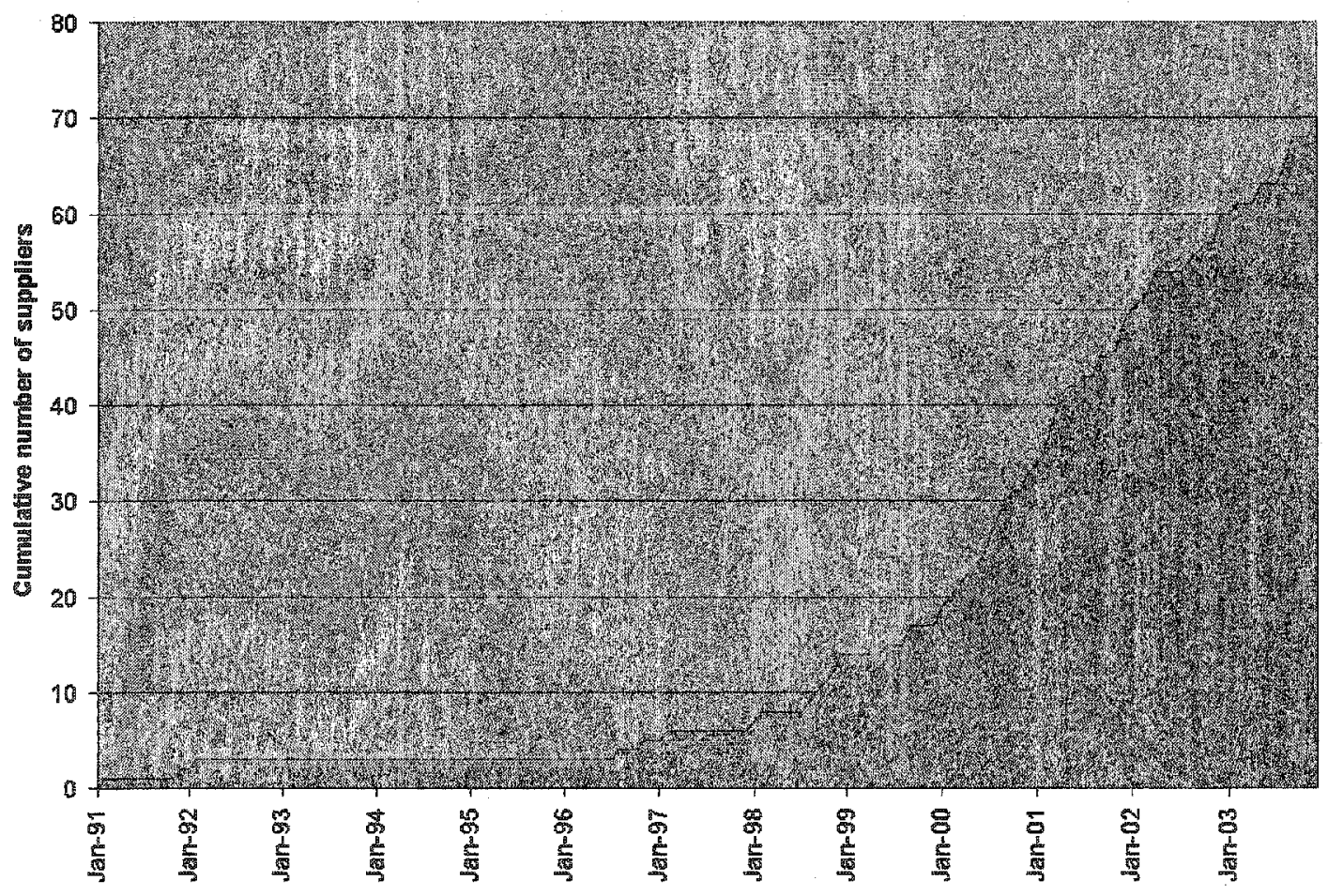




\subsubsection{Supplier types}

Table 10 provides the breakdown of the number of suppliers in the sample by supplier category. Table 10 indicates that independent software vendors account for $88 \%$ of the companies in the sample.

Table 10 Supplier category

\begin{tabular}{|l|r|r|}
\hline \multicolumn{1}{|c|}{ Supplier types } & Number & Percentage \\
\hline Independent sofware vendors & 61 & $87.14 \%$ \\
\hline Open Source & 8 & $11.43 \%$ \\
\hline University & 1 & $1.43 \%$ \\
\hline Totals & 101 & $100.00 \%$ \\
\hline
\end{tabular}

Figure 4 illustrates supplier diversity over the study period. 
Figure 4 Supplier diversity

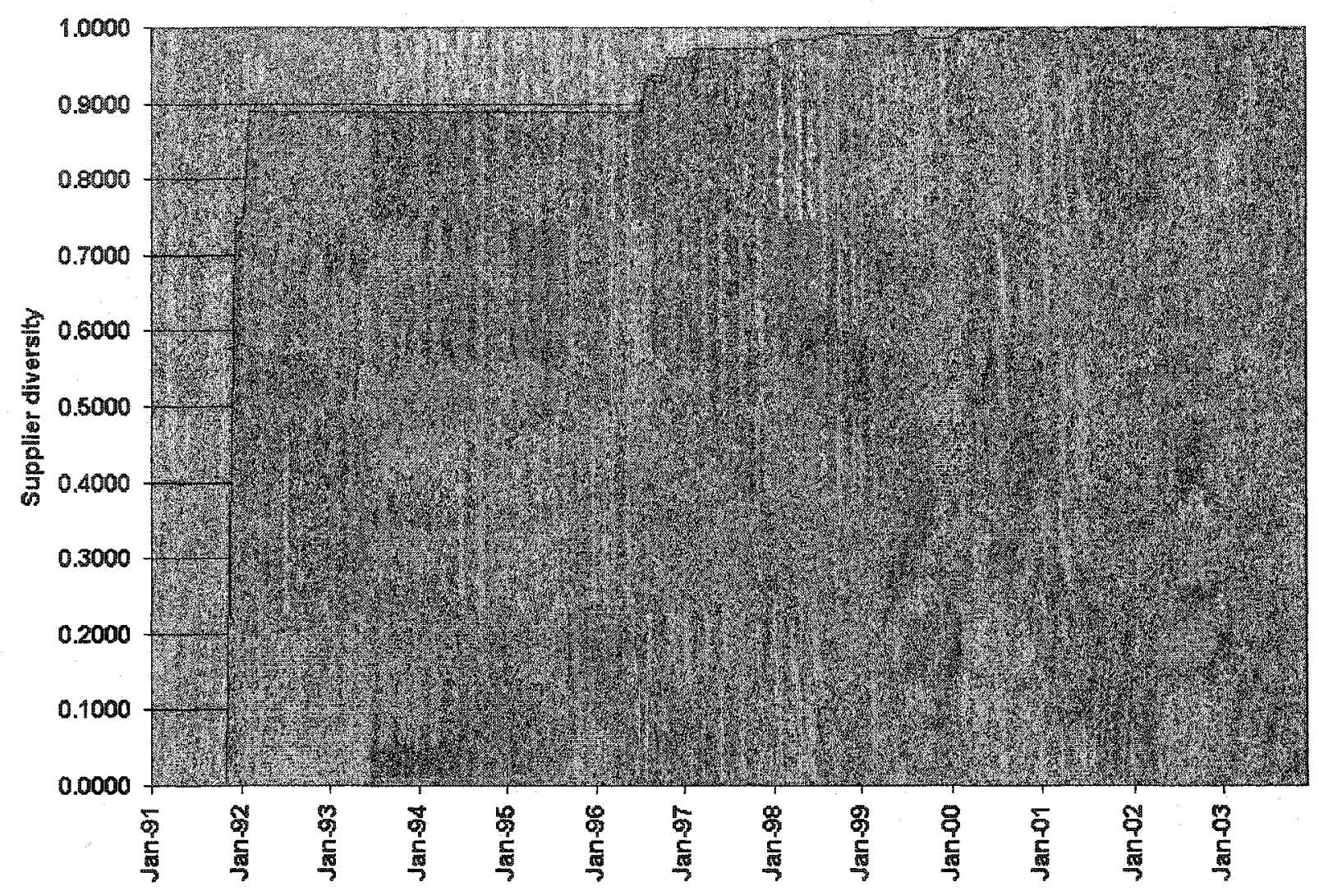

\subsubsection{Suppliers" annual revenue, age, and size}

Table 11 provides the descriptive statistics for suppliers' annual revenue, size, and age. The data was collected for the month in which the first product was introduced into the market. Many of the companies in the sample were private companies. Thus, revenue data for only 28 out of 70 suppliers was available and employee data for only 30 suppliers was available. Age was available for all 70 suppliers in the sample. 
Table 11 Descriptive statistics for supplier's annual revenue, size, and age

\begin{tabular}{|c|c|c|c|c|c|c|c|c|c|c|}
\hline & \multirow[b]{2}{*}{$\mathbf{n}$} & \multirow[b]{2}{*}{ Mean } & \multirow[b]{2}{*}{ Variance } & \multirow[b]{2}{*}{$\begin{array}{l}\text { Standard } \\
\text { deviation }\end{array}$} & \multirow[b]{2}{*}{$\begin{array}{l}\text { Standard } \\
\text { error }\end{array}$} & \multirow{2}{*}{$\begin{array}{c}\text { Coefficien } \\
\text { t-of- } \\
\text { variation }\end{array}$} & \multicolumn{2}{|c|}{ Skewness } & \multicolumn{2}{|c|}{ Kurtosis } \\
\hline & & & & & & & $\begin{array}{c}\text { Coeffici } \\
\text { ent }\end{array}$ & $p$ & $\begin{array}{c}\text { Coeffici } \\
\text { ent }\end{array}$ & $p$ \\
\hline Revenue & 28 & 21032.473 & 4267188079.562 & 65323.718 & 12345.022 & $311 \%$ & 3.5379 & K & 12.6804 & k 0.0001 \\
\hline Size & 30 & 13947.800 & 2232556504.441 & 47249.937 & 8626.619 & $339 \%$ & 4.9197 & $\begin{array}{l}\sigma_{0} \\
0.0001\end{array}$ & 25.4980 & $\begin{array}{l}k \\
0.0001\end{array}$ \\
\hline Age & 70 & 12.400 & 137.490 & 11.726 & 1.401 & $95 \%$ & 2.9612 & K & 14.8826 & $<$ \\
\hline
\end{tabular}

The supplier's revenue, size, and age have a positive skewness coefficient indicating that the distributions are skewed to the right.

Figure 5 shows the histograms for suppliers' annual revenue (millions), age (years), and number of employees. The majority of suppliers are small and young companies with revenue under US $\$ 100$ million.

\section{Figure 5 Histogram for suppliers' annual revenue, age, and number of employees}

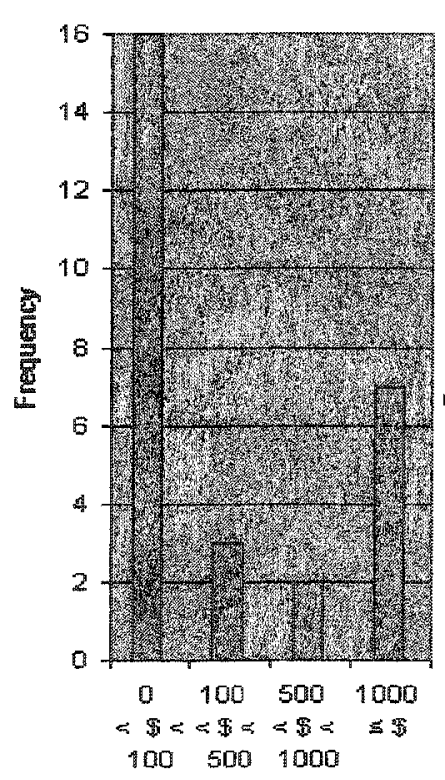

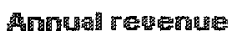
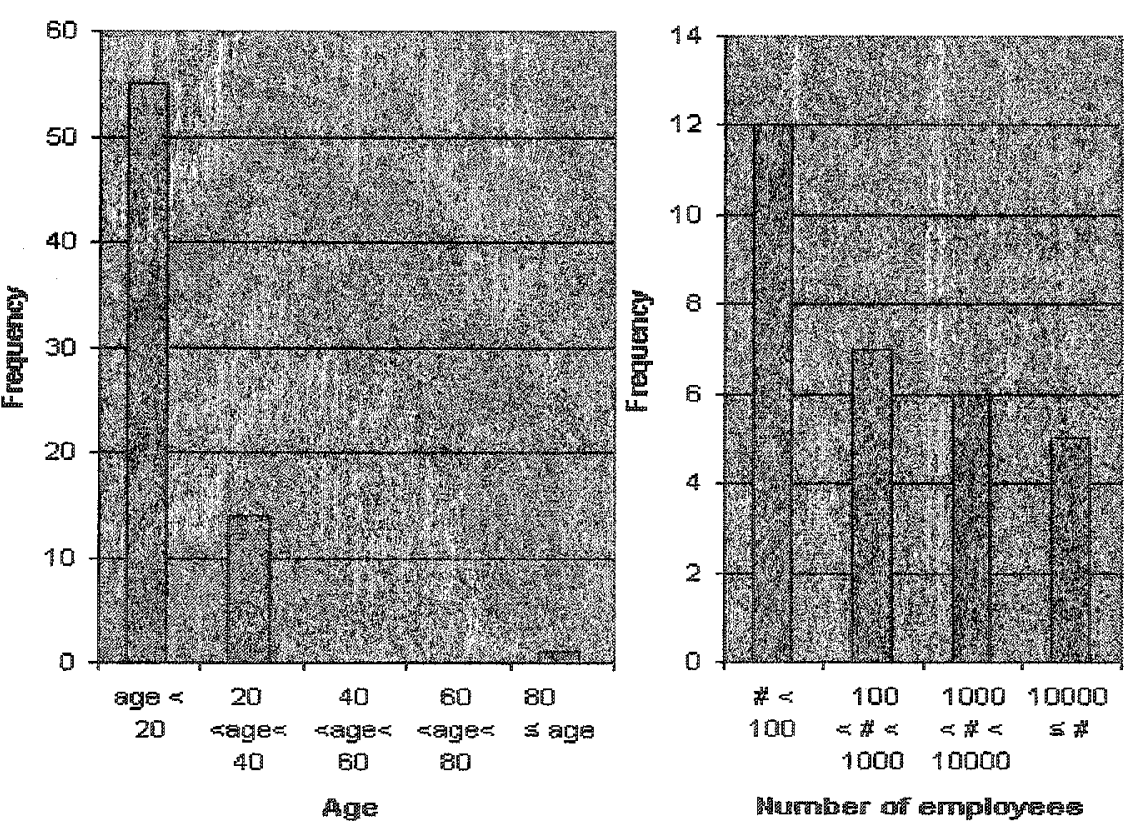

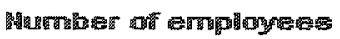




\subsection{New buyers}

The buyer sample was comprised of 53 companies. Appendix II provides the names of the 53 companies in the buyer sample.

Examining suppliers' news releases identified the 53 buyers. The suppliers' news releases included the name of the buyer. Thus, the sample used for the research included 53 buyers. Error is introduced due to the fact that many buyers are not identified possibly because they did not want to be reveled.

Table 12 shows the descriptive statistics for the buyer sample. 
Table 12 Descriptive statistics for buyers' entry rate, density and diversity

\begin{tabular}{|l|c|c|c|c|c|c|c|c|c|}
\hline & & & $\begin{array}{c}\text { Standard } \\
\text { deviation }\end{array}$ & $\begin{array}{c}\text { Standard } \\
\text { error }\end{array}$ & $\begin{array}{c}\text { Coefficient } \\
\text { of-variation }\end{array}$ & $\begin{array}{c}\text { Coeffici } \\
\text { ent }\end{array}$ & $p$ & $\begin{array}{c}\text { Coeffici } \\
\text { ent }\end{array}$ & $p$ \\
\hline $\begin{array}{l}\text { Entry } \\
\text { Rate }\end{array}$ & 0.38000 & 1.16600 & 1.08000 & 0.08600 & $285 \%$ & 3.6221 & $<0.0001$ & 14.3396 & $<0.0001$ \\
\hline Density & 5.69000 & 171.67200 & 13.10200 & 1.04900 & $230 \%$ & 2.6483 & $<0.0001$ & 6.1987 & $<0.0001$ \\
\hline $\begin{array}{l}\text { Density } \\
\text { Squared } \\
\text { /1000 }\end{array}$ & 0.20300 & 0.38934 & 0.62397 & 0.04996 & $307 \%$ & 3.6859 & $<0.0001$ & 13.9086 & $<0.0001$ \\
\hline $\begin{array}{l}\text { Supplicr } \\
\text { diversity }\end{array}$ & 0.28973 & 0.19661 & 0.44341 & 0.03550 & $153 \% 0.8852$ & $<0.0001$ & -1.2188 & $<0.0001$ \\
\hline
\end{tabular}

Figure 6 shows the buyer entry rate. Buying activity starts in September 1999, stops for almost a year and starts again in June 2001. Beginning in January 2002, the number of buyers increases steadily.

Figure 7 shows the buyer density following the same pattern as the supplier and product diversity. 
Tigure 6 New buyers entry rate

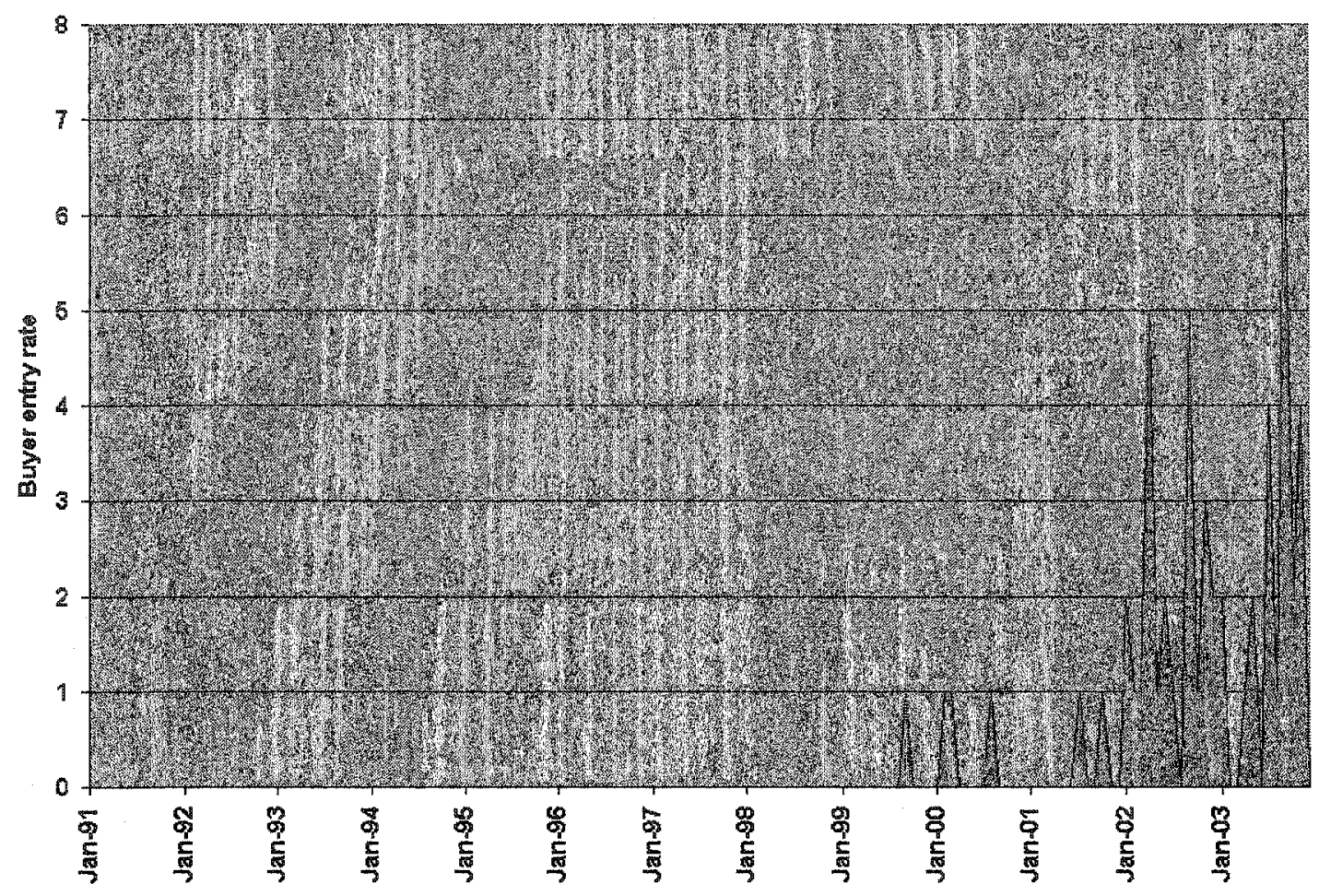

Figure 7 New buyers density

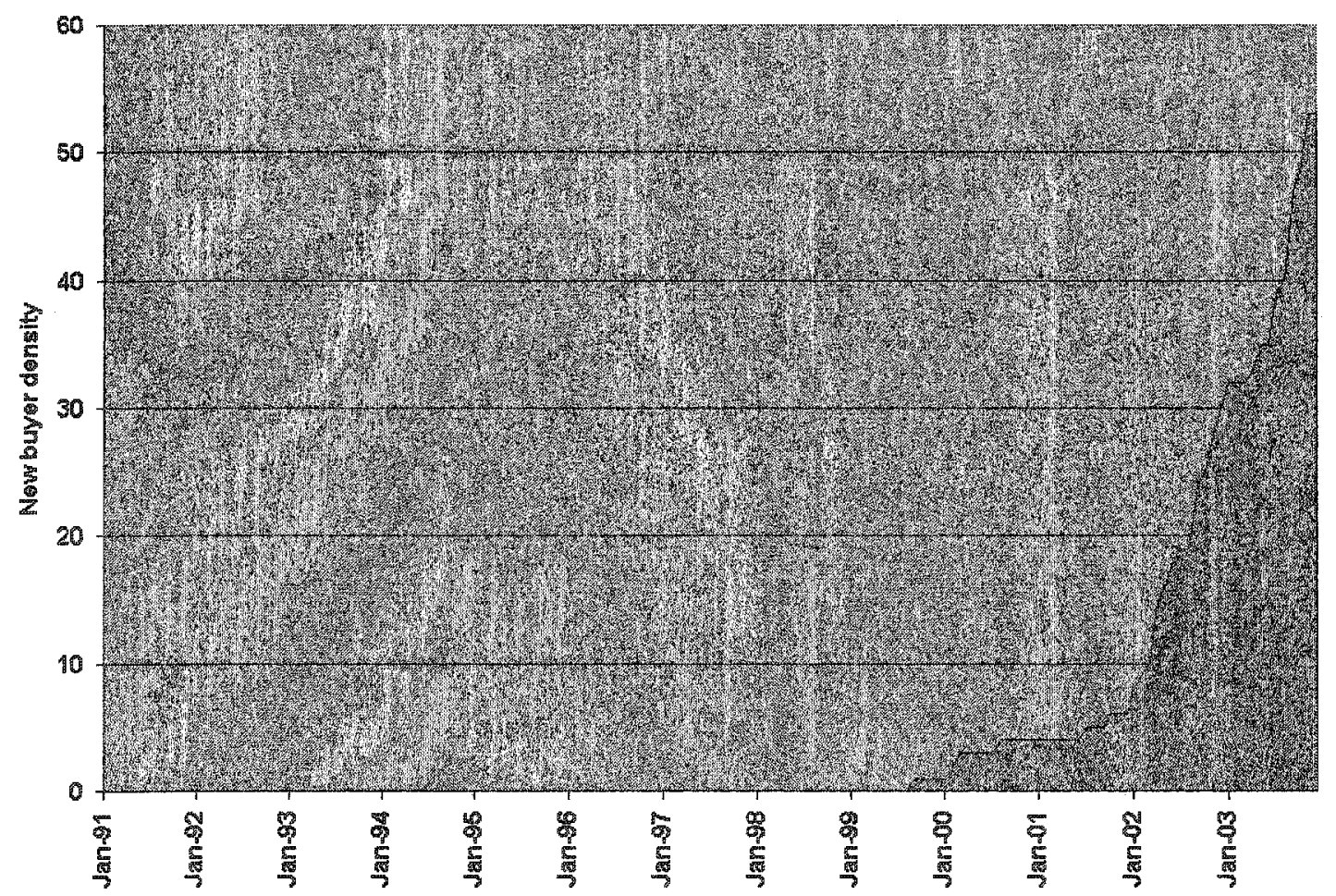




\subsection{Adoption stages}

Buyer data is used to define when a change in adoption stage occurs. The changes in adoption stages were identified using the criteria described in section 4.4.4. A stage begins when all of the following criteria are met:

- a new product type is introduced by a supplier

- at least five percent of the buyer sample are classified as users of the stage and product type

- the last stage change occurred at least 12 months ago

The last two conditions are used to reduce the number of potential stage transitions during periods where many changes in product diversity occur within short periods of time.

\subsubsection{Changes in product types identified from buyers' data}

Based on the criteria to define adoption stages, the researcher used data from news releases to identify all the potential changes in adoption stages.

On September 1999 the initial state transition is defined by the first integration of two products, a forward-engineering tool from Visible Systems and a software repository to allow software development teams simultaneously to share and manage their designs.

The next potential state transition is in February 2000 when Matra Marconi Space purchased ObjectGeode product suite to provide a dynamic description of the sofware's behavior and 
strengthened the developers' and customers' confidence in the design's robustness. Product type transitions from forward engineering to product-suite.

The next potential stage transition is in March 2000 when Lucent Technologies Inc. acquired RapidRMA modeling software to describe the data flow of its next generation systems prior to system completion. Product type change from product-suite to modeling-only.

The next potential stage transition is in August 2000 when the Northern Alberta Institute of Technology purchased over 150 licenses of Visual UML 2.5 to equip its computer systems technology program training labs. Product type transitions from modeling-only to round-trip engineering.

The next potential stage transition is in October 2001, when Broadband storage acquired System Architect from Popkin Software to manage the design of their software and systems in a real-time, high-performance embedded environment. With this transaction, six percent of the buyer sample is classified as user of the product-suit type, ten percent of the sample is classified within stage 1, and the last stage transition occurred twelve months or more before. All three conditions for a valid stage transitions are met; therefore this is a valid stage transition.

The next potential stage transition is in January 2002 when Dell Computer Corporation standardized on Visual UML and purchased an unlimited user site license for widespread 
deployment and use throughout Dell EMEA (Europe, Middle East, Africa) division. With this transaction, six percent of the buyer sample is classified as user of the round-trip engineering product type. However it is less than twelve months after the previous stage transition.

The next potential stage transition is in June 2002 when Kennedy Carter consultants took the concept to a fully developed product achieving $100 \%$ automated Ada 95 code generation for BAE Systems. With this transaction six percent, of the buyer sample is classified as user of the forward-engineering product type. However it is less than twelve months after the previous stage transition.

The next potential stage transition is in October 2002 when Conti Temic Microelectronic GmbH acquired Statemate Rhapsody to allow them to 'feel' the systems behavior, make changes on the fly, validate their design, generate code, and conduct tests much more quickly. At this point, at least five percent of the buyers sample is classified on each of the product types, there is a period of at least twelve months from the previous stage transition, and at least five percent of the buyer sample is classified in the current stage; therefore this is a valid stage transition.

The final potential stage transition is in October 2003 when the Arizona Supreme Court in Phoenix acquired Visible Developer to allow their development teams to quickly produce well architected. NET solutions. At this point, at least five percent of the buyers sample is 
classified on each of the product types, there is a period of at least twelve months from the previous stage transition, and at least five percent of the buyer sample is classified in the current stage; therefore this is a valid stage transition. Table 13 shows all potential adoption stage transitions identified from buyers' data.

Table 13 Potential stage transitions identified from buyers' data

\begin{tabular}{|c|c|c|c|c|}
\hline Date & Buyer & Buyer vertical market & Product type & $\begin{array}{c}\text { Stage } \\
\text { transition }\end{array}$ \\
\hline Sep/1999 & Visible Systems & $\begin{array}{l}\text { Application design and } \\
\text { construction tools }\end{array}$ & $\begin{array}{l}\text { Forward- } \\
\text { engineering }\end{array}$ & $\begin{array}{c}\text { First } \\
\text { stage } \\
\text { transition }\end{array}$ \\
\hline Feb/2000 & $\begin{array}{l}\text { Matra Marconi } \\
\text { Space }\end{array}$ & Transportation & Product suite & No \\
\hline Mar/2000 & $\begin{array}{l}\text { Lucent } \\
\text { Technologies Inc. }\end{array}$ & Telecommunications & $\begin{array}{l}\text { Modeling- } \\
\text { only }\end{array}$ & No \\
\hline Aug/2000 & $\begin{array}{l}\text { Northern Alberta } \\
\text { Institute of } \\
\text { Technology }\end{array}$ & Education & $\begin{array}{l}\text { Round-trip } \\
\text { engineering }\end{array}$ & No \\
\hline Oct $/ 2001$ & Broadband storage & Other services & Product suite & Yes \\
\hline $\mathrm{Jan} / 2002$ & $\begin{array}{l}\text { Dell Computer } \\
\text { Corp. }\end{array}$ & Discrete manufacturing & $\begin{array}{l}\text { Round-trip } \\
\text { engineering }\end{array}$ & No \\
\hline $\operatorname{Jun} / 2002$ & BAE Systems & Other services & $\begin{array}{l}\text { Forward- } \\
\text { engineering }\end{array}$ & No \\
\hline Oct $/ 2002$ & $\begin{array}{l}\text { Conti Temic } \\
\text { Microelectronic } \\
\text { GmbH }\end{array}$ & Discrete manufacturing & Product suite & Yes \\
\hline $0 \mathrm{ct} / 2003$ & $\begin{array}{l}\text { Arizona Supreme } \\
\text { Court in Phoenix }\end{array}$ & Government & $\begin{array}{l}\text { Modeling } \\
\text { only }\end{array}$ & Yes \\
\hline
\end{tabular}

Table 14 shows the percentage of buyers classified in each of the product types and potential stages identified on Table 13. 
Table 14 Percent of buyers by product type and potential stage

\begin{tabular}{|c|c|c|c|c|c|c|c|}
\hline 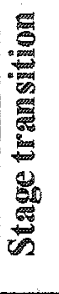 & $\begin{array}{l}\text { Year } \\
\text { and } \\
\text { month } \\
\text { stage } \\
\text { started }\end{array}$ & $\begin{array}{l}\text { Percent of } \\
\text { buyer } \\
\text { sample in } \\
\text { modeling- } \\
\text { only }\end{array}$ & $\begin{array}{l}\text { Dercent of } \\
\text { buyer sample } \\
\text { in forward- } \\
\text { engineering }\end{array}$ & $\begin{array}{c}\text { Percent of } \\
\text { buyer sample } \\
\text { in reverse- } \\
\text { engineering }\end{array}$ & $\begin{array}{l}\text { Peraent } \\
\text { of buyer } \\
\text { sempule in } \\
\text { product- } \\
\text { suite }\end{array}$ & $\begin{array}{l}\text { Percent } \\
\text { of buyer } \\
\text { sample in } \\
\text { stage }\end{array}$ & $\begin{array}{l}\text { Cammulative } \\
\text { percent of } \\
\text { buyer sample }\end{array}$ \\
\hline 1 & $\begin{array}{l}\text { Sep - } \\
1999\end{array}$ & $0 \%$ & $1.69 \%$ & $0 \%$ & $0 \%$ & $1.69 \%$ & $1.69 \%$ \\
\hline 2 & $\begin{array}{l}\text { Feb- } \\
2000\end{array}$ & $0 \%$ & $1.69 \%$ & $0 \%$ & $1.69 \%$ & $1.69 \%$ & $3.39 \%$ \\
\hline 3 & $\begin{array}{l}\text { Mar - } \\
2000\end{array}$ & $1.69 \%$ & $1.69 \%$ & $0 \%$ & $1.69 \%$ & $1.69 \%$ & $5.08 \%$ \\
\hline 4 & $\begin{array}{l}\text { Aug - } \\
2000\end{array}$ & $1.69 \%$ & $1.69 \%$ & $1.69 \%$ & $1.69 \%$ & $6.76 \%$ & $10.17 \%$ \\
\hline $\mathbf{5}$ & $\begin{array}{l}\text { Oct - } \\
2001\end{array}$ & $1.69 \%$ & $1.69 \%$ & $3.39 \%$ & $5.08 \%$ & $11.86 \%$ & $11.86 \%$ \\
\hline 6 & $\begin{array}{l}\text { Jan - } \\
2002\end{array}$ & $1.69 \%$ & $1.69 \%$ & $5.08 \%$ & $5.08 \%$ & $13.54 \%$ & $28.81 \%$ \\
\hline 7 & $\begin{array}{l}\text { Jun - } \\
2002\end{array}$ & $3.39 \%$ & $5.08 \%$ & $8.47 \%$ & $13.56 \%$ & $30.5 \%$ & $42.37 \%$ \\
\hline 8 & $\begin{array}{l}\text { Oct - } \\
2002\end{array}$ & $8.47 \%$ & $6.78 \%$ & $11.86 \%$ & $16.95 \%$ & $44.06 \%$ & $89.83 \%$ \\
\hline 9 & $\begin{array}{l}\text { Oct - } \\
2003\end{array}$ & $18.64 \%$ & $13.56 \%$ & $15.25 \%$ & $44.07 \%$ & $10.77 \%$ & $100.00 \%$ \\
\hline
\end{tabular}

Table 14 shows that some of the stages include less than five percent of the buyer sample and the number of months between stage transitions is less than twelve months. Stage 1 is considered to be before the first stage transition, from January 1991 to August 1998. For this reason, stages $1,2,3$, and 4 are consolidated into stage 2 . Stages 6 and 7 are consolidated into stage 3 , and stage 9 becomes stage 4 .

The four stages used to test hypotheses $1,2 a, 2 b, 3 a, 3 b, 5 a$, and $5 b$ are shown in Table 15 . 
Table 15 Adoption stages by product acquired

\begin{tabular}{|c|c|c|c|c|c|c|c|}
\hline 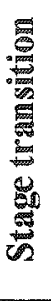 & $\begin{array}{l}\text { Year } \\
\text { and } \\
\text { month } \\
\text { stage } \\
\text { started }\end{array}$ & $\begin{array}{l}\text { Percente of } \\
\text { buyer } \\
\text { sample in } \\
\text { modeling- } \\
\text { only }\end{array}$ & $\begin{array}{l}\text { Percent of } \\
\text { buyer sample } \\
\text { in forward- } \\
\text { engineering }\end{array}$ & $\begin{array}{c}\text { Percent of } \\
\text { buyer sample } \\
\text { in reverse- } \\
\text { engineering }\end{array}$ & $\begin{array}{l}\text { Percent } \\
\text { of buyer } \\
\text { sample in } \\
\text { product- } \\
\text { suite }\end{array}$ & $\begin{array}{l}\text { Perecent } \\
\text { of buyer } \\
\text { sample in } \\
\text { stage }\end{array}$ & $\begin{array}{l}\text { Cumalative } \\
\text { percent of } \\
\text { buyer sample }\end{array}$ \\
\hline 1 & $\begin{array}{l}\text { Jan - } \\
1991\end{array}$ & $0.0 \%$ & $0.0 \%$ & $0.0 \%$ & $0.0 \%$ & $10.1 \%$ & $10.1 \%$ \\
\hline 2 & $\begin{array}{l}\text { Sep - } \\
1999\end{array}$ & $9.1 \%$ & $10.0 \%$ & $12.5 \%$ & $8.3 \%$ & $32.2 \%$ & $42.4 \%$ \\
\hline 3 & $\begin{array}{l}\text { Oct - } \\
2001\end{array}$ & $36.4 \%$ & $30.0 \%$ & $62.5 \%$ & $29.2 \%$ & $47.5 \%$ & $89.8 \%$ \\
\hline 4 & $\begin{array}{l}\text { Oct - } \\
2002\end{array}$ & $55.5 \%$ & $60.0 \%$ & $25.0 \%$ & $62.5 \%$ & $10.2 \%$ & $100.0 \%$ \\
\hline
\end{tabular}

\subsection{Testing hypothesis 1}

Hypothesis 1: The size of new supplier is a function of the adoption stage, was used to test the association between the supplier size (measured in revenue) and the adoption stage. Revenue data was obtained for only 28 of the 70 suppliers.

Table 16 shows the results of using the Mann-Whitney $U$ test to compare the suppliers' revenue at stages 1 and 2 . The results indicate that the mean rank of the supplier size at stage 1 is significantly larger than that at stage 2 . 
Table 16 Mann-Whitney U Test comparing suppliers' size between stages

$$
\begin{array}{r|rr}
\text { Alternative hypothesis } & \text { Supplier size by stage: Stage } 1 \neq \text { Stage } 2 \\
\mathrm{n} & 23 & \text { (cases excluded: } 33 \text { due to missing values) }
\end{array}
$$

\begin{tabular}{r|r|r|r|r} 
Supplier revenue by stage & \multicolumn{1}{|c|}{$\mathrm{n}$} & Rank sum & Mean rank & \multicolumn{1}{c}{$\mathrm{U}$} \\
\hline Stage 1 & 20 & 252.0 & 12.60 & 18.0 \\
Stage 2 & 3 & 24.0 & 8.00 & 42.0
\end{tabular}

\begin{tabular}{r|} 
Difference between \\
medians
\end{tabular} \mid$-\quad$

\begin{tabular}{r|rr} 
Mann-Whitney U statistic & 18 & \\
2 -tailed $p$ & 0.1846 & (normal approximation, corrected for ties)
\end{tabular}

Appendix III provides the Mann-Whitney $U$ tests for the remaining pairs of stages. The results of all Mann-Whitney $U$ tests show the following results:

- Suppliers entering the UML-based development tools market at stage 1 are significantly larger than those entering the market at stage 2 .

- Suppliers entering the UML-based development tools market at stage 2 are significantly smaller than those entering the market at stage 3 .

- Suppliers entering the UML-based development tools market at stage 3 are significantly smaller than those entering the market at stage 4.

The results support the acceptance of hypothesis 1 , suggesting that there is an association between the suppliers' size (revenue) and the adoption stage. However, this association weakens as the adoption process advances. 


\subsection{Products \$ample}

A total of 89 products were identified from the suppliers' web sites. Appendix IV shows the 89 products in the sample, the name of their suppliers, and the corresponding product category.

Table 17 shows the descriptive statistics for the product sample.

Table 17 Descriptive statistics for variables that describe the characteristics of products

$$
(\mathrm{N}=156)
$$

\begin{tabular}{|c|c|c|c|c|c|c|c|c|c|}
\hline & \multirow[b]{2}{*}{ Mean } & \multirow[b]{2}{*}{ Variance } & \multirow[b]{2}{*}{$\begin{array}{l}\text { Standard } \\
\text { deviation }\end{array}$} & \multirow[b]{2}{*}{$\begin{array}{l}\text { Standard } \\
\text { error }\end{array}$} & \multirow[b]{2}{*}{$\begin{array}{l}\text { Coefficient- } \\
\text { of-variation }\end{array}$} & \multicolumn{2}{|c|}{ Skewness } & \multicolumn{2}{|c|}{ Kurtosis } \\
\hline & & & & & & $\begin{array}{c}\text { Coeffici } \\
\text { ent }\end{array}$ & $p$ & $\begin{array}{c}\text { Coeffici } \\
\text { ent }\end{array}$ & $p$ \\
\hline $\begin{array}{l}\text { Entry } \\
\text { Rate }\end{array}$ & 0.5700 & 0.85300 & 0.92400 & 0.07400 & $162 \%$ & 1.8060 & $<0.0001$ & 3.0177 & $<0.0001$ \\
\hline Density & 22.2700 & 612.97200 & 24.75800 & 1.98200 & $111 \%$ & 1.1704 & $<0.0001$ & 0.0581 & 0.7525 \\
\hline $\begin{array}{l}\text { Density } \\
\text { Squared } \\
/ 1000\end{array}$ & 1.1050 & 3.53100 & 1.87915 & 0.15045 & $170 \%$ & 1.8885 & $<0.0001$ & 2.7082 & 0.0002 \\
\hline $\begin{array}{l}\text { Product } \\
\text { diversity }\end{array}$ & 0.8903 & 0.06361 & 0.25222 & 0.02019 & $28 \%$ & -3.1185 & $<0.0001$ & 8.4149 & $<0.0001$ \\
\hline
\end{tabular}

The product's entry rate, density, and density squared/1000 have positive skewness coefficients indicating that the distributions are skewed to the right. Product diversity has a negative skewness coefficient indicating that the distribution is skewed to the left. This means that product diversity has higher values at the end of the study period.

Figure 8 shows the monthly new product entry rate and stage transitions. 
Tigure 8 New product entry rone

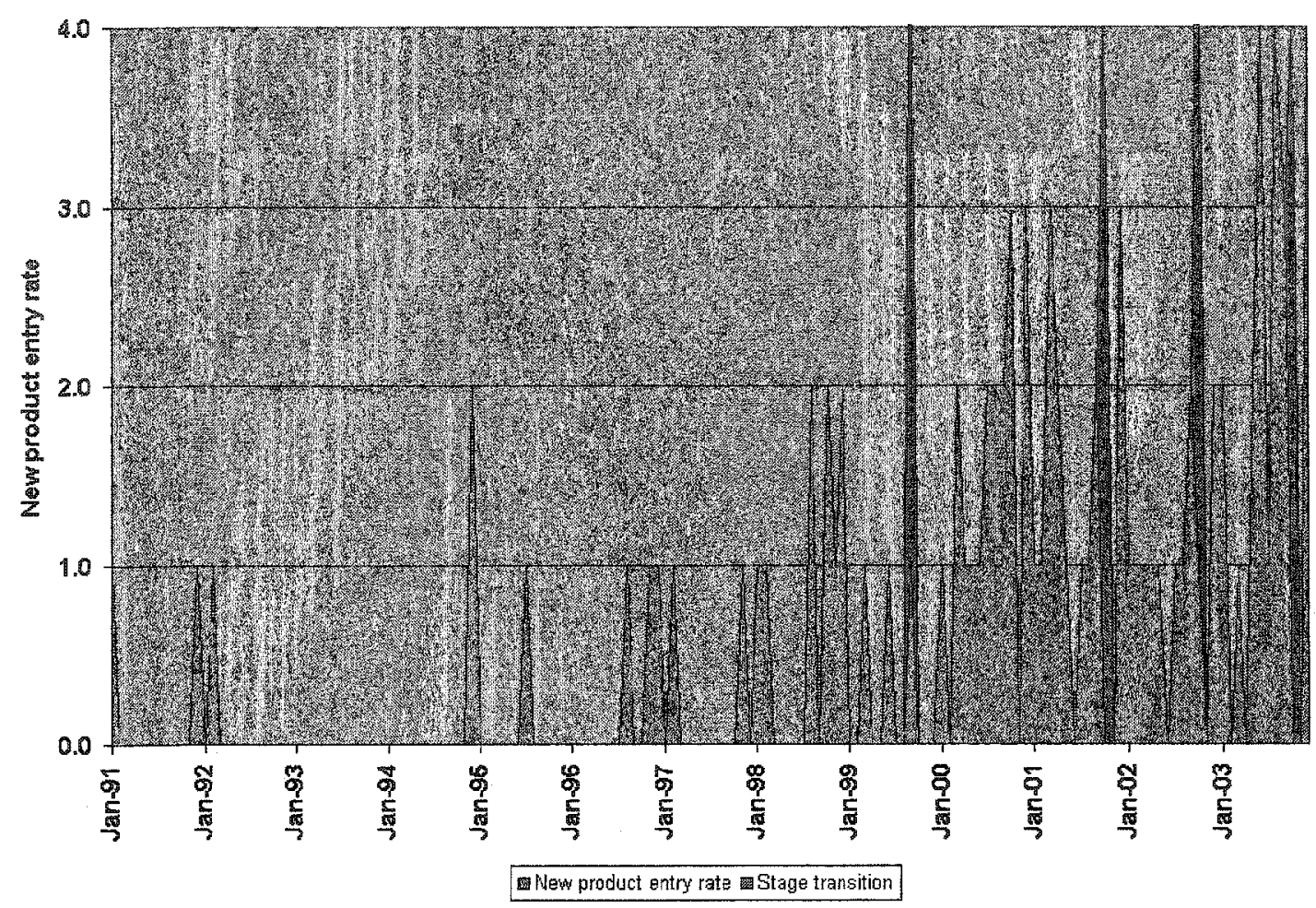

Figure 9 shows product density. Product density follows the same pattern as the supplier diversity. 
Tigure 9 New product density and stage tramsitions

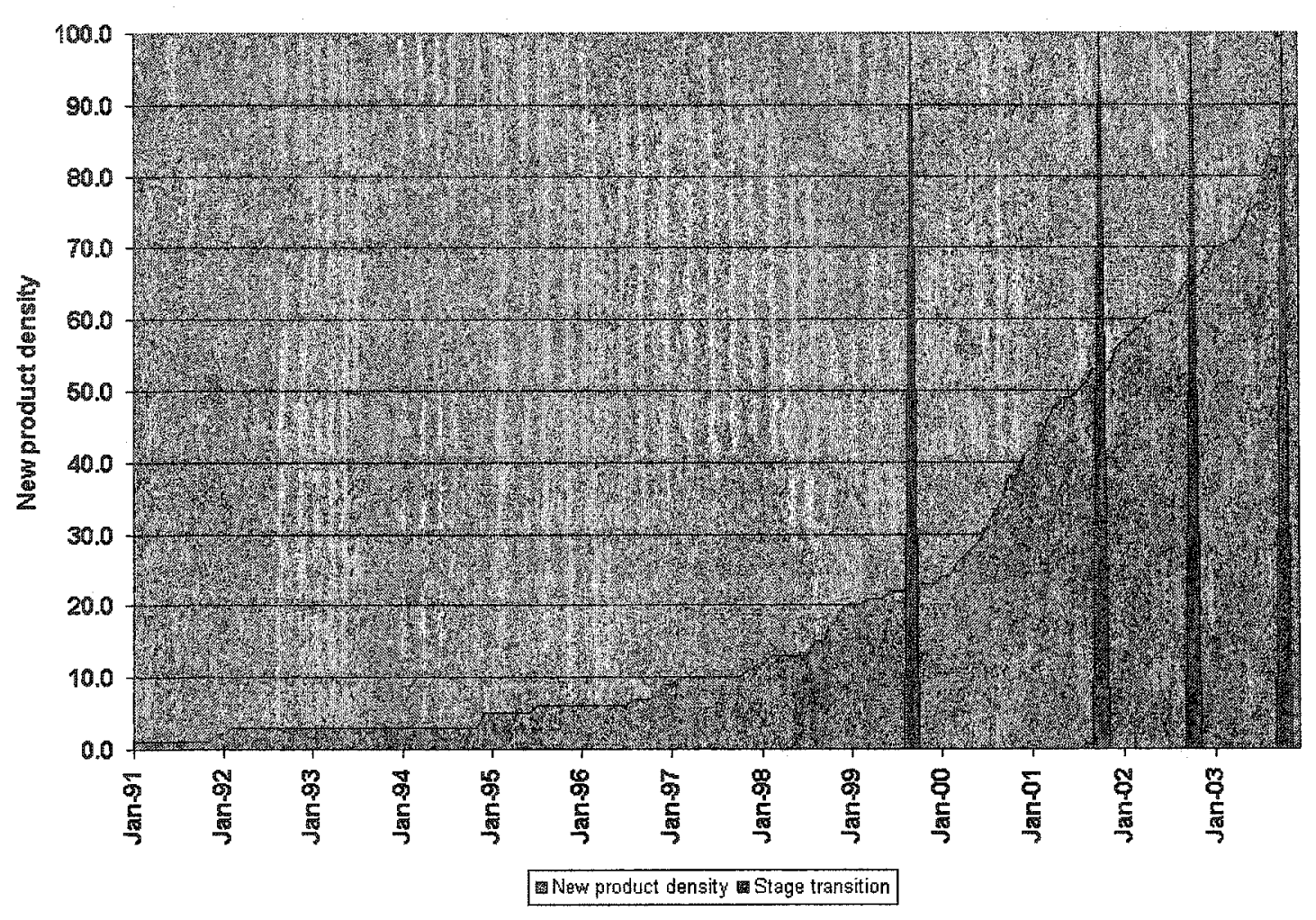

Product entry rate is scattered from January 1991 to January 1999; during 1999 the rate increases in a measured way, then from January 2000 to December 2003 it increases rapidly.

\subsubsection{Product types}

Table 18 provides the breakdown of the number of suppliers in the sample by product category. 
Table 18 Number of products by product category

\begin{tabular}{|l|r|r|}
\hline Product category & Number & Percentage \\
\hline Modeling only & 18 & $20.22 \%$ \\
\hline Reverse-engineering & 11 & $12.36 \%$ \\
\hline Forward-engineering & 27 & $30.34 \%$ \\
\hline Round-trip engineering & 23 & $25.84 \%$ \\
\hline Product suite & 10 & $11.24 \%$ \\
\hline Totals & 89 & $100.00 \%$ \\
\hline
\end{tabular}

Figure 10 illustrates product diversity over the study period. Diversity increases rapidly at the beginning of the study period and then levels off.

Table 19 shows the descriptive statistics for product categories. All product categories have a positive skewness coefficient indicating that their distributions are skewed to the right. 
Tigure 10 Produce diversity and stage transition

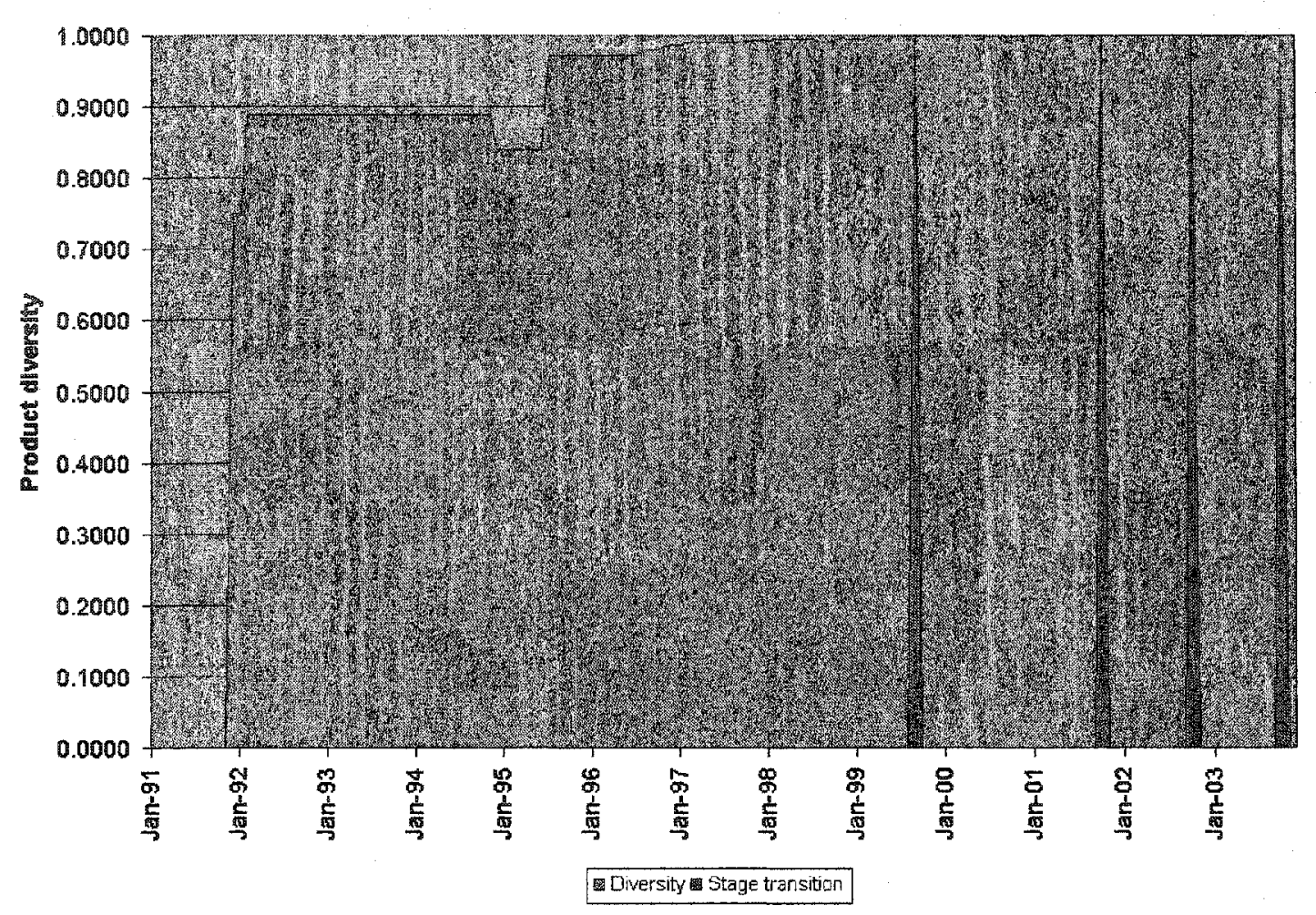

Table 19 Descriptive statistics for product categories

$$
(\mathrm{N}=156)
$$

\begin{tabular}{|l|c|c|c|c|c|c|c|c|c|}
\hline & Mean & Variance & $\begin{array}{l}\text { Standard } \\
\text { deviation }\end{array}$ & $\begin{array}{c}\text { Standard } \\
\text { error }\end{array}$ & $\begin{array}{c}\text { Coefficient- } \\
\text { of-variation }\end{array}$ & $\begin{array}{c}\text { Coeffici } \\
\text { ent }\end{array}$ & $p$ & $\begin{array}{c}\text { Coeffici } \\
\text { ent }\end{array}$ & $p$ \\
\hline $\begin{array}{l}\text { Modeling } \\
\text { only }\end{array}$ & 0.115 & 0.1027 & 0.3205 & 0.0257 & $278 \%$ & 2.4312 & $<0.0001$ & 3.9611 & $<0.0001$ \\
\hline $\begin{array}{l}\text { Reverse- } \\
\text { engineering }\end{array}$ & 0.071 & 0.0660 & 0.2568 & 0.0206 & $364 \%$ & 3.3879 & $<0.0001$ & 9.6009 & $<0.0001$ \\
\hline $\begin{array}{l}\text { Forward- } \\
\text { engineering }\end{array}$ & 0.173 & 0.2215 & 0.4706 & 0.0377 & $272 \%$ & 3.5347 & $<0.0001$ & 15.7646 & $<0.0001$ \\
\hline $\begin{array}{l}\text { Round-trip } \\
\text { engineering }\end{array}$ & 0.147 & 0.1394 & 0.3734 & 0.0299 & $253 \%$ & 2.3782 & $<0.0001$ & 4.8553 & $<0.0001$ \\
\hline $\begin{array}{l}\text { Product } \\
\text { suite }\end{array}$ & 0.064 & 0.0733 & 0.2707 & 0.0217 & $422 \% 4.5377$ & $<0.0001$ & 22.1470 & $<0.0001$ \\
\hline
\end{tabular}




\subsection{Testing hypothesis 2.}

The Mann-Whitney U test was used to test hypothesis 2: The type of new product is a function of the adoption stage.

Table 20 shows the results of using the Mann-Whitney $U$ test to compare the product types at stages 1 and 2 . The results indicate that the mean rank of the product types at stage 1 is larger than at stage 2 .

Table 20 Mann-Whitney $U$ test comparing product types between stages

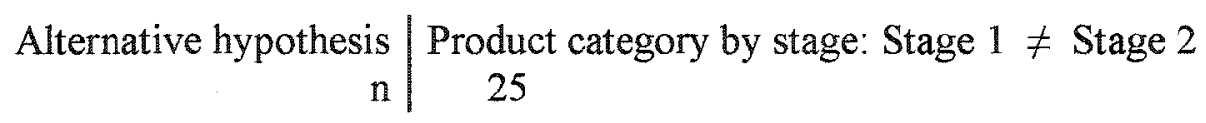

\begin{tabular}{r|c|c|c|c} 
Product category by stage & $\mathrm{n}$ & Rank sum & Mean rank & $\mathrm{U}$ \\
\hline Stage 1 & 6 & 81.5 & 13.58 & 53.5 \\
Stage 2 & 19 & 243.5 & 12.82 & 60.5
\end{tabular}

$\begin{array}{r}\text { Difference between } \\ \text { medians } \\ 95 \% \mathrm{CI}\end{array} \mid$

\begin{tabular}{r|cc} 
Mann-Whitney U statistic & 53.5 & \\
2 -tailed $\mathrm{p}$ & $0.8165 \quad$ (normal approximation, corrected for ties)
\end{tabular}

Appendix $V$ provides the Mann-Whitney $U$ tests for the remaining pairs of stages. 
The results of all Mann-Whitney $U$ tests show the following results:

- The mean rank of the product types at stage 1 is larger than that at stage 2

- The mean rank of the product types at stage 2 is larger than at stage 3

- The mean rank of the product types at stage 3 is significantly larger than at stage 4

The results provide support for hypothesis 2 . Results suggest that there is an association between the product category and the adoption stage.

\subsection{Testing hypothesis 3a}

The Mann-Whitney U test was used to test hypothesis 3a: Product diversity increases rapidly during the early stages, then increases slowly towards the later stages.

Table 21 provides the descriptive statistics for product diversity by adoption stage. For all stages, product diversity does not follow a normal distribution. For this reason the MannWhitney U test was used to compare product diversity in all 4 stages. Product diversity at stages 1,2 , and 3 has a negative skewness coefficient indicating that the distributions are skewed to the left. This means that product diversity increases during each stage. 
Table 21 Descriptive statistics for product diversity by stage

\begin{tabular}{|c|c|c|c|c|c|c|c|c|c|c|}
\hline \multirow{2}{*}{$\begin{array}{l}\text { Product } \\
\text { diversity } \\
\text { by stage } \\
\end{array}$} & \multirow[b]{2}{*}{ n } & \multirow[b]{2}{*}{ Mean } & \multirow[b]{2}{*}{ Variance } & \multirow[b]{2}{*}{$\begin{array}{l}\text { Standard } \\
\text { deviation }\end{array}$} & \multirow[b]{2}{*}{$\begin{array}{c}\text { Standard } \\
\text { error }\end{array}$} & \multirow[b]{2}{*}{$\begin{array}{l}\text { Coefficient- } \\
\text { of-variation }\end{array}$} & \multicolumn{2}{|c|}{ Skewness } & \multicolumn{2}{|c|}{ Kurtosis } \\
\hline & & & & & & & $\begin{array}{c}\text { Coeffici } \\
\text { ent }\end{array}$ & $p$ & $\begin{array}{c}\text { Coeffici } \\
\text { ent }\end{array}$ & $p$ \\
\hline Stage 1 & 129 & 0.867 & 0.0740 & 0.2720 & 0.0239 & $31 \%$ & -2.7759 & $<0.0001$ & 6.2702 & $<0.0001$ \\
\hline Stage 2 & 12 & 1.000 & 0.0000 & 0.0002 & 0.0001 & $0 \%$ & -1.4050 & 0,0313 & 0.7830 & $\ldots$ \\
\hline Stage 3 & 12 & 0.999 & 0.0000 & 0.0005 & 0.0001 & $0 \%$ & -1.9134 & .0052 & 2.4445 & $=$ \\
\hline Stage 4 & 3 & 0.999 & 0.0000 & 0.0002 & 0.0001 & $0 \%$ & . & - & $=$ & - \\
\hline
\end{tabular}

Table 22 shows the results from the Mann-Whitney U test that compared product diversity between stages 1 and 2 . Product diversity at stage 1 is significantly smaller than that at stage 2.

Appendix VI provides the Mann-Whitney $U$ tests for the remaining pairs of stages. The results of all Mann-Whitney $U$ tests provide the following results:

- Product diversity at stage 1 is significantly smaller than at stage 2 .

- Product diversity at stage 2 is significantly smaller than at stage 3 .

- Product diversity at stage 3 is significantly larger than at stage 4 .

The results support the acceptance of hypothesis 3 a suggesting that product diversity grows rapidly during the early stages then get saturated at the later stages. 
Table 22 Mann-Whitney $U$ test comparing product diversity between stages \begin{tabular}{r|r} 
Alternative hypothesis & Product diversity by stage: Stage $1 \neq$ Stage 2 \\
$\mathrm{n}$ & 141
\end{tabular}

\begin{tabular}{r|c|c|c|c} 
Product diversity by & & & \\
stage & $\mathrm{n}$ & Rank sum & Mean rank & $\mathrm{U}$ \\
\hline Stage 1 & 129 & 8410.0 & 65.19 & 1523.0 \\
Stage 2 & 12 & 1601.0 & 133.42 & 25.0
\end{tabular}

\begin{tabular}{r|rrr} 
Difference between & & & \\
medians & -0.02707 & & \\
$95.1 \% \mathrm{CI}$ & -0.11080 & to $-0.00666 \quad$ (normal approximation)
\end{tabular}

\begin{tabular}{r|cc} 
Mann-Whitney U statistic & 1523 \\
2-tailed $p$ & $<0.0001 \quad$ (normal approximation, corrected for ties)
\end{tabular}

\subsection{Testing hypothesis $\mathbf{3 b}$}

The Man-Whitney U test was used to test hypothesis $3 \mathrm{~b}$ : Supplier diversity increases rapidly during the early stages, then increases slowly towards the later stages.

Table 23 provides the descriptive statistics for supplier diversity by adoption stage. For stages 1,2 , and 3 , supplier diversity does not follow a normal distribution. For this reason, the Mann-Whitney U test was used to compare supplier diversity. Supplier diversity at stage 1 has a negative skewness coefficient indicating that the distribution is skewed to the left. Supplier diversity at stages 2 and 3 have a positive skewness coefficient indicating that the distributions are skewed to the right. This means that during stage 1 supplier diversity increases at the beginning of the stage then decreases towards the end of the stage. This is 
due to suppliers exiting the UML-based development tools market. During stages 2 and 3 supplier diversity increases, meaning that the number of suppliers entering the UML-based development tools market is growing. During stage 4 supplier diversity has a normal distribution, meaning that at the beginning of the stage the number of suppliers entering the UML-based development tools market is growing then some suppliers exit the market.

Table 23 Descriptive statistics for supplier diversity by stage

\begin{tabular}{|c|c|c|c|c|c|c|c|c|c|c|}
\hline $\begin{array}{c}\text { Supplier } \\
\text { diversity } \\
\text { by stage }\end{array}$ & $\mathrm{n}$ & Mean & Variance & $\begin{array}{c}\text { Standard } \\
\text { deviation }\end{array}$ & $\begin{array}{c}\text { Standard } \\
\text { error }\end{array}$ & $\begin{array}{c}\text { Coefficient- } \\
\text { of-variation }\end{array}$ & $\begin{array}{c}\text { Coeffici } \\
\text { ent }\end{array}$ & $p$ & $\begin{array}{c}\text { Coeffici } \\
\text { ent }\end{array}$ & $p$ \\
\hline Stage 1 & 129 & $\begin{array}{c}0.856 \\
96\end{array}$ & 0.071729 & 0.267823 & 0.023580 & $31 \%$ & -2.8045 & $<0.0001$ & 6.3976 & $<0.0001$ \\
\hline Stage 2 & 12 & $\begin{array}{c}0.999 \\
01\end{array}$ & 0.000000 & 0.99901 & 0.000195 & $0 \%$ & -0.4141 & 0.4987 & -1.4844 & - \\
\hline Stage 3 & 12 & $\begin{array}{c}0.999 \\
04\end{array}$ & 0.000001 & 0.99904 & 0.000231 & $0 \%$ & -1.2426 & 0.0535 & 0.7196 & - \\
\hline Stage 4 & 3 & $\begin{array}{c}0.999 \\
01\end{array}$ & 0.000000 & 0.99901 & 0.000088 & $0 \%$ & - & & & - \\
\hline
\end{tabular}

Table 24 shows the results from the Mann-Whitney $U$ test comparing supplier diversity for stage 1 and stage 2. Supplier diversity at stage 1 is significantly smaller than at stage 2 . 
Table 24 Mann-Whitney $\mathbf{U}$ test comparing supplier diversity between stages

\begin{tabular}{r|c} 
Alternative hypothesis & Supplier diversity by stage: Stage $1 \neq$ Stage 2 \\
$\mathrm{n}$ & 141
\end{tabular}

\begin{tabular}{r|r|r|r|r} 
Supplier diversity by & & & \\
stage & $\mathrm{n}$ & Rank sum & Mean rank & \multicolumn{1}{c}{$\mathrm{U}$} \\
\hline Stage 1 & 129 & 8439.5 & 65.42 & 1493.5 \\
Stage 2 & 12 & 1571.5 & 130.96 & 54.5
\end{tabular}

\begin{tabular}{r|rr} 
Difference between & & \\
medians & -0.10903 & \\
$95.1 \% \mathrm{CI}$ & -0.10974 to $-0.01524 \quad$ (normal approximation)
\end{tabular}

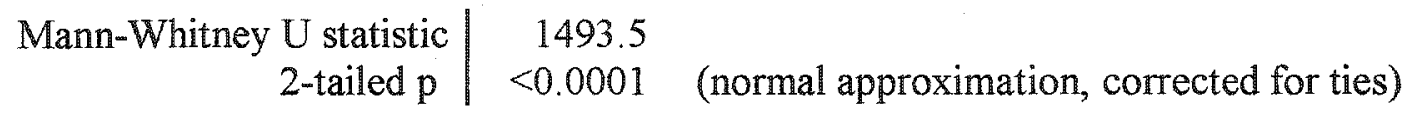

Appendix VII provides the Mann-Whitney $U$ tests for the remaining pairs of stages. The results of all Mann-Whitney $U$ tests show the following results:

- Product diversity at stage 1 is significantly smaller than at stage 2

- Product diversity at stage 2 is significantly smaller than at stage 3

- Product diversity at stage 3 is larger than at stage 4

Table 25 shows the results of 1-way ANOVA for supplier diversity by stage. Product diversity at stage 1 is lower than at the other three stages; the mean difference between product diversity at stages 1 and 2 is significantly greater than the mean difference between product diversity at stages 2 and 3 . 
Table 251 -way between subjects ANOVA Supplier diversity by stage

\begin{tabular}{|c|r|c|c|c|}
\hline $\begin{array}{c}\text { Supplier } \\
\text { diversity } \\
\text { by stage }\end{array}$ & \multicolumn{1}{c|}{$\mathrm{n}$} & Mean & $\begin{array}{c}\text { Standard } \\
\text { deviation }\end{array}$ & $\begin{array}{c}\text { Standard } \\
\text { error }\end{array}$ \\
\hline Stage 1 & 129 & 0.85696 & 0.26782 & 0.023580 \\
\hline Stage 2 & 12 & 0.99901 & 0.00067 & 0.000195 \\
\hline Stage 3 & 12 & 0.99904 & 0.00080 & 0.000231 \\
\hline Stage 4 & 3 & 0.99901 & 0.00015 & 0.000088 \\
\hline
\end{tabular}

\begin{tabular}{|c|c|c|c|c|c|}
\hline $\begin{array}{c}\text { Source of } \\
\text { variation }\end{array}$ & $\begin{array}{c}\text { Sum of } \\
\text { squares }\end{array}$ & $\begin{array}{c}\text { Degrees of } \\
\text { freedom }\end{array}$ & $\begin{array}{c}\text { Mean } \\
\text { square }\end{array}$ & $\begin{array}{c}\text { Ratio of Mean } \\
\text { square / Mean } \\
\text { square within }\end{array}$ & $\begin{array}{c}p \\
\text { (probability) }\end{array}$ \\
\hline Stage & 0.45061 & 3 & 0.15020 & 2.49 & 0.0627 \\
\hline $\begin{array}{c}\text { Within } \\
\text { cells }\end{array}$ & 9.18134 & 152 & 0.06040 & 0.06040 & \\
\hline Total & 9.63195 & 155 & & & \\
\hline
\end{tabular}

The results support the acceptance of hypothesis $3 \mathrm{~b}$ suggesting that supplier diversity grows rapidly during the early stages then it levels off at the later stages.

\subsection{Testing hypothesis $3 \mathrm{c}$}

Hypothesis $3 \mathrm{c}$ : Buyer diversity increases rapidly during the early stages.

Figure 11 shows the buyer diversity by vertical market. Diversity changes over the study period, increasing rapidly at the beginning of 2000 then leveling off at the end of the study period. Diversity in Figure 11 is based on buyer type. Twenty four types of buyers were identified based on their vertical market. 
Figure 11 Buyer diversity by vertical market

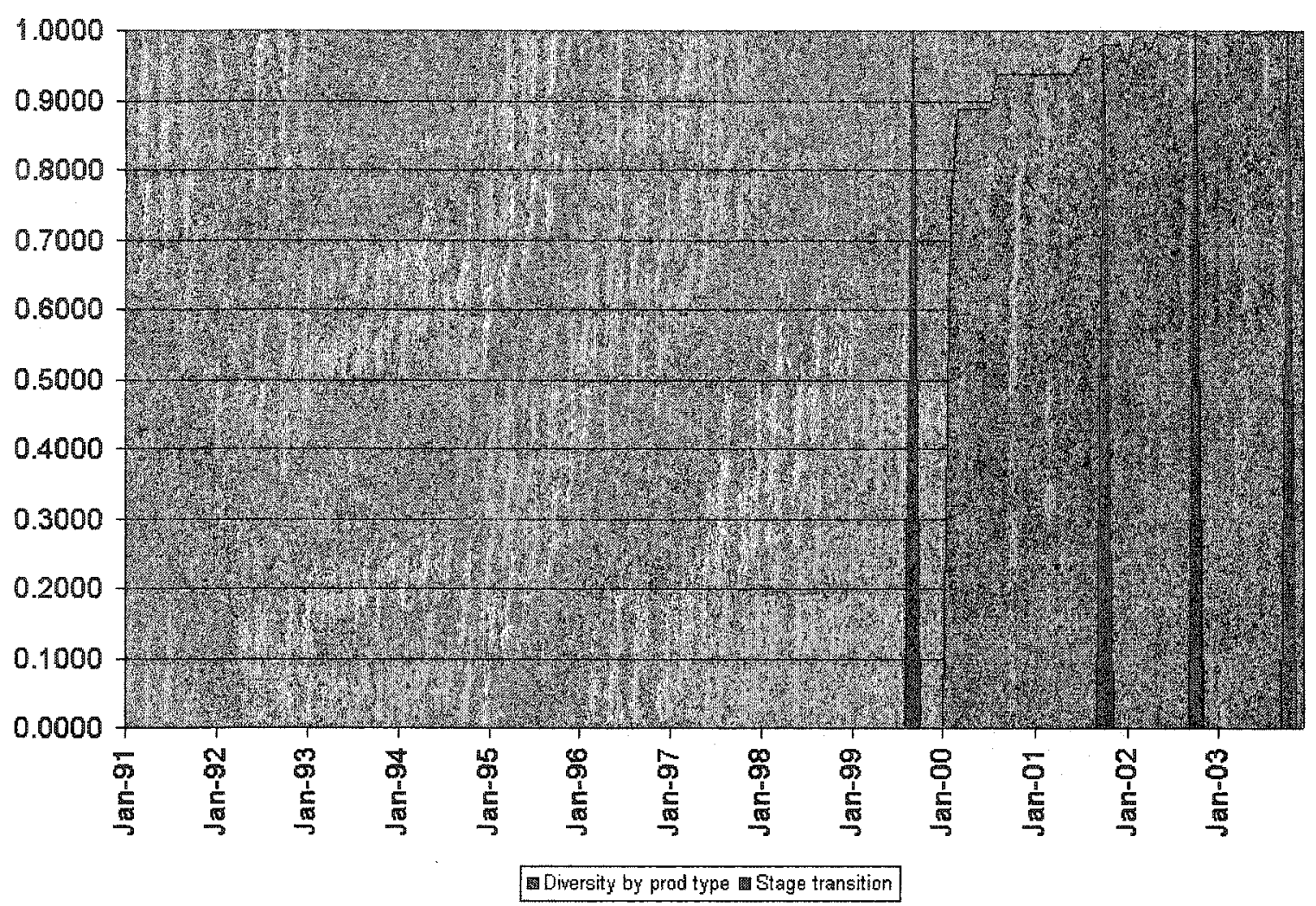

Table 26 provides the descriptive statistics for buyer diversity by adoption stage. For all stages, buyer diversity does not follow a normal distribution. For this reason, the MannWhitney $U$ test was used to compare buyer diversity in all four stages. Buyer diversity at stage 1 has a positive skewness coefficient indicating that the distribution is skewed to the right. Buyer diversity at stages 2 and 3 has a negative skewness coefficient indicating that the distributions are skewed to the left. This means that buyer diversity grew at the beginning of stage 1 then decreased by the end of the stage. During stages 2 and 3 buyer diversity kept growing. During stage 4 buyer diversity grew at the beginning of the stage then started to decrease towards the end of the stage. 
Table 26 Descriptive statistics for buyer diversity by stage

\begin{tabular}{|l|c|c|c|c|c|c|c|c|c|c|}
\hline $\begin{array}{l}\text { Buyer } \\
\text { diversity } \\
\text { by stage }\end{array}$ & $\mathrm{N}$ & Mean & Variance & $\begin{array}{c}\text { Standard } \\
\text { deviation }\end{array}$ & $\begin{array}{c}\text { Standard } \\
\text { error }\end{array}$ & $\begin{array}{c}\text { Coefficient- } \\
\text { of-variation }\end{array}$ & $\begin{array}{c}\text { Coeffici } \\
\text { ent }\end{array}$ & $p$ & $\begin{array}{c}\text { Coeffici } \\
\text { ent }\end{array}$ & $p$ \\
\hline Stage 1 & 129 & 0.14263 & 0.112072 & 0.334772 & 0.029475 & $235 \%$ & 1.9402 & $<0.0001$ & 1.8104 & 0.0051 \\
\hline Stage 2 & 12 & 0.98606 & 0.000052 & 0.007184 & 0.002074 & $1 \%$ & -0.0245 & 0.9678 & -1.7696 & - \\
\hline Stage 3 & 12 & 0.99746 & 0.000003 & 0.001623 & 0.000469 & $0 \%$ & -0.4632 & 0.4500 & -0.6583 & - \\
\hline Stage 4 & 3 & 0.99901 & 0.000000 & 0.000282 & 0.000163 & $0 \%$ & - & - & - & - \\
\hline
\end{tabular}

Table 27 shows the results from the Mann-Whitney $U$ test comparing buyer diversity between stage 1 and stage 2 . Buyer diversity at stage 1 is significantly smaller than that at stage 2 .

Appendix VIII provides the Mann-Whitney $U$ tests for the remaining pairs of stages. The results of all Mann-Whitney $U$ tests provide the following results:

- Buyer diversity at stage 1 is significantly smaller than at stage 2 .

- Buyer diversity at stage 2 is significantly smaller than at stage 3 .

- Buyer diversity at stage 3 is smaller than at stage 4 .

The results support the acceptance of hypothesis $3 c$, suggesting that buyer diversity grows rapidly during the early stages then levels off at the later stages. 
Table 27 Mann-Whitney $U$ test comparing buy er diversity between stages \begin{tabular}{r|r} 
Alternative hypothesis & Buyer diversity by stage: Stage $1 \neq$ Stage 2 \\
$\mathbf{n}$ & 141
\end{tabular}

\begin{tabular}{|c|c|c|c|c|}
\hline $\begin{array}{r}\text { Supplier diversity by } \\
\text { stage }\end{array}$ & $\mathrm{n}$ & Rank sum & Mean rank & U \\
\hline Stage 1 & 129 & 8385.0 & 65.00 & 1548.0 \\
\hline Stage 2 & 12 & 1626.0 & 135.50 & 0.0 \\
\hline
\end{tabular}

\begin{tabular}{r|rrr} 
Difference between & & & \\
medians & -0.98047 & & \\
$95.1 \% \mathrm{CI}$ & -0.99174 & to $-0.97959 \quad$ (normal approximation)
\end{tabular}

\begin{tabular}{r|r} 
Mann-Whitney U statistic & 1548 \\
2 -tailed $p$ & $<0.0001 \quad$ (normal approximation, corrected for ties)
\end{tabular}

\subsection{Testing hypothesis $4 a$}

Hypothesis 4a: New buyers' entry rate follows a bell shape distribution.

Table 28 provides the descriptive statistics for buyer entry rate by adoption stage. For stages 1,2 , and 3 the buyer entry rate is not normally distributed. For this reason the MannWhitney $U$ test was used to compare supplier diversity. Supplier diversity at stages 1,2 , and 3 has a positive skewness coefficient indicating that the distributions are skewed to the right. This means that the buyer entry keeps growing from stage 1 to stage 3 . During stage 4 the buyer entry rate keeps growing at the beginning of the stage then starts decreasing. 
Table 28 Descriptive statistics for buyers" entry rate by adoption stage

\begin{tabular}{|c|c|c|c|c|c|c|c|c|c|c|}
\hline \multirow{2}{*}{$\begin{array}{l}\text { Buyer } \\
\text { entry rate } \\
\text { by stage }\end{array}$} & \multirow[b]{2}{*}{$\mathrm{n}$} & \multirow[b]{2}{*}{ Mean } & \multirow[b]{2}{*}{ Variance } & \multirow[b]{2}{*}{$\begin{array}{r}\text { Standard } \\
\text { deviation }\end{array}$} & \multirow[b]{2}{*}{$\begin{array}{c}\begin{array}{c}\text { Standard } \\
\text { error }\end{array} \\
\end{array}$} & \multirow[b]{2}{*}{$\begin{array}{l}\text { Coefficient- } \\
\text { of-variation }\end{array}$} & \multicolumn{2}{|c|}{ Skewness } & \multicolumn{2}{|c|}{ Kurtosis } \\
\hline & & & & & & & $\begin{array}{c}\text { Coeffici } \\
\text { ent }\end{array}$ & $p$ & $\begin{array}{c}\text { Coeffici } \\
\text { ent }\end{array}$ & $p$ \\
\hline Stage 1 & 129 & 0.0 & 0.04 & 0.21 & 0.02 & $455 \%$ & 4.3577 & $<0.0001$ & 17.2566 & $<0.0001$ \\
\hline Stage 2 & 12 & 1.6 & 2.99 & 1.73 & 0.50 & $109 \%$ & 1.4123 & 0.0306 & 1.1057 & - \\
\hline Stage 3 & 12 & 2.3 & 4.42 & 2.10 & 0.61 & $90 \%$ & 0.8076 & 0.1954 & 0.6806 & - \\
\hline Stage 4 & 3 & 2.0 & 4.00 & 2.00 & 1.15 & $100 \%$ & - & - & - & - \\
\hline
\end{tabular}

Table 29 shows the results from the Mann-Whitney U test comparing the buyer entry rate for stage 1 and stage 2.

Appendix IX provides the Mann-Whitney $U$ tests for the remaining pairs of stages.

Table 29 Descriptive statistics for buyers' entry rate by adoption stage

Alternative hypothesis Supplier entry rate by stage: Stage $1 \neq$ Stage 2 n 141

\begin{tabular}{r|r|r|r|r} 
Supplier diversity by & & & \\
stage & $\mathrm{n}$ & Rank sum & Mean rank & \multicolumn{1}{c}{$\mathrm{U}$} \\
\hline Stage 1 & 129 & 8602.5 & 66.69 & 1330.5 \\
Stage 2 & 12 & 1408.5 & 117.38 & 217.5
\end{tabular}

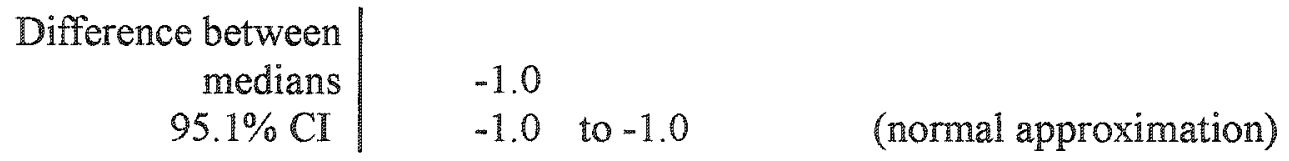

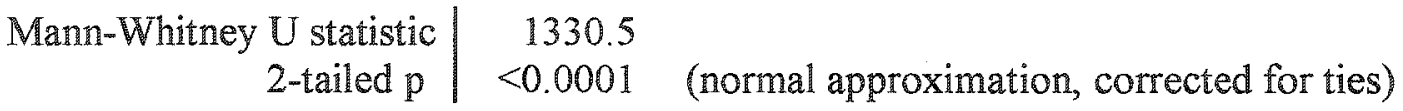


The results of all tests throw the following results:

- Buyer entry rate at stage 1 is significantly smaller than at stage 2

- Buyer entry rate at stage 2 is smaller than at stage 3

- Buyer entry rate at stage 3 is larger than at stage 4

The results support the acceptance of hypothesis $4 a$, suggesting that new buyers' entry rate follows a bell shaped distribution.

\subsection{Testing hypothesis $4 \mathrm{~b}$}

Hypothesis 4b: New suppliers' entry rate follows a bell shaped distribution.

Table 30 provides the descriptive statistics for buyer entry rate by adoption stage. For all stages, supplier diversity does not follow a normal distribution. For this reason, the MannWhitney $U$ test was used to compare supplier diversity in all 4 stages. Supplier entry rate at stages 1,2 , and 3 have a positive skewness coefficient indicating that the distributions are skewed to the right. This means that the supplier entry keeps growing from stage 1 to stage 3 . During stage 4, the supplier's entry rate grew at the beginning of the stage then starts to decrease towards the end of the stage. 
Table 30 Descriptive statistics for suppliers" entry rate by adoption stage

\begin{tabular}{|c|c|c|c|c|c|c|c|c|c|c|}
\hline $\begin{array}{c}\text { Supplier } \\
\text { entry rate } \\
\text { by stage }\end{array}$ & $\mathrm{N}$ & Mean & Variance & $\begin{array}{c}\text { Standard } \\
\text { deviation }\end{array}$ & $\begin{array}{c}\text { Standard } \\
\text { error }\end{array}$ & $\begin{array}{c}\text { Coefficient- } \\
\text { of-variation }\end{array}$ & $\begin{array}{c}\text { Coeffici } \\
\text { ent }\end{array}$ & $p$ & $\begin{array}{c}\text { Coeffici } \\
\text { ent }\end{array}$ & $p$ \\
\hline Stage 1 & 129 & 0.3 & 0.45 & 0.67 & 0.06 & & & & & \\
\hline Stage 2 & 12 & 0.9 & 0.81 & 0.90 & 0.26 & $98 \%$ & 2.0017 & $<0.0001$ & 3.6211 & $<0.0001$ \\
\hline Stage 3 & 12 & 1.0 & 1.45 & 1.21 & 0.35 & $121 \%$ & 0.7462 & 0.2299 & -1.0542 & - \\
\hline Stage 4 & 3 & 0.7 & 1.33 & 1.15 & 0.67 & $173 \%$ & - & - & - & - \\
\hline
\end{tabular}

Table 31 shows the results from the Mann-Whitney $U$ test comparing the buyer entry rate for stage 1 and stage 2 .

Table 31 Mann-Whitney U test comparing suppliers' entry rate between stages \begin{tabular}{r|c} 
Alternative hypothesis & Supplier entry rate by stage: Stage $1 \neq$ Stage 2 \\
$n$ & 141
\end{tabular}

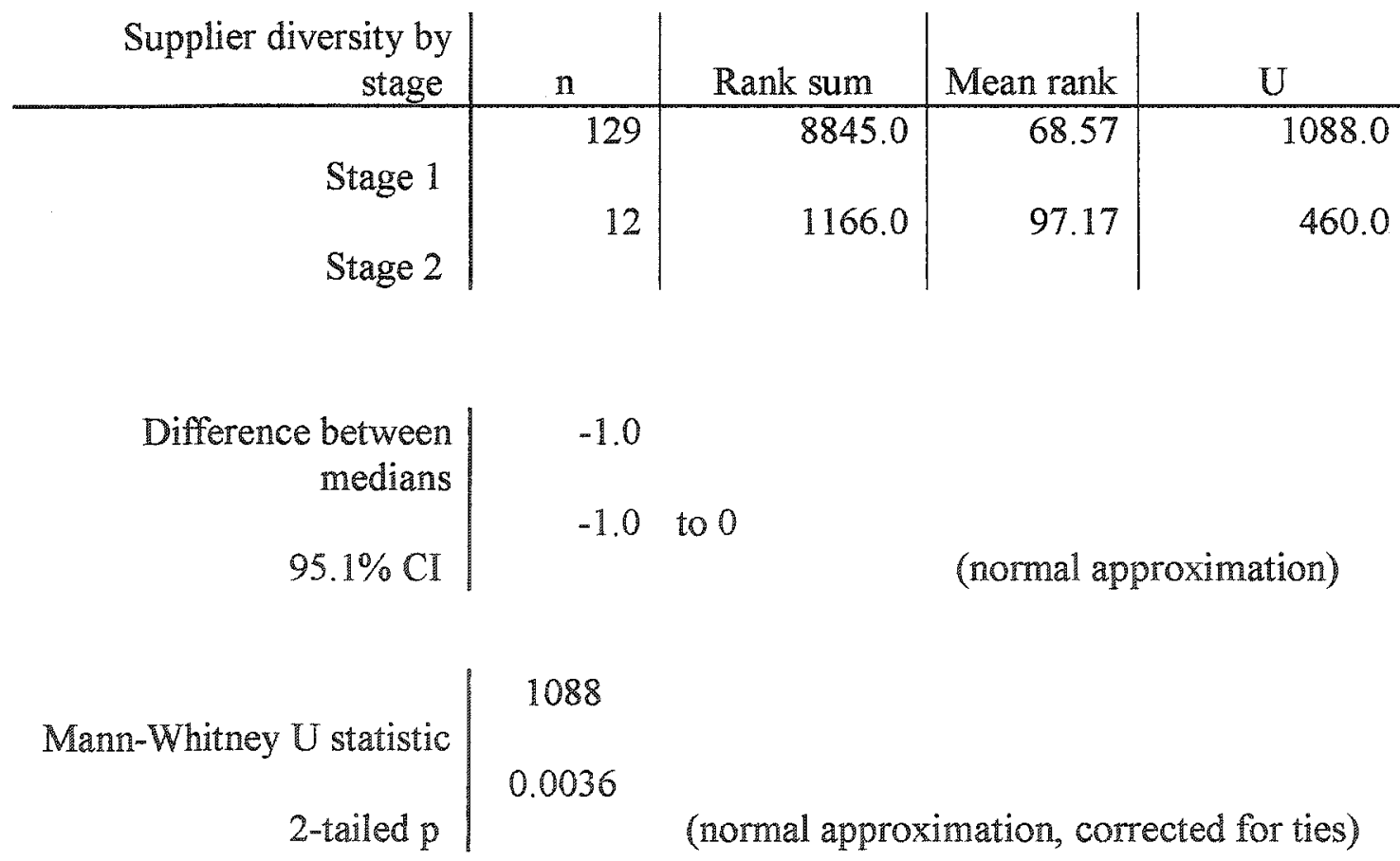


Appendix $\mathrm{X}$ provides the Mann-Whitney $\mathrm{U}$ tests for the remaining pairs of stages. The results of all tests throw the following results:

- Supplier entry rate at stage 1 is significantly smaller than at stage 2

- Supplier entry rate at stage 2 is slightly larger than at stage 3

- Supplier entry rate at stage 3 is larger than at stage 4

The results do not support the acceptance of hypothesis $4 b$, suggesting that new suppliers' entry rates do not follow a bell shaped distribution.

\subsection{Buyers' vertical markets}

Table 32 provides a breakdown of the number of buyers in the sample by vertical market.

The researcher used IDC's segmentation of software markets to classify buyers' type. Table 33 shows the descriptive statistics for buyers' vertical market.

Application design and construction tools and other services account for $20.34 \%$ each. Some developers of UML-based development tools are collaborating to supplement their applications with other products. Insurance, process manufacturing, wholesale, retail, business and legal, and mining had a zero percent rate. 
Table 32 Number of buyers by category based on vertical market

\begin{tabular}{|l|c|r|}
\hline \multicolumn{1}{|c|}{ Buyer category } & Number & Percentage \\
\hline Banking & 1 & $1.69 \%$ \\
\hline Financial services & 2 & $3.39 \%$ \\
\hline Insurance & 0 & $0.00 \%$ \\
\hline Discrete manufacturing & 2 & $3.39 \%$ \\
\hline Process manufacturing & 0 & $0.00 \%$ \\
\hline Automotive manufacturing & 5 & $8.47 \%$ \\
\hline Transportation & 3 & $5.08 \%$ \\
\hline Broadcast and other communications & 1 & $1.69 \%$ \\
\hline Utilities & 1 & $1.69 \%$ \\
\hline Wholesale & 0 & $0.00 \%$ \\
\hline Retail & 0 & $0.00 \%$ \\
\hline Healtcare & 0 & $0.00 \%$ \\
\hline Business and legal & 0 & $0.00 \%$ \\
\hline Engineering / management & 4 & $6.78 \%$ \\
\hline Other services & 12 & $20.34 \%$ \\
\hline Mining & 0 & $0.00 \%$ \\
\hline Agriculture / construction & 1 & $1.69 \%$ \\
\hline Government & 4 & $6.78 \%$ \\
\hline Education & 2 & $3.39 \%$ \\
\hline Telecommunications & 4 & $6.78 \%$ \\
\hline Information access and delivery & 2 & $3.39 \%$ \\
\hline Information and data management & 2 & $3.39 \%$ \\
\hline Application design and construction tools & 12 & $20.34 \%$ \\
\hline Application life cycle-management & 1 & $1.69 \%$ \\
\hline & 59 & $100.00 \%$ \\
\hline
\end{tabular}


Table 33 Descriptive statistics for buyers' vertical market

\begin{tabular}{|l|l|l|l|l|l|r|}
\hline & $\mathrm{N}$ & Mean & Variance SD & SE & $\mathrm{CV}$ \\
\hline Banking & 156 & 0.006 & 0.0064 & 0.0801 & 0.0064 & $1249 \%$ \\
\hline Financial services & 156 & 0.013 & 0.0127 & 0.1129 & 0.0090 & $880 \%$ \\
\hline Insurance & 156 & 0.000 & & - & - & \\
\hline Discrete manufacturing & 156 & 0.013 & 0.0127 & 0.1129 & 0.0090 & $880 \%$ \\
\hline Process manufacturing & 156 & 0.000 & & - & - & \\
\hline Automotive manufacturing & 156 & 0.032 & 0.0312 & 0.1767 & 0.0141 & $551 \%$ \\
\hline Transportation & 156 & 0.019 & 0.0190 & 0.1378 & 0.0110 & $716 \%$ \\
\hline Broadcast and other communications & 156 & 0.006 & 0.0064 & 0.0801 & 0.0064 & $1249 \%$ \\
\hline Utilities & 156 & 0.006 & 0.0064 & 0.0801 & 0.0064 & $1249 \%$ \\
\hline Wholesale & 156 & 0.000 & & - & - & \\
\hline Retail & 156 & 0.000 & & - & - & \\
\hline Healthcare & 156 & 0.000 & & - & - & \\
\hline Business and legal & 156 & 0.000 & & - & - & \\
\hline Engineering / management & 156 & 0.026 & 0.0251 & 0.1586 & 0.0127 & $618 \%$ \\
\hline Other services & 156 & 0.077 & 0.0973 & 0.3119 & 0.0250 & $405 \%$ \\
\hline Mining & 156 & 0.000 & & - & - & \\
\hline Agriculture / construction & 156 & 0.006 & 0.0064 & 0.0801 & 0.0064 & $1249 \%$ \\
\hline Government & 156 & 0.026 & 0.0251 & 0.1586 & 0.0127 & $618 \%$ \\
\hline Education & 156 & 0.013 & 0.0127 & 0.1129 & 0.0090 & $880 \%$ \\
\hline Telecommunications & 156 & 0.026 & 0.0251 & 0.1586 & 0.0127 & $618 \%$ \\
\hline Information access and delivery & 156 & 0.013 & 0.0127 & 0.1129 & 0.0090 & $880 \%$ \\
\hline Information and data management & 156 & 0.013 & 0.0127 & 0.1129 & 0.0090 & $880 \%$ \\
\hline Application design and construction tools & 156 & 0.077 & 0.1231 & 0.3508 & 0.0281 & $456 \%$ \\
\hline Application life cycle-management & 156 & 0.006 & 0.0064 & 0.0801 & 0.0064 & $1249 \%$ \\
\hline
\end{tabular}

\subsection{Suppliers' reasons for commitment}

Suppliers' reasons for commitment were obtained from quotes found in suppliers' news releases and announcements. The quotes for all news releases and announcements were analyzed and a total of seven different reasons for suppliers to commit were identified. Table 34 shows the keywords used to identify suppliers' reasons to commit to UML-based development tools. 
Table 34 Suppliers reasons to commit keywords

\begin{tabular}{|l|l|}
\hline \multicolumn{1}{|c|}{ Suppliers reasons to commi } & \multicolumn{1}{c|}{ Keywords } \\
\hline Add new features & Provide new, now include, offers \\
\hline Capture niche market & Market niche, targeted to \\
\hline Commit to open standards & Commit, open standard \\
\hline Enter the market & First release \\
\hline $\begin{array}{l}\text { Offer reduced cycle time } \\
\text { Participation in standards } \\
\text { definition }\end{array}$ & $\begin{array}{l}\text { Save time, reduce cycle, increase } \\
\text { productivity }\end{array}$ \\
\hline Supplement application & Participate, define, standard \\
\hline
\end{tabular}

Table 35 and figure 12 show the frequency distribution for suppliers' reasons to commit to UML-based development tools.

Table 35 Frequency distribution for suppliers' reasons to commit

\begin{tabular}{|l|c|c|}
\hline \multicolumn{1}{|c|}{ Suppliers' reasons to commit } & Number & Percentage \\
\hline Add new features & 32 & $29.36 \%$ \\
\hline Capture niche market & 10 & $9.17 \%$ \\
\hline Commit to open standards & 10 & $9.17 \%$ \\
\hline Enter the market & 22 & $20.18 \%$ \\
\hline Offer reduced cycle time & 10 & $9.17 \%$ \\
\hline Participation in standards definitions & 6 & $5.50 \%$ \\
\hline Supplement application & 19 & $17.43 \%$ \\
\hline & 109 & $100.00 \%$ \\
\hline
\end{tabular}

Table 36 shows the suppliers' reasons to commit to UML-based development tools categorical summary descriptive statistics. 
Table 36 Sumpliers' reasons for commitment categorical summary descriptive statistics

\begin{tabular}{r|l} 
Variable & Suppliers' reason to commit \\
n & 109 \\
Groups & 7 \\
Mode & Add new features
\end{tabular}

Figure 12 Suppliers' reasons for commitment

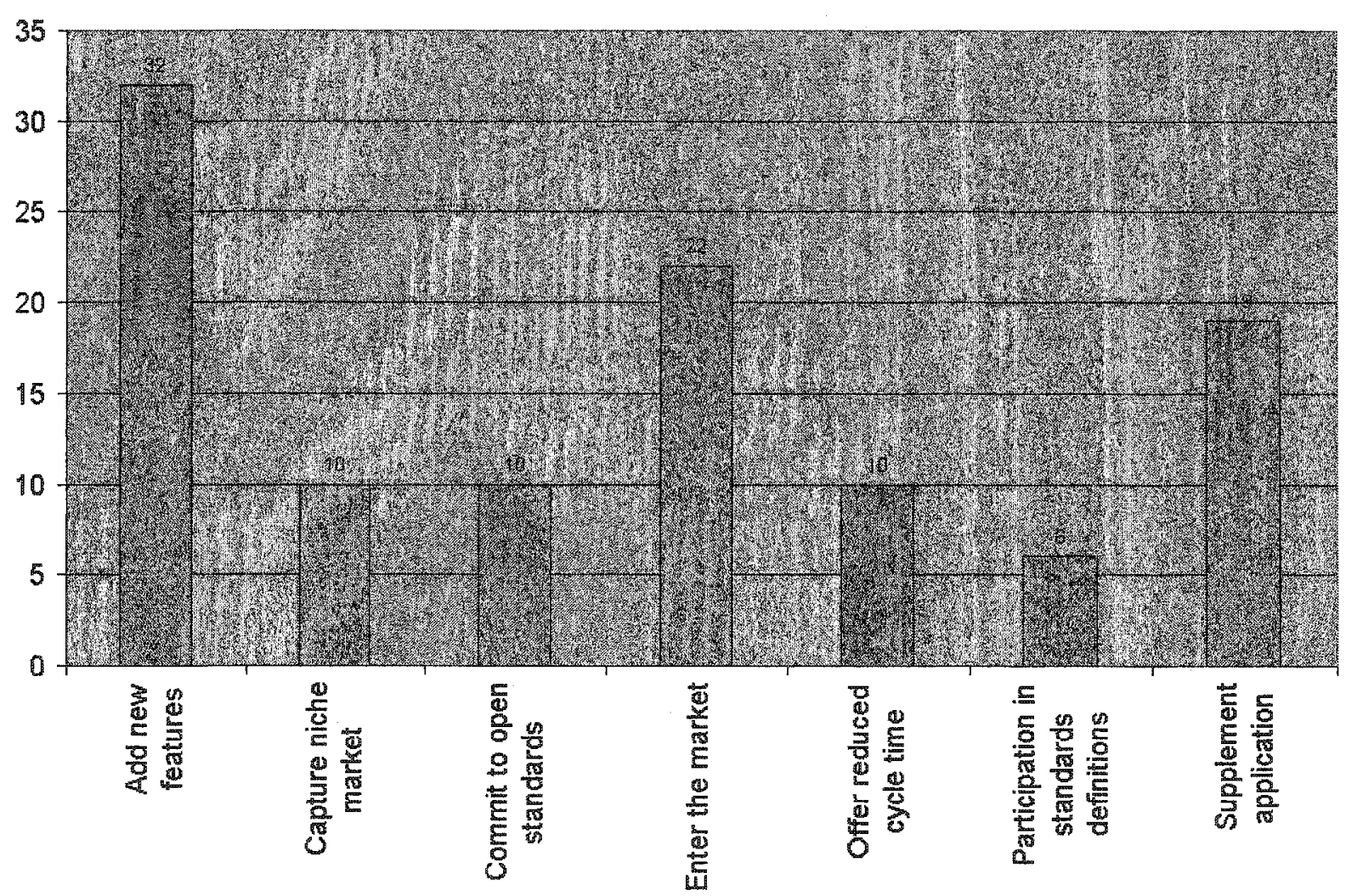




\subsection{Testing hypothesis 5 a}

Hypothesis 5a: Reasons for which suppliers commit to UML-based development tools are a function of the adoption stage. Test the association between the suppliers' reasons to commit to UML-based development tools and the adoption stage.

Table 37 shows the results of using the Mann-Whitney $U$ test comparing the suppliers' reasons to commit at stages 1 and 2 . The results indicate that the mean rank of the supplier size at stage 1 is significantly larger than at stage 2 .

Appendix XI provides the Mann-Whitney U tests for the remaining pairs of stages. The results of all Mann-Whitney $U$ tests throw the following results:

- The mean rank of suppliers' reasons to commit to UML-based development tools at stage 1 are significantly smaller than the mean rank at stage 2

- The mean rank of suppliers' reasons to commit to UML-based development tools at stage 2 is slightly smaller than the mean rank at stage 3

- The mean rank of suppliers' reasons to commit to UML-based development tools at stage 2 is significantly larger than the mean rank at stage 3 
The results support the acceptance of hypothesis $\mathrm{H} 5 \mathrm{a}$, suggesting that there is an association between the suppliers' reasons to commit and the adoption stage. However, this association weakens as the adoption process advances. 
Table 37 Mann-Whitney U test comparing suppliers" reasons to commin between stages

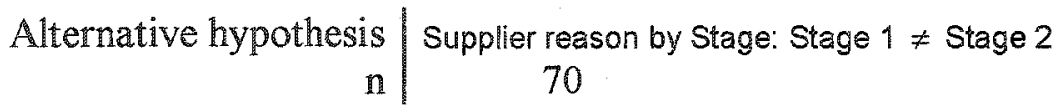

\begin{tabular}{r|r|r|r|r}
$\begin{array}{r}\text { Supplier diversity by } \\
\text { stage }\end{array}$ & $\mathrm{n}$ & Rank sum & Mean rank & $\mathrm{U}$ \\
\hline Stage 1 & 38 & 1304.5 & 34.33 & 652.5 \\
Stage 2 & 32 & 1180.5 & 36.89 & 563.5
\end{tabular}

Difference between medians $95.1 \% \mathrm{CI}$

Mann-Whitney U statistic 2-tailed $\mathrm{p}$
652.5

0.5895 (normal approximation, corrected for ties)

\subsection{Buyers' reasons for commitment}

The buyers' reasons for commitment were obtained from sales-related supplier's news releases and announcements. Most news releases and announcements include quotes from the buyers indicating why they bought the product. All news releases and announcements were analyzed and a total of eight different reasons for buyers to commit were defined. Table 38 shows the keywords used to identify buyers' reasons to commit to UML-based development tools. Table 39 and figure 13 show the frequency distribution for buyers' reasons to commit to UML-based development tools. Table 40 shows buyers' reasons to commit to UML-based development tools categorical summary descriptive. 
Table 38 Buyers' reasons to commin keywords

\begin{tabular}{|l|l|}
\hline \multicolumn{1}{|c|}{ Buyers' reasons to commit } & \multicolumn{1}{c|}{ Keywords } \\
\hline Commit to open standards & Commit, open standard \\
\hline Cost reduction & Reduce cost \\
\hline Features provided & Features \\
\hline Openness / flexibility provided & Openness, flexible \\
\hline Reduce development cycle time & Reduce time \\
\hline Sponsor education activities & Sponsor, education \\
\hline Supplement application & Supplement, integrate \\
\hline Use for education purposes & Training, lab \\
\hline
\end{tabular}

Table 39 Frequency distribution for buyers' reasons to commit

\begin{tabular}{|l|c|c|}
\hline \multicolumn{1}{|c|}{ Buyers' reasons to commit } & Number & Percentage \\
\hline Commit to open standards & 2 & $3.51 \%$ \\
\hline Cost reduction & 2 & $3.51 \%$ \\
\hline Features provided & 23 & $40.35 \%$ \\
\hline Openness / flexibility provided & 12 & $21.05 \%$ \\
\hline Reduce development cycle time & 8 & $14.04 \%$ \\
\hline Sponsor education activities & 1 & $1.75 \%$ \\
\hline Supplement application & 7 & $12.28 \%$ \\
\hline Use for education purposes & 2 & $3.51 \%$ \\
\hline & 57 & $100.00 \%$ \\
\hline
\end{tabular}

Table 40 Duyers' reasons to commitment categorical summary descriptive

\begin{tabular}{r|l} 
Variable & Buyers' reason to commit \\
n & 57 \\
Groups & 8 \\
Mode & Features provided
\end{tabular}


Tigure 13 Frequency distribution for buyer's reasons to commitment

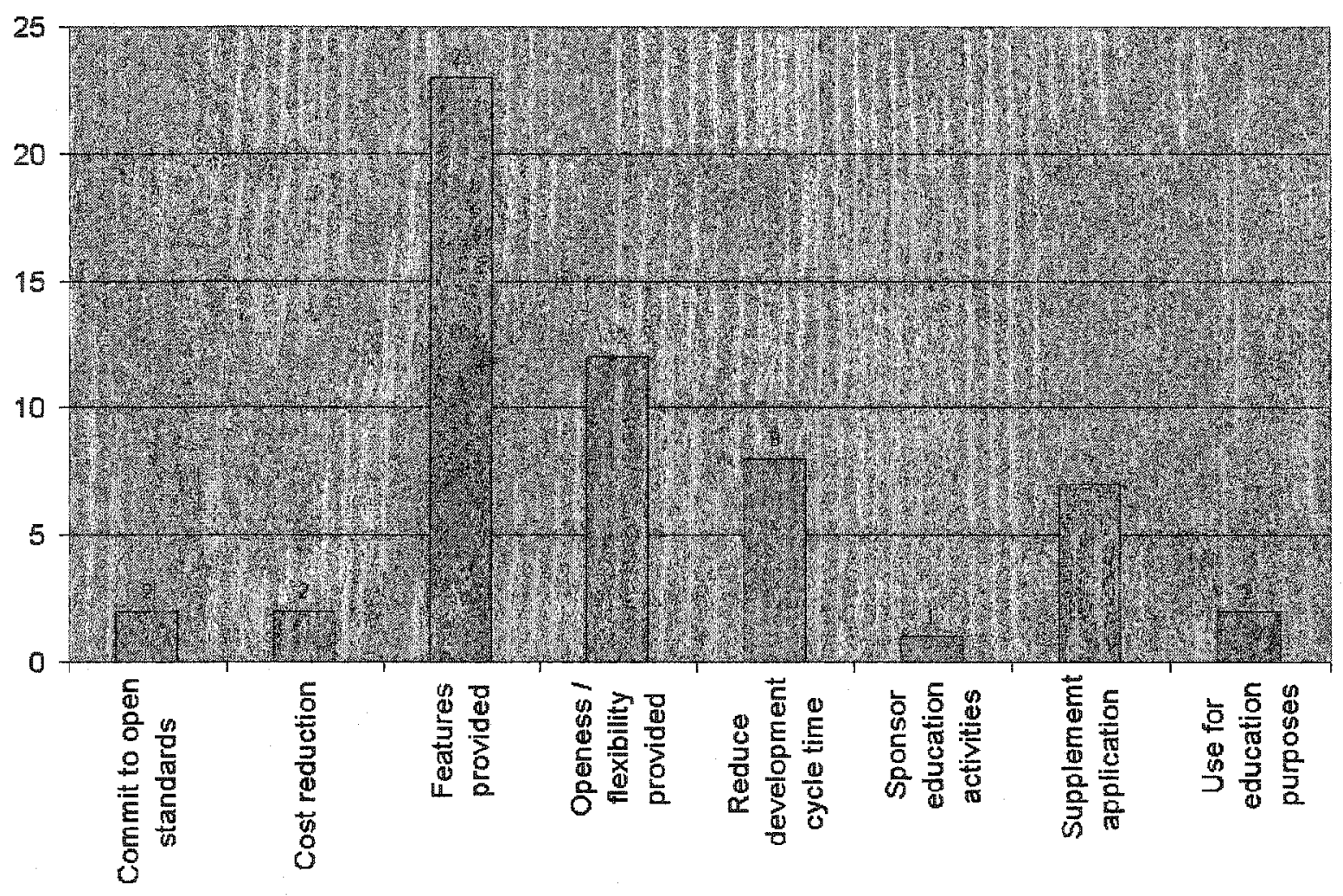

\subsection{Testing hypothesis $5 \mathrm{~b}$}

Hypothesis 5b: Reasons for which buyers commit to UML-based development tools are a function of the adoption stage. Test the association between the buyers' reasons to commit to UML-based development tools and the adoption stage.

Table 41 shows the results of using the Mann-Whitney U test comparing the buyers' reasons to commit at stages 1 and 2 . The results indicate that the mean rank of the supplier size at stage 1 is significantly larger than at stage 2. 
Table 1 Man-Whiney U test comparing buyers" reasons to commil between stages \begin{tabular}{r|c} 
Alternative hypothesis & Buyers' reasons to commit by stage: Stage $1 \neq$ Stage 2 \\
$n$ & 24
\end{tabular}

\begin{tabular}{r|r|r|r|r} 
Buyers' reasons by stage & n & Rank sum & Mean rank & U \\
\hline Stage 1 & 7 & 105.0 & 15.00 & 42.0 \\
Stage 2 & 17 & 195.0 & 11.47 & 77.0
\end{tabular}

Difference between medians $95.1 \% \mathrm{CI}$

Mann-Whitney U statistic 2-tailed p
42

0.2504 (normal approximation, corrected for ties)

Appendix XII provides the Mann-Whitney $U$ tests for the remaining pairs of stages. The results of all Mann-Whitney $U$ tests throw the following results:

- The mean rank of buyers' reasons to commit to UML-based development tools at stage 1 is significantly larger than the mean rank at stage 2 .

- The mean rank of buyers' reasons to commit to UML-based development tools at stage 2 is larger than the mean rank at stage 3.

- The mean rank of buyers' reasons to commit to UML-based development tools at stage 3 is larger than the mean rank at stage 4 .

The results support the acceptance of hypothesis $5 b$, suggesting that there is an association between the buyers' reasons to commit and the adoption stage. 


\section{Discussion of results}

This chapter is organized into seven sections. Section 6.1 states the research objectives and provides a summary of the results. Section 6.2 discusses results on the association between adoption stage and supplier size and product category. Section 6.3 discusses results on temporal patterns. Section 6.4 discusses results on the commitment to UML-based development tools. Section 6.5 discusses results on the suppliers' reasons to commit to UML-based development tools. Section 6.6 discusses results on buyers' reasons to commit to UML-based development tools. Section 6.7 presents the technology adoption life cycle for UML-based development tools.

\subsection{Objectives and summary of results}

The objectives of this research were to:

- Examine whether the stages of the life cycle affect supplier size and product category.

- Identify the temporal patterns of product diversity, supplier diversity, and buyer diversity as well as new suppliers' and buyers' entry rates.

- Identify the reasons for which suppliers and buyers commit to UML-based development tools.

Table 42 lists the results reported in Chapter 5. 
Table 42 Summary of results

\begin{tabular}{|c|c|c|}
\hline Hypothesis & Resullt & Rationale \\
\hline $\begin{array}{l}\text { H1: The size of a new supplier is } \\
\text { a function of the adoption stage. }\end{array}$ & Supported & $\begin{array}{l}\text { Results of the Mann-Whitney U test } \\
\text { show that the mean rank varies across } \\
\text { all adoption stages. } \\
\text { The results indicate that the mean rank } \\
\text { of the supplier size at stage } 1 \text { is } \\
\text { significantly larger than at stage } 2 ; \text { the } \\
\text { mean rank of the supplier size at stage } \\
2 \text { is significantly smaller than at stage } \\
3 \text {, the mean rank of the supplier size at } \\
\text { stage } 3 \text { is significantly smaller than at } \\
\text { stage } 4 \text {. }\end{array}$ \\
\hline $\begin{array}{l}\mathrm{H} 2 \text { : The type of a new product is } \\
\text { a function of the adoption stage. }\end{array}$ & Supported & $\begin{array}{l}\text { Results of the Mann-Whitney U test } \\
\text { show that the mean rank varies across } \\
\text { all adoption stages. } \\
\text { The results indicate that the mean rank } \\
\text { of the product type at stage } 1 \text { is } \\
\text { significantly smaller than at stage } 2 \text {; } \\
\text { the mean rank of the product type at } \\
\text { stage } 2 \text { is significantly smaller than at } \\
\text { stage } 3 \text {; the mean rank of the product } \\
\text { type at stage } 3 \text { is significantly larger } \\
\text { than at stage } 4 \text {. }\end{array}$ \\
\hline $\begin{array}{l}\text { H3a: Product diversity increases } \\
\text { rapidly during the early stages } \\
\text { then increases slowly towards } \\
\text { the later stages. }\end{array}$ & Supported & $\begin{array}{l}\text { Results of the Mann-Whitney U test } \\
\text { show that the mean rank varies across } \\
\text { all adoption stages. } \\
\text { The results indicate that the mean rank } \\
\text { of the product diversity at stage } 1 \text { is } \\
\text { significantly smaller than at stage } 2 \text {; } \\
\text { the mean rank of the product diversity } \\
\text { at stage } 2 \text { is significantly larger than at } \\
\text { stage } 3 \text {; the mean rank of the supplier } \\
\text { size at stage } 3 \text { is significantly larger } \\
\text { than at stage } 4 \text {. }\end{array}$ \\
\hline $\begin{array}{l}\text { H3b: Supplier diversity increases } \\
\text { rapidly during the early stages, } \\
\text { then increases slowly towards } \\
\text { the later stages. }\end{array}$ & Supported & $\begin{array}{l}\text { Results of the Mann-Whitney U test } \\
\text { show that the mean rank varies across } \\
\text { all adoption stages. }\end{array}$ \\
\hline $\begin{array}{l}\text { H3c. Buyer diversity increases } \\
\text { rapidly during the early stages } \\
\text { then increases slowly towards } \\
\text { the later stages. }\end{array}$ & Supported & $\begin{array}{l}\text { Results of the Mann-Whitney U test } \\
\text { show that the mean rank varies across } \\
\text { all adoption stages. }\end{array}$ \\
\hline
\end{tabular}




\begin{tabular}{|l|l|l|}
\hline Hypothesis & Resule & Tationale \\
\hline $\begin{array}{l}\text { H4a. The number of new buyers } \\
\text { will follow a bell shape } \\
\text { distribution. }\end{array}$ & Supported & $\begin{array}{l}\text { Results of the Mann-Whitney U test } \\
\text { show that the mean rank varies across } \\
\text { all adoption stages. }\end{array}$ \\
\hline $\begin{array}{l}\text { H4b. The number of new } \\
\text { suppliers will follow a bell shape } \\
\text { distribution. }\end{array}$ & $\begin{array}{l}\text { Not } \\
\text { supported }\end{array}$ & $\begin{array}{l}\text { Results of the Mann-Whitney U test } \\
\text { show that the mean rank does not } \\
\text { varies across all adoption stages. }\end{array}$ \\
\hline $\begin{array}{l}\text { H5a. The reason for which } \\
\text { suppliers commit to UML-based } \\
\text { development tools is a function } \\
\text { of the stage. }\end{array}$ & Supported & $\begin{array}{l}\text { Results of the Mann-Whitney U test } \\
\text { show that the mean rank varies across } \\
\text { all adoption stages. However the } \\
\text { association weakens as the adoption } \\
\text { process advances. }\end{array}$ \\
\hline $\begin{array}{l}\text { H5b. The reason for which } \\
\text { buyers commit to UML-based } \\
\text { development tools is a function } \\
\text { of the stage. }\end{array}$ & Supported & $\begin{array}{l}\text { Results of the Mann-Whitney U test } \\
\text { show that the mean rank varies across } \\
\text { all adoption stages. }\end{array}$ \\
\hline
\end{tabular}

\subsection{Association between adoption stage and supplier size and product category}

It was found that the suppliers that entered the UML-based development tools market in the earlier stages were much larger than those that entered the market at later stages. In contrast, Peng (2004) found that suppliers that entered the Linux market at an early stage were smaller than those that entered at later stages.

The results confirmed that:

- there is an association between adoption stage and supplier size

- there is an association between adoption stage and product category 


\subsection{Teminoral preterms}

It was found that the entry rate of new buyers follows a bell shape distribution, whereas the entry rate of new suppliers does not.

The supplier entry rate is slow at the initial stage then starts to increase rapidly. There is a period where the entry rate slows down then increases very rapidly again.

The buyer entry rate increases slowly then begins to increase more rapidly in the intermediate stages and then starts to level off and finally the buyer entry rate starts to decrease.

Based on the results, product diversity follows an S-curve shape as indicated by Geroski (2000). Product diversity grows rapidly during the early stages and then levels off at the later stages.

In the same manner, supplier diversity and buyer diversity follow an S-curve. Both grow rapidly during the early stages then level off at the later stages.

\subsection{Commitment to UVIL-based development tools}

It was found that there is a relationship between the adoption stages and the reasons for which suppliers commit to UML-based development tools. 
The results suggest that there is a relationship between the adoption stages and the reasons for which buyers commit to UML-based development tools.

\subsection{Suppliers' reasons to commit to UML-based development tools \\ The three most representative reasons for which suppliers commit to UML-based development tools are:}

- Add new features. $29 \%$ of the suppliers sample kept adding new features to their current products.

- Enter the market. $20.18 \%$ of the supplier sample was entering the market.

- Supplement applications. $17.43 \%$ of the supplier sample was supplementing their applications by integrating their products with other products. Suppliers of all sizes used two different means to supplement their applications and respond quickly to the market:

o by partnering with other suppliers

- by acquiring other suppliers 


\subsection{Buyers" reasons to commit to UML-based development tools}

The two most representative reasons for which buyers commit to UML-based development tools are:

- Features provided. $40.35 \%$ of the buyers acquired UML-based development tools for the set of features offered.

- Openness / flexibility provided. $21.05 \%$ of the buyers acquired UML-based development tools for the openness / flexibility provided by the products.

\subsection{UML-based development tools technology adoption life-cycle}

Figure 14 shows the technology adoption life-cycle for UML-based development tools over the study period based on: i) product, supplier, and buyer density; ii) state transitions based on product categories introduced by suppliers, percentage of buyer sample classified as users of the product category at each stage, and a minimum stage length of twelve months. 
Figure 14 UML-based development tools technology adoption life-cycle

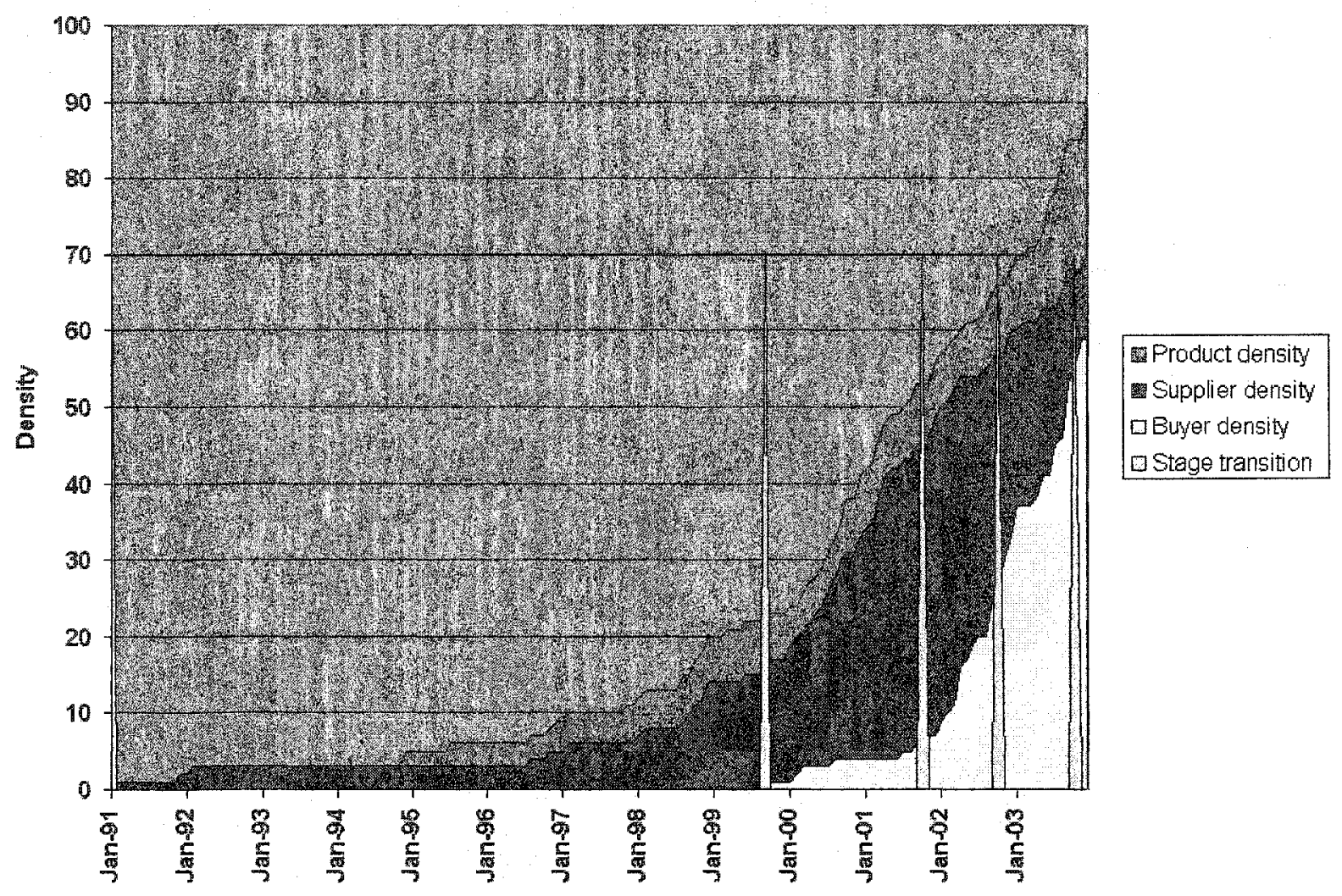

Figure 15 shows the technology adoption life-cycle for UML-based development tools over the study period based on: i) product, supplier, and buyer density; ii) state transitions based on product categories introduced by suppliers, percentage of buyer sample classified as users of the product category at each stage, and a minimum stage length of twelve months. 
Figure 15 A Atermate UML-based development tools techmology adontion life-cycle

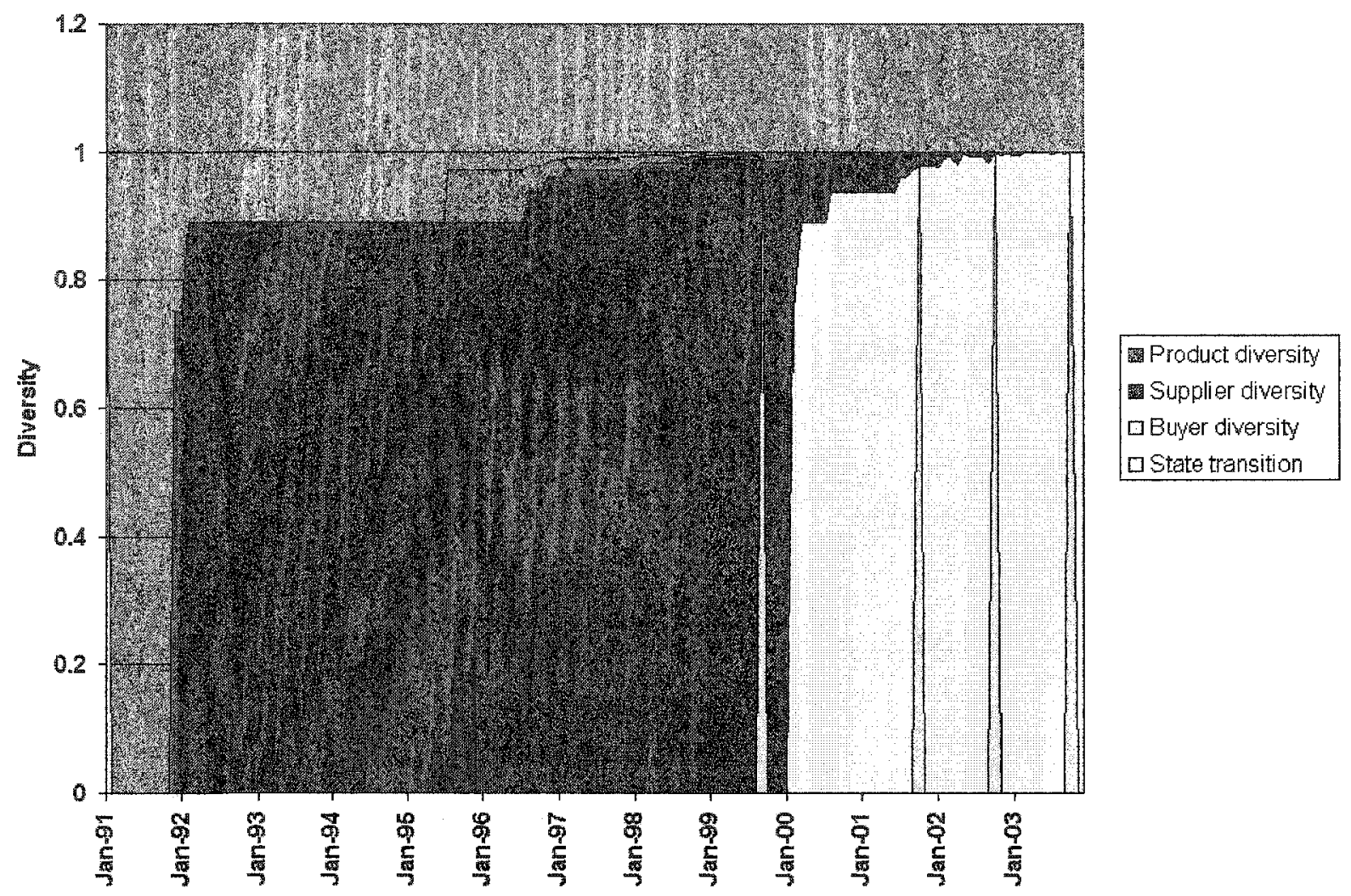




\section{Conclusions}

This chapter is organized into three sections. Section 7.1 provides the conclusions of the study. Section 7.2 describes the limitations of the research. Section 7.3 describes suggestions for future research.

\subsection{Conclusions}

The results of this research lead to the following conclusions:

- There is an association between the adoption stages and supplier size and product category. For UML driven-development tools domain, suppliers in the earlier stages are much larger than those that entered the market in later stages.

- The suppliers entry rate is slow during stages 1 and 2 , and faster during stages 3 and 4

- The buyers entry rate is slow during stages 1 and faster during stages 2,3 , and 4

- Supplier, product, and buyer diversity for the UML-based development tools domain follow an S-curve shape.

\subsection{Limitations of the Research}

The data used in the research is limited to information available in suppliers' and buyers' news releases and on the Business Source Premier database. Suppliers or buyers were not contacted to obtain data. As a result, data to measure supplier size was limited and the 
number of firms for which the information was obtained may not be representative of the entire population.

Suppliers' and buyers' revenue and employee data was not necessarily available for private companies and these companies represent the majority of the sample.

There is no way to know when buyers stop using UML-based development tools.

The underlying platforms on which products can be used were not taken into account.

\subsection{Suggestions for Future Research}

The following opportunities for future research were identified:

- In order to gain additional insights, researchers might consider testing the differences in suppliers and buyers strategic concerns.

- Expand the product categories to include the underlying platforms on which product can be used (e.g., Windows, Linux, Unix, multi-platform). This can provide additional insights to product managers when planning future development, and to top management teams for planning acquisitions and partnerships passed on buyers' platform requirements. 


\section{References}

Bunderson, J. Stuart and Kathleen M. Sutcliffe. 2002. Comparing Alternative Conceptualizations of Functional Diversity in Management Teams: Process and Performance Effects. Academy of Management Journal. Vol. 45. No. 5. 875-893.

Carlsson, Bo, Staffan Jacobsson, Magnus Holmén and Annika Rickne. 2002. Innovation systems: analytical and methodological issues. Research Policy 31. 233-245.

Debackere, Koenraad and Bart Clarysse. 1998. Advanced Bibliometric Methods to Model the Relationship between Entry Behaviour and Networking in Emerging Technological Communities. Journal of American Society for Information Science. 49(1): 49-58.

Geroski, P.A. 2000. Models of technology diffusion. Research Policy. 29: 603-625.

Hambrick, Donald C., Theresa Seung Cho, and Ming-Jer Chen. 1996. The Influence of Top Management Team Heterogeneity on Firms' Competitive Moves. Administrative Science Quarterly. 41.659-684.

Heiman, Richard. February 2003. Industry developments and models, ICD's Software taxonomy. IDC.

Joukhadar, Kristina. 2001. Design your application once, build it on any platform. InformationWeek. 87506874. 04/30/2001. Issue 835. Business Source Premier.

Kirzner, Rikki. 2003. Competitive analysis, worldwide analysis, modeling, design, and construction tools competitive analysis, 2003: 2002 shares and current outlook. IDC.

Klepper, Steven. 1996. Entry, Exit, Growth, and Innovation over the Product Life Cycle, American Economic Review. Vol. 86. No. 3. 562-583. 
Malerba, Franco. 2002. Sectoral systems of innovation and production. Research Policy 31: $247-264$

Malerba, Franco and Luigi Orsenigo. 2000. Knowledge, Innovative Activities and Industrial Evolution, Industrial and Corporate Change. Vol. 9. No. 2. 289-314.

Moore, Geoffrey. 2002. Living on the fault line. Harper Business. p132.

Peng, Zhezhi. 2004. Linux adoption by firms. Master's Thesis. Carleton University.

Rational Unified Process Glossary. 2003. Version 2003.06.0065.

Rogers, Everett M. 1983. Diffusion of Innovations, third edition, Free Press, New York.

Selic, Bran. 2003. The Pragmatics of UML-based development. IEEE Computer Society. $p$ 22.

Toncheva, Anna et al. 2002. Software Vendor's Guide to Vertical Markets in North America, 2000-2005, Part 2: Application development and deployment tools. IDC. 


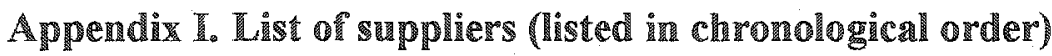

\begin{tabular}{|c|c|c|c|c|c|}
\hline Supplier & Product & Supplier type & $\begin{array}{l}\text { Revenue } \\
\text { (millions } \\
\text { \$US) }\end{array}$ & Employees & $\begin{array}{c}\text { Age } \\
\text { (years) }\end{array}$ \\
\hline MicroTOOL & ObjectiF & $\begin{array}{l}\text { Independent } \\
\text { software vendor }\end{array}$ & N/A & $\mathbb{N} / \mathbf{A}$ & 20 \\
\hline MID GmbH & Innovator & $\begin{array}{l}\text { Independent } \\
\text { software vendor }\end{array}$ & $\mathbb{N} / \mathbf{A}$ & 80 & 24 \\
\hline $\begin{array}{l}\text { Object Time } \\
\text { Limited }\end{array}$ & Object Tool & $\begin{array}{l}\text { Independent } \\
\text { software vendor }\end{array}$ & N/A & 140 & 8 \\
\hline $\begin{array}{l}\text { Microgold } \\
\text { Software }\end{array}$ & $\begin{array}{l}\text { WithClass } \\
\text { Professional }\end{array}$ & $\begin{array}{l}\text { Independent } \\
\text { software vendor }\end{array}$ & 10.2 & 80 & 19 \\
\hline Aonix & $\begin{array}{l}\text { Software through } \\
\text { Pictures UML }\end{array}$ & $\begin{array}{l}\text { Independent } \\
\text { software vendor }\end{array}$ & 8.3 & 65 & 8 \\
\hline Object Plant & Object Plant & $\begin{array}{l}\text { Independent } \\
\text { software vendor }\end{array}$ & N/A & N/A & 7 \\
\hline Telelogic & Tau UML Suite & $\begin{array}{l}\text { Independent } \\
\text { software vendor }\end{array}$ & 128.0 & 908 & 21 \\
\hline Rational Software & Rational Rose & $\begin{array}{l}\text { Independent } \\
\text { software vendor }\end{array}$ & 689.0 & 3561 & 24 \\
\hline Dia (Open Source) & Dia & Open Source & $\mathrm{N} / \mathrm{A}$ & $\mathrm{N} / \mathrm{A}$ & 6 \\
\hline Flashline Inc. & Flashline & $\begin{array}{l}\text { Independent } \\
\text { software vendor }\end{array}$ & 10.3 & 50 & 6 \\
\hline $\begin{array}{l}\text { Visual Object } \\
\text { Modelers }\end{array}$ & $\begin{array}{l}\text { Visual UML } \\
\text { Standard Edition }\end{array}$ & $\begin{array}{l}\text { Independent } \\
\text { software vendor }\end{array}$ & N/A & N/A & 6 \\
\hline Artisan & $\begin{array}{l}\text { Real-time Studio } \\
\text { Professional }\end{array}$ & $\begin{array}{l}\text { Independent } \\
\text { software vendor }\end{array}$ & 3.3 & 41 & 7 \\
\hline Memoire & Alma & Open Source & N/A & N/A & 6 \\
\hline No Magic Inc. & $\begin{array}{l}\text { MagicDraw UML } \\
\text { Standard }\end{array}$ & $\begin{array}{l}\text { Independent } \\
\text { software vendor }\end{array}$ & $\mathrm{N} / \mathrm{A}$ & N/A & 9 \\
\hline $\begin{array}{l}\text { MetaCase } \\
\text { Consulting }\end{array}$ & MetaEditt & $\begin{array}{l}\text { Independent } \\
\text { software vendor }\end{array}$ & N/A & $\mathrm{N} / \mathrm{A}$ & 13 \\
\hline $\begin{array}{l}\text { Tri-Pacific } \\
\text { Software }\end{array}$ & Rapid RMA & $\begin{array}{l}\text { Independent } \\
\text { software vendor }\end{array}$ & N/A & $\mathrm{N} / \mathrm{A}$ & 6 \\
\hline Softlab Limited & Visible Analyst 7.2 & $\begin{array}{l}\text { Independent } \\
\text { software vendor }\end{array}$ & N/A & N/A & 9 \\
\hline $\begin{array}{l}\text { Allen Systems } \\
\text { Group, Inc. }\end{array}$ & ASG-Rochade & $\begin{array}{l}\text { Independent } \\
\text { software vendor }\end{array}$ & 147.6 & 900 & 18 \\
\hline $\begin{array}{l}\text { Computer } \\
\text { Associates }\end{array}$ & $\begin{array}{l}\text { AllFusion } \\
\text { Component Modeler }\end{array}$ & $\begin{array}{l}\text { Independent } \\
\text { software vendor }\end{array}$ & 2934.0 & 16600 & 27 \\
\hline IntelliCorp, Inc. & $\begin{array}{l}\text { NetProcess } 5.2 \text { Tool } \\
\text { Suite }\end{array}$ & $\begin{array}{l}\text { Independent } \\
\text { software vendor }\end{array}$ & 11.6 & 120 & 24 \\
\hline Interactive Objects & $\begin{array}{l}\text { ArcStyler Personal } \\
\text { Edition }\end{array}$ & $\begin{array}{l}\text { Independent } \\
\text { software vendor }\end{array}$ & N/A & N/A & 14 \\
\hline Codagen & Codagen Architect & $\begin{array}{l}\text { Independent } \\
\text { software vendor }\end{array}$ & $\mathrm{N} / \mathrm{A}$ & N/A & 5 \\
\hline MetaMatrix & MetaBase Modeler & $\begin{array}{l}\text { Independent } \\
\text { software vendor }\end{array}$ & N/A & N/A & 6 \\
\hline
\end{tabular}




\begin{tabular}{|c|c|c|c|c|c|}
\hline Supplier & Product & Supplier type & $\begin{array}{l}\text { Revenue } \\
\text { (millions } \\
\text { \$US) }\end{array}$ & Employees & $\begin{array}{c}\text { Age } \\
\text { (years) }\end{array}$ \\
\hline Oracle & Developer & $\begin{array}{l}\text { Independent } \\
\text { software vendor }\end{array}$ & 9475.0 & 40650 & 27 \\
\hline Unimodeller & Unimodeller & Open Source & $\mathrm{N} / \mathrm{A}$ & $\mathrm{N} / \mathrm{A}$ & 1 \\
\hline Ideogramic & $\begin{array}{l}\text { Ideogramic UML, } \\
\text { Desktop Edition }\end{array}$ & $\begin{array}{l}\text { Independent } \\
\text { software vendor }\end{array}$ & N/A & N/A & 4 \\
\hline Visible Systems & Visible Analyst & $\begin{array}{l}\text { Independent } \\
\text { software vendor }\end{array}$ & 5.3 & 40 & 23 \\
\hline Sparx Systems & $\begin{array}{l}\text { Enterprise Architect } \\
\text { Professional }\end{array}$ & $\begin{array}{l}\text { Independent } \\
\text { software vendor }\end{array}$ & N/A & N/A & 4 \\
\hline Modelistic & Modelistic & $\begin{array}{l}\text { Independent } \\
\text { software vendor }\end{array}$ & N/A & N/A & 6 \\
\hline $\begin{array}{l}\text { Project } \\
\text { Technology }\end{array}$ & BridgePoint & $\begin{array}{l}\text { Independent } \\
\text { software vendor }\end{array}$ & $\mathrm{N} / \mathrm{A}$ & N/A & 20 \\
\hline $\begin{array}{l}\text { Mega } \\
\text { International }\end{array}$ & Mega Designer & $\begin{array}{l}\text { Independent } \\
\text { software vendor }\end{array}$ & 10.0 & 11 & 13 \\
\hline EctoSet & EctoSet Modeller & $\begin{array}{l}\text { Independent } \\
\text { software vendor }\end{array}$ & $\mathrm{N} / \mathrm{A}$ & N/A & 4 \\
\hline Microcross Inc. & Visual GNU X-Tools & $\begin{array}{l}\text { Independent } \\
\text { software vendor }\end{array}$ & N/A & N/A & 4 \\
\hline Borland & $\begin{array}{l}\text { Delphi Studio } \\
\text { Architect }\end{array}$ & $\begin{array}{l}\text { Independent } \\
\text { software vendor }\end{array}$ & 295236.0 & 1358 & 19 \\
\hline Novosoft LLC. & Novosoft LLC. & Open Source & N/A & $\mathrm{N} / \mathrm{A}$ & 12 \\
\hline Microsoft & $\begin{array}{l}\text { Visual Studio .NET } \\
\text { Enterprise Architect }\end{array}$ & $\begin{array}{l}\text { Independent } \\
\text { software vendor }\end{array}$ & 0.64 & 5 & 8 \\
\hline Microsoft Visio & $\begin{array}{l}\text { Visio } 2002 \\
\text { Professional }\end{array}$ & $\begin{array}{l}\text { Independent } \\
\text { software vendor }\end{array}$ & 25.3 & 50000 & 28 \\
\hline Sybase & PowerDesigner & $\begin{array}{l}\text { Independent } \\
\text { software vendor }\end{array}$ & 926.1 & 4639 & 20 \\
\hline $\begin{array}{l}\text { Quest Software, } \\
\text { Inc. }\end{array}$ & Qdesigner & $\begin{array}{l}\text { Independent } \\
\text { software vendor }\end{array}$ & 254.4 & 1642 & 17 \\
\hline $\begin{array}{l}\text { Select Business } \\
\text { Solutions }\end{array}$ & Component Architect & $\begin{array}{l}\text { Independent } \\
\text { software vendor }\end{array}$ & N/A & N/A & 3 \\
\hline Excel Software & Quick UML & $\begin{array}{l}\text { Independent } \\
\text { software vendor }\end{array}$ & N/A & N/A & 19 \\
\hline Eldean $\mathrm{AB}$ & ESS-Model & $\begin{array}{l}\text { Independent } \\
\text { software vendor }\end{array}$ & $\mathrm{N} / \mathrm{A}$ & $\mathrm{N} / \mathrm{A}$ & 3 \\
\hline Popkin & System Architect & $\begin{array}{l}\text { Independent } \\
\text { software vendor }\end{array}$ & 11.1 & 50 & 18 \\
\hline ProxySource & ProxyDesigner & $\begin{array}{l}\text { Independent } \\
\text { software vendor }\end{array}$ & 0.512 & 4 & 4 \\
\hline Embarcadero & Describe & $\begin{array}{l}\text { Independent } \\
\text { software vendor }\end{array}$ & 49.0 & 286 & 8 \\
\hline Eclipse & Eclipse platform & Open Source & $\mathrm{N} / \mathrm{A}$ & $\mathrm{N} / \mathrm{A}$ & 6 \\
\hline
\end{tabular}




\begin{tabular}{|c|c|c|c|c|c|}
\hline Supplier & Product & Supplier type & $\begin{array}{c}\text { Revenue } \\
\text { (millions } \\
\$ \text { US ) }\end{array}$ & Employees & $\begin{array}{c}\text { Age } \\
\text { (years) }\end{array}$ \\
\hline Eiffel Software Inc & Eiffel Studio & $\begin{array}{l}\text { Independent } \\
\text { software vendor }\end{array}$ & 5.0 & 27 & 19 \\
\hline Fujaba & Fuiaba & University & $N / A$ & N/A & 7 \\
\hline $\begin{array}{l}\text { Objective Ideas } \\
\mathrm{AB}\end{array}$ & JSequence & $\begin{array}{l}\text { Independent } \\
\text { software vendor }\end{array}$ & N/A & $\mathrm{N} / \mathrm{A}$ & 15 \\
\hline MKS Inc. & $\begin{array}{l}\text { MKS Integrity } \\
\text { Solution }\end{array}$ & $\begin{array}{l}\text { Independent } \\
\text { software vendor }\end{array}$ & 31.9 & 248 & 19 \\
\hline Logic Explorers & Code Logic & $\begin{array}{l}\text { Independent } \\
\text { software vendor }\end{array}$ & N/A & $\mathrm{N} / \mathrm{A}$ & 2 \\
\hline Kennedy-Carter & iUML & $\begin{array}{l}\text { Independent } \\
\text { software vendor }\end{array}$ & N/A & N/A & 3 \\
\hline $\begin{array}{l}\text { Proforma } \\
\text { Corporation }\end{array}$ & ProVision & $\begin{array}{l}\text { Independent } \\
\text { software vendor }\end{array}$ & 6.0 & 44 & 10 \\
\hline SlickEdit Inc. & SlickEdit v7.0 & $\begin{array}{l}\text { Independent } \\
\text { software vendor }\end{array}$ & N/A & N/A & 4 \\
\hline yWorks & yDoc & $\begin{array}{l}\text { Independent } \\
\text { software vendor }\end{array}$ & N/A & $\mathrm{N} / \mathrm{A}$ & 6 \\
\hline Artiso & Artiso Visual Case & $\begin{array}{l}\text { Independent } \\
\text { software vendor }\end{array}$ & N/A & N/A & 4 \\
\hline Omondo & Omondo & Open Source & N/A & N/A & 2 \\
\hline Compuware & OptimalJ & $\begin{array}{l}\text { Independent } \\
\text { software vendor }\end{array}$ & 1264.0 & 9356 & 31 \\
\hline SAP AG & SAP NetWeaver & $\begin{array}{l}\text { Independent } \\
\text { software vendor }\end{array}$ & 8831.0 & 30251 & 30 \\
\hline Visual Paradigm & $\begin{array}{l}\text { Visual Paradigm for } \\
\text { UML }\end{array}$ & $\begin{array}{l}\text { Independent } \\
\text { software vendor }\end{array}$ & N/A & $\mathrm{N} / \mathrm{A}$ & 2 \\
\hline Tigris org & ArgoUML & Open Source & N/A & N/A & 1 \\
\hline CanyonBlue & Konesa Modeler & $\begin{array}{l}\text { Independent } \\
\text { software vendor }\end{array}$ & N/A & $\mathrm{N} / \mathrm{A}$ & 1 \\
\hline Gentleware & $\begin{array}{l}\text { Poseidon for UML - } \\
\text { Community }\end{array}$ & $\begin{array}{l}\text { Independent } \\
\text { software vendor }\end{array}$ & N/A & $\mathrm{N} / \mathrm{A}$ & 4 \\
\hline Metanology & $\mathrm{MDE}$ for $\mathrm{UML}$ & $\begin{array}{l}\text { Independent } \\
\text { software vendor }\end{array}$ & $\mathrm{N} / \mathrm{A}$ & $\mathrm{N} / \mathrm{A}$ & 4 \\
\hline Insoft & $\begin{array}{l}\text { Prosa 2004 UML } \\
\text { Modeler }\end{array}$ & $\begin{array}{l}\text { Independent } \\
\text { software vendor }\end{array}$ & N/A & $\mathrm{N} / \mathrm{A}$ & 17 \\
\hline I-Logix & $\begin{array}{l}\text { Rhapsody Developer } \\
\text { Edition }\end{array}$ & $\begin{array}{l}\text { Independent } \\
\text { software vendor }\end{array}$ & 14.7 & 110 & 17 \\
\hline IDS Scheer AG & Aris UML Designer & $\begin{array}{l}\text { Independent } \\
\text { software vendor }\end{array}$ & 179821.0 & 2011 & 20 \\
\hline Object Club & Jude Bamboo & Open Source & $\mathrm{N} / \mathrm{A}$ & N/A & 5 \\
\hline IBM-Rational & $\begin{array}{l}\text { Rose XDE } \\
\text { Developer for Visual } \\
\text { Studio }\end{array}$ & $\begin{array}{l}\text { Independent } \\
\text { software vendor }\end{array}$ & 89000.0 & 255157 & 80 \\
\hline Magna Solutions & $\begin{array}{l}\text { Silverrun } \\
\text { ModelSphere }\end{array}$ & $\begin{array}{l}\text { Independent } \\
\text { software vendor }\end{array}$ & $\mathrm{N} / \mathrm{A}$ & N/A & 1 \\
\hline
\end{tabular}


Appendix II. List of buyers

\begin{tabular}{|c|c|c|c|c|}
\hline Buyer name & Vertical market & $\begin{array}{c}\text { Revenue } \\
\text { (millions \$ US) }\end{array}$ & Employees & $\begin{array}{c}\text { Age } \\
\text { (years) }\end{array}$ \\
\hline $\begin{array}{l}\text { Accelerated } \\
\text { Technology, Inc., }\end{array}$ & $\begin{array}{l}\text { Application design } \\
\text { and construction tools }\end{array}$ & 0.9 & 12 & 14 \\
\hline $\begin{array}{l}\text { Arizona Supreme Court } \\
\text { in Phoenix }\end{array}$ & Government & & & \\
\hline Audi Group & $\begin{array}{l}\text { Automotive } \\
\text { manufacturing }\end{array}$ & 29097.0 & 52689 & \\
\hline Austrian Aerospace & Telecommunications & & & 7 \\
\hline BAE Systems & Other services & 14911.0 & 68400 & \\
\hline $\begin{array}{l}\text { Banco Nossa Caixa } \\
\text { S.A. }\end{array}$ & Banking & & & \\
\hline $\begin{array}{l}\text { BMT Defence Services } \\
\text { Limited }\end{array}$ & Transportation & & & 16 \\
\hline Broadband Storage & Other services & & & 4 \\
\hline $\begin{array}{l}\text { Catalist Systems } \\
\text { Corporation }\end{array}$ & $\begin{array}{l}\text { Application design } \\
\text { and construction tools }\end{array}$ & & & \\
\hline $\begin{array}{l}\text { Central Florida } \\
\text { Investments Inc. }\end{array}$ & Other services & & & \\
\hline $\begin{array}{l}\text { Conti Temic } \\
\text { Microelectronic } \mathrm{GmbH}\end{array}$ & $\begin{array}{l}\text { Discrete } \\
\text { manufacturing }\end{array}$ & & & 12 \\
\hline Dell Computer Corp & $\begin{array}{l}\text { Discrete } \\
\text { manufacturing }\end{array}$ & 31168.0 & 34600 & 20 \\
\hline Department of Defense & Government & & & \\
\hline DESE Research Inc & Other services & & & 22 \\
\hline $\begin{array}{l}\text { EADS Deutschland } \\
\text { GMBH }\end{array}$ & Government & & & 4 \\
\hline $\begin{array}{l}\text { Embarcadero } \\
\text { Technologies Inc. }\end{array}$ & $\begin{array}{l}\text { Application design } \\
\text { and construction tools }\end{array}$ & 24.7 & 274 & 11 \\
\hline $\begin{array}{l}\text { Fidelity National } \\
\text { Financial }\end{array}$ & Financial services & 5083.0 & 17600 & 157 \\
\hline
\end{tabular}




\begin{tabular}{|c|c|c|c|c|}
\hline Buyer name & Vertical market & $\begin{array}{c}\text { Revenue } \\
\text { (millions \$US) }\end{array}$ & Employees & $\begin{array}{c}\text { Age } \\
\text { (years) }\end{array}$ \\
\hline General Motors & $\begin{array}{l}\text { Automotive } \\
\text { manufacturing }\end{array}$ & 186763.0 & 355000 & 96 \\
\hline $\begin{array}{l}\text { Green Hills Software } \\
\text { Inc. }\end{array}$ & $\begin{array}{l}\text { Application design } \\
\text { and construction tools }\end{array}$ & 51.0 & 185 & 22 \\
\hline $\begin{array}{l}\text { HART Communication } \\
\text { Foundation }\end{array}$ & Other services & & & 11 \\
\hline Hewlett Packard & $\begin{array}{l}\text { Application design } \\
\text { and construction tools }\end{array}$ & 76061.0 & 142000 & 65 \\
\hline $\begin{array}{l}\text { Intertech Consulting } \\
\text { Inc. }\end{array}$ & Other services & & & \\
\hline $\begin{array}{l}\text { Investec Asset } \\
\text { Management }\end{array}$ & Financial services & & & 32 \\
\hline $\begin{array}{l}\text { Junior Achievement } \\
\text { Inc. }\end{array}$ & Other services & & & 85 \\
\hline KEMA Consulting & Other services & 150.0 & 1471 & 30 \\
\hline $\begin{array}{l}\text { Leopold Kostal GmbH } \\
\& \text { Co. KG }\end{array}$ & $\begin{array}{l}\text { Automotive } \\
\text { manufacturing }\end{array}$ & & 9480 & 92 \\
\hline Lockheed Martin & $\begin{array}{l}\text { Engineering / } \\
\text { management }\end{array}$ & 1289.0 & 125000 & 9 \\
\hline $\begin{array}{l}\text { Lucent Technologies } \\
\text { Inc. }\end{array}$ & Telecommunications & 33577.0 & 30000 & 8 \\
\hline Matra Marconi Space & Transportation & 8400.0 & 5000 & 14 \\
\hline $\begin{array}{l}\text { Metanology } \\
\text { Corporation }\end{array}$ & $\begin{array}{l}\text { Application design } \\
\text { and construction tools }\end{array}$ & & & \\
\hline Microcross, Inc. & $\begin{array}{l}\text { Application design } \\
\text { and construction tools }\end{array}$ & & & 4 \\
\hline MicroGold Software & $\begin{array}{l}\text { Application design } \\
\text { and construction tools }\end{array}$ & 0.64 & 5 & 8 \\
\hline
\end{tabular}




\begin{tabular}{|c|c|c|c|c|}
\hline Buyer name & Vertical market & $\begin{array}{c}\text { Revenue } \\
\text { (millions \$US) }\end{array}$ & Employees & $\begin{array}{c}\text { Age } \\
\text { (years) }\end{array}$ \\
\hline MKS Inc. & $\begin{array}{l}\text { Application life } \\
\text { cycle-management }\end{array}$ & 31.9 & 248 & 20 \\
\hline Nissan & $\begin{array}{l}\text { Automotive } \\
\text { manufacturing }\end{array}$ & 61477.0 & 31128 & 71 \\
\hline $\begin{array}{l}\text { Northern Alberta } \\
\text { Institute of Technology }\end{array}$ & Education & & & 42 \\
\hline $\begin{array}{l}\text { Omicron } \\
\text { NanoTechnology } \\
\text { GmbH }\end{array}$ & $\begin{array}{l}\text { Engineering / } \\
\text { management }\end{array}$ & & & 20 \\
\hline $\begin{array}{l}\text { Optiz Consulting } \\
\text { GmbH }\end{array}$ & Other services & & & \\
\hline Power3, LLC & Other services & & & \\
\hline Raytheon Company & Transportation & 18109.0 & 78000 & 82 \\
\hline Saab Automobile $\mathrm{AB}$ & $\begin{array}{l}\text { Automotive } \\
\text { manufacturing }\end{array}$ & 3143.0 & 8358 & 67 \\
\hline Scapa Technologies & $\begin{array}{l}\text { Application design } \\
\text { and construction tools }\end{array}$ & & & 6 \\
\hline Softier Inc. & $\begin{array}{l}\text { Application design } \\
\text { and construction tools }\end{array}$ & & & 2 \\
\hline SPAR Handels AG & $\begin{array}{l}\text { Agriculture / } \\
\text { construction }\end{array}$ & 6822.0 & 35535 & \\
\hline Sun Microsystems, Inc. & $\begin{array}{l}\text { Information access } \\
\text { and delivery }\end{array}$ & 12500.0 & 39400 & 22 \\
\hline $\begin{array}{l}\text { TANDBERG } \\
\text { Television }\end{array}$ & $\begin{array}{l}\text { Broadcast and other } \\
\text { communications }\end{array}$ & 263.0 & 512 & 71 \\
\hline Tele Atlas & $\begin{array}{l}\text { Information and data } \\
\text { management }\end{array}$ & 67.9 & 1850 & 20 \\
\hline $\begin{array}{l}\text { TeleManagement } \\
\text { Forum }\end{array}$ & Telecommunications & & & 16 \\
\hline The National Trust & Other services & & & 109 \\
\hline
\end{tabular}




\begin{tabular}{|l|l|c|c|c|}
\hline Buyer name & Vertical market & $\begin{array}{c}\text { Revenue } \\
\text { (millions \$ US) }\end{array}$ & Employees & $\begin{array}{c}\text { Age } \\
\text { (years) }\end{array}$ \\
\hline The Peace Corps & Government & & 43 \\
\hline $\begin{array}{l}\text { Visible Systems } \\
\text { Corporation }\end{array}$ & $\begin{array}{l}\text { Application design } \\
\text { and construction tools }\end{array}$ & 5.30 & 40.0 & 23 \\
\hline $\begin{array}{l}\text { Vodafone Global } \\
\text { Products and Services }\end{array}$ & Telecommunications & 47962.0 & 66667 & 20 \\
\hline $\begin{array}{l}\text { Yellow Roadway } \\
\text { Corporation }\end{array}$ & Other services & 2811.90 & 25000.0 & 80 \\
\hline
\end{tabular}




\section{Appendix III. Testing hypothesis 1}

Testing hypothesis 1: The size of new supplier is a function of the adoption stage (MannWhitney U test).

Comparing stages 1 and 2:
$\mathrm{n}$
(cases excluded: 33 due to 23 missing values)

\begin{tabular}{r|r|r|r|r} 
Revenue by Stage & \multicolumn{1}{c|}{$\mathrm{n}$} & Rank sum & Mean rank & $\mathrm{U}$ \\
\hline Stage 1 & 20 & 252.0 & 12.60 & 18.0 \\
Stage 2 & 3 & 24.0 & 8.00 & 42.0
\end{tabular}

\begin{tabular}{r|rc}
$\begin{array}{r}\text { Difference between } \\
\text { medians }\end{array}$ & - & \\
$95 \% \mathrm{CI}$ & - & to - \\
Mann-Whitney U & & \\
statistic & 18 & \\
2-tailed p & $0.1846 \quad$ for ties)
\end{tabular}


Comparing stages 2 and 3 :

$$
\mathrm{n} \mid \begin{aligned}
& \text { (cases excluded: } 16 \text { due to } \\
& \text { missing values) }
\end{aligned}
$$

\begin{tabular}{r|r|r|r|r} 
Revenue by Stage & $\mathrm{n}$ & Rank sum & Mean rank & \multicolumn{1}{c}{$\mathrm{U}$} \\
\hline Stage 2 & 3 & 7.5 & 2.50 & 10.5 \\
Stage 3 & 4 & 20.5 & 5.13 & 1.5
\end{tabular}

$\begin{array}{r}\text { Difference between } \\ \text { medians } \\ 95 \% \mathrm{CI}\end{array} \mid$

\begin{tabular}{|c|c|}
\hline $\begin{array}{r}\text { Mann-Whitney U } \\
\text { statistic }\end{array}$ & 10.5 \\
\hline 2-tailed $p$ & 0.2286 ties) \\
\hline
\end{tabular}


Comparing stages 3 and 4 :

$$
\text { n } 5 \text { values) }
$$

\begin{tabular}{r|r|r|r|r} 
Revenue by Stage & $\mathrm{n}$ & Rank sum & Mean rank & $\mathrm{U}$ \\
\hline Stage 3 & 4 & 11.5 & 2.88 & 2.5 \\
Stage 4 & 1 & 3.5 & 3.50 & 1.5
\end{tabular}

$\begin{array}{r}\text { Difference between } \\ \text { medians } \\ 95 \% \mathrm{CI}\end{array} \mid \begin{aligned} & \\ & -\end{aligned}$

$$
\begin{array}{r|rr}
\text { Mann-Whitney U } & & \\
\text { statistic } & 2.5 & \\
\text { 2-tailed p } & 0.8000 & \text { (exact tables used, 80\% ties) }
\end{array}
$$


Append: IV. List of products

\begin{tabular}{|l|l|l|}
\hline \multicolumn{1}{|c|}{ Product } & \multicolumn{1}{|c|}{ Supplier } & \multicolumn{1}{c|}{ Product type } \\
\hline AllFusion Component Modeler & Computer Associates & Product suite \\
\hline AndroMDA & AndroMDA & Forward-engineering \\
\hline AnyStates & XJ Technologies & Forward-engineering \\
\hline ArcStyler Personal Edition & Interactive Objects & Forward-engineering \\
\hline ArgoUML & Tigris & Reverse-engineering \\
\hline Artiso Visual Case & Artiso & Round-trip engineering \\
\hline BridgePoint & Project Technology & Forward-engineering \\
\hline Codagen Architect & Codagen & Forward-engineering \\
\hline Code Logic & Logic Explorers & Reverse-engineering \\
\hline & Select Business & \\
Component Architect & Solutions & Product suite \\
\hline Delphi Studio Architect & Borland & Forward-engineering \\
\hline Describe & Embarcadero & Product suite \\
\hline Dia & Dia & Modeling only \\
\hline EclipseUML & Omondo & Modeling only \\
\hline EctoSet Modeller & EctoSet & Forward-engineering \\
\hline Eiffel Studio & Eiffel Software Inc & Forward-engineering \\
\hline Enterprise Architect Professional & Sparx Systems & Round-trip engineering \\
\hline ESS-Model & Eldean AB & Reverse-engineering \\
\hline FL & Novosoft & Forward-engineering \\
\hline Fujaba & Fujaba & Round-trip engineering \\
\hline Holocentric Modeler & Prism International & Product suite \\
\hline Ideogramic UML, Desktop Edition & Ideogramic & Reverse-engineering \\
\hline INNOVATOR & MID GmbH & Forward-engineering \\
\hline iUML & Kennedy-Carter & Forward-engineering \\
\hline J2U & Nasra Consulting & Reverse-engineering \\
\hline JDeveloper & Oracle & Round-trip engineering \\
\hline JSequence & Objective Ideas AB & Reverse-engineering \\
\hline Jude Bamboo & Jude & Reverse-engineering \\
\hline JVISION & Object Insight & Reverse-engineering \\
\hline Konesa Modeler & CanyonBlue & Round-trip engineering \\
\hline MagicDraw UML Enterprise & No Magic Inc. & Product suite \\
\hline MagicDraw UML Professional & No Magic Inc. & Round-trip engineering \\
\hline MagicDraw UML Standard & No Magic Inc. & Modeling only \\
\hline & & \\
\hline
\end{tabular}




\begin{tabular}{|c|c|c|}
\hline Product & Supplier & Product type \\
\hline MDE for EJB & Metanology & Forward-engineering \\
\hline $\mathrm{MDE}$ for $\mathrm{J} 2 \mathrm{EE}$ & Metanology & Forward-engineering \\
\hline MDE for UML & Metanology & Modeling only \\
\hline Mega Designer & Mega International & Round-trip engineering \\
\hline MetaBase Modeler & MetaMatrix & Modeling only \\
\hline MetaEdit+ & MetaCase Consulting & Modeling only \\
\hline Metamill & Metamill Software & Round-trip engineering \\
\hline MIA-Generation Architect Edition & Model-in-Action & Forward-engineering \\
\hline MIA-Generation Developer Edition & Model-in-Action & Forward-engineering \\
\hline Modelistic & Modelistic & Round-trip engineering \\
\hline ModelMaker & ModelMaker Tools & Round-trip engineering \\
\hline Novosoft UML Library & Novosoft & Modeling only \\
\hline Object Domain Standard & $\begin{array}{l}\text { Object Domain } \\
\text { Systems }\end{array}$ & Round-trip engineering \\
\hline Object Plant & Object Plant & Forward-engineering \\
\hline Object Tool & Object Time Limited & Forward-engineering \\
\hline Object ToolSet & Object Time Limited & Forward-engineering \\
\hline Objecteering Personal Edition & Softeam & Forward-engineering \\
\hline ObjectiF & MicroTOOL & Forward-engineering \\
\hline ObjecTime Developer & Object Time Limited & Round-trip engineering \\
\hline OptimalJ & Compuware & Forward-engineering \\
\hline Poseidon for UML - Community & Gentleware & Forward-engineering \\
\hline Poseidon for UML - Professional & Gentleware & Round-trip engineering \\
\hline Poseidon for UML - Standard & Gentleware & Forward-engineering \\
\hline PowerDesigner & Sybase & Round-trip engineering \\
\hline Prosa 2004 UML Modeler & Insoft & Forward-engineering \\
\hline ProVision & Proforma Corporation & Modeling only \\
\hline ProxyDesigner & ProxySource & Modeling only \\
\hline Quick UML & Excel Software & Modeling only \\
\hline Rapid RMA & Tri-Pacific Software & Modeling only \\
\hline Rational Rose $98(4.5)$ & Rational Software & Round-trip engineering \\
\hline Rational Rose Real Time $2000 \mathrm{e}$ & Rational Software & Round-trip engineering \\
\hline Rational Rose Real Time 2002.05.00 & Rational Software & Round-trip engineering \\
\hline Rational Rose Real Time 6.0 & Rational Software & Round-trip engineering \\
\hline Real-time Studio Professional & Artisan & Round-trip engineering \\
\hline Rhapsody Developer Edition & I-Logix & Product suite \\
\hline Rose Technical Developer & IBM-Rational & Modeling only \\
\hline
\end{tabular}




\begin{tabular}{|l|l|l|}
\hline \multicolumn{1}{|c|}{ Product } & \multicolumn{1}{|c|}{ Supplier } & \multicolumn{1}{c|}{ Product type } \\
\hline Rose XDE Developer for Java & IBM-Rational & Product suite \\
\hline $\begin{array}{l}\text { Rose XDE Developer for Visual } \\
\text { Studio }\end{array}$ & BBM-Rational & Product suite \\
\hline Silverrun ModelSphere & Magna Solutions & Round-trip engineering \\
\hline Software through Pictures UML & Aonix & Forward-engineering \\
\hline System Architect & Popkin & Product suite \\
\hline Tau UML Suite & Telelogic & Product suite \\
\hline Together Control Center & TogetherSoft & Round-trip engineering \\
\hline Umbrello UML Modeller & Umbrello & Modeling only \\
\hline UML Diagrammer & Pacestar & Modeling only \\
\hline UML Studio & Pragsoft Corporation & Round-trip engineering \\
\hline UMLGraph & UMLGraph & Reverse-engineering \\
\hline UMT-QVT & UMT-QVT & Forward-engineering \\
\hline Unimodeler & Unimodeler & Modeling only \\
\hline Visible Analyst & Visible Systems & Modeling only \\
\hline Visio 2002 Professional & Microsoft Visio & Reverse-engineering \\
\hline Visual Paradigm for UML & Visual Paradigm & Modeling only \\
\hline $\begin{array}{l}\text { Visual Studio .NET Enterprise } \\
\text { Architect }\end{array}$ & Microsoft & Modeling only \\
\hline Visual UML Standard Edition & $\begin{array}{l}\text { Visual Object } \\
\text { Modelers }\end{array}$ & Round-trip engineering \\
\hline WithClass Professional & Microgold Software & Forward-engineering \\
\hline yDoc & yWorks & Reverse-engineering \\
\hline
\end{tabular}




\section{Appendix V. Testing hypothesis 2}

Testing hypothesis 2: The type of new product is a function of the adoption stage (MannWhitney $U$ test).

Comparing stages 1 and 2:

$$
\mathrm{n} \mid 25
$$

\begin{tabular}{r|r|r|r|r} 
Product type by Stage & $\mathrm{n}$ & $\begin{array}{c}\text { Rank } \\
\text { sum }\end{array}$ & $\begin{array}{c}\text { Mean } \\
\text { rank }\end{array}$ & \multicolumn{1}{c}{$\mathrm{U}$} \\
\hline Stage 1 & 6 & 81.5 & 13.58 & 53.5 \\
Stage 2 & 19 & 243.5 & 12.82 & 60.5
\end{tabular}

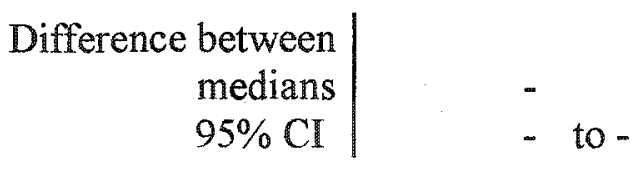

\begin{tabular}{r|rl}
$\begin{array}{r}\text { Mann-Whitney U } \\
\text { statistic }\end{array}$ & 53.5 & \\
2-tailed p & 0.8165 & (normal approximation, \\
corrected for ties)
\end{tabular}


Comparing stages 2 and 3 :

n 147

\begin{tabular}{r|r|r|r|r} 
Product type by Stage & $\mathrm{n}$ & $\begin{array}{c}\text { Rank } \\
\text { sum }\end{array}$ & $\begin{array}{c}\text { Mean } \\
\text { rank }\end{array}$ & \multicolumn{1}{c}{$\mathrm{U}$} \\
\hline Stage 2 & 19 & 479.5 & 25.24 & 242.5 \\
Stage 3 & 28 & 648.5 & 23.16 & 289.5
\end{tabular}

$\begin{array}{r}\text { Difference between } \\ \text { medians } \\ 95 \% \mathrm{CI}\end{array} \mid \begin{aligned} & \\ & - \\ & -\end{aligned}$

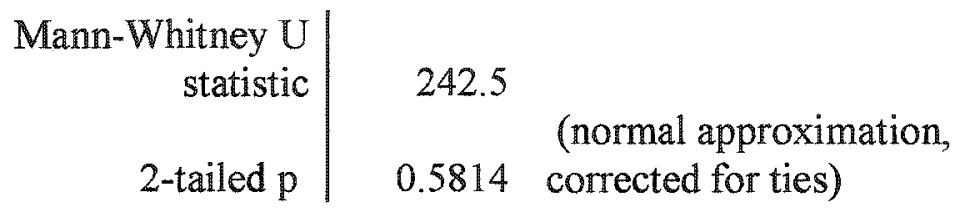


Comparing stages 3 and 4 :

n) 34

\begin{tabular}{r|r|r|r|r} 
Product type by Stage & $\mathrm{n}$ & $\begin{array}{c}\text { Rank } \\
\text { sum }\end{array}$ & \multicolumn{1}{|c|}{$\begin{array}{c}\text { Mean } \\
\text { rank }\end{array}$} & \multicolumn{1}{c}{$\mathrm{U}$} \\
\hline Stage 3 & 28 & 537.5 & 19.20 & 36.5 \\
Stage 4 & 6 & 57.5 & 9.58 & 131.5
\end{tabular}

$\begin{array}{r}\text { Difference between } \\ \text { medians } \\ 95 \% \mathrm{CI}\end{array} \mid$

\begin{tabular}{r|rr} 
Mann-Whitney U & & \\
statistic & 36.5 & \\
2-tailed p & 0.0188 & corrected for ties)
\end{tabular}




\section{A ppendix VI. Testing hypothesis 3}

Testing hypothesis 3a: Product diversity increases rapidly during the early adoption stages and then increases slowly over the later stages (Mann-Whitney U test).

Comparing stages 1 and 2 :

\section{n 141}

\begin{tabular}{r|r|r|r|r}
$\begin{array}{r}\text { Product diversity by } \\
\text { Stage }\end{array}$ & $\mathrm{n}$ & $\begin{array}{c}\text { Rank } \\
\text { sum }\end{array}$ & \multicolumn{1}{|c|}{$\begin{array}{c}\text { Mean } \\
\text { rank }\end{array}$} & \multicolumn{1}{c}{$\mathrm{U}$} \\
\hline Stage 1 & 129 & 8410.0 & 65.19 & 1523.0 \\
Stage 2 & 12 & 1601.0 & 133.42 & 25.0
\end{tabular}

\begin{tabular}{r|rlr}
$\begin{array}{r}\text { Difference between } \\
\text { medians }\end{array}$ & -0.02707 & & \\
$95.1 \% \mathrm{CI}$ & -0.11080 & 0.00666 & $\begin{array}{l}\text { (normal } \\
\text { approximation) }\end{array}$ \\
Mann-Whitney U & & \\
statistic & 1523 & \\
2-tailed $\mathrm{p}$ & $<0.0001$ & for ties)
\end{tabular}


Comparing stages 2 and 3 :
$\mathrm{n}$ 24

\begin{tabular}{r|r|r|r|r} 
Diversity by Stage & $\mathrm{n}$ & $\begin{array}{c}\text { Rank } \\
\text { sum }\end{array}$ & $\begin{array}{c}\text { Mean } \\
\text { rank }\end{array}$ & $\mathrm{U}$ \\
\hline Stage 2 & 12 & 142.0 & 11.83 & 80.0 \\
Stage 3 & 12 & 158.0 & 13.17 & 64.0
\end{tabular}

\begin{tabular}{r|lll} 
Difference between & & & \\
medians & -0.00004 & & \\
& & to & \\
$95.5 \% \mathrm{CI}$ & -0.00012 & 0.00015 & (exact)
\end{tabular}

\begin{tabular}{r|rc}
$\begin{array}{r}\text { Mann-Whitney U } \\
\text { statistic }\end{array}$ & 80 & \\
2-tailed p & 0.6707 & $\begin{array}{c}\text { (exact tables used, } \\
42 \% \text { ties) }\end{array}$
\end{tabular}


Comparing stages 3 and 4 :
n 15

\begin{tabular}{r|r|r|r|r} 
Diversity by Stage & $\mathrm{n}$ & $\begin{array}{c}\text { Rank } \\
\text { sum }\end{array}$ & $\begin{array}{c}\text { Mean } \\
\text { rank }\end{array}$ & \multicolumn{1}{c}{$\mathrm{U}$} \\
\hline Stage 3 & 12 & 105.0 & 8.75 & 9.0 \\
Stage 4 & 3 & 15.0 & 5.00 & 27.0
\end{tabular}

\begin{tabular}{r|lll}
$\begin{array}{r}\text { Difference between } \\
\text { medians }\end{array}$ & 0.00019 & & \\
& & to & \\
$95.2 \% \mathrm{CI}$ & -0.00093 & 0.00053 & (exact)
\end{tabular}

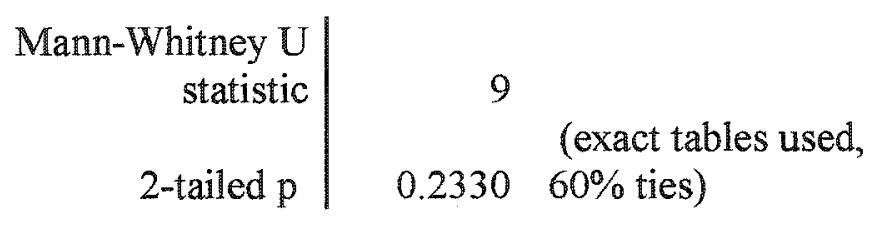




\section{Appendix VI. Testing Hypothesis $\mathbf{3}$ h}

Testing hypothesis 3b: Supplier diversity increases rapidly during the early stages, then increases slowly towards the later stages (Mann-Whitney U test).

Comparing stages 1 and 2 :
n 141

\begin{tabular}{r|r|r|r|r}
$\begin{array}{r}\text { Supplier diversity by } \\
\text { Stage }\end{array}$ & $\mathrm{n}$ & $\begin{array}{c}\text { Rank } \\
\text { sum }\end{array}$ & $\begin{array}{c}\text { Mean } \\
\text { rank }\end{array}$ & \multicolumn{1}{c}{$\mathrm{U}$} \\
\hline Stage 1 & 129 & 8439.5 & 65.42 & 1493.5 \\
Stage 2 & 12 & 1571.5 & 130.96 & 54.5
\end{tabular}

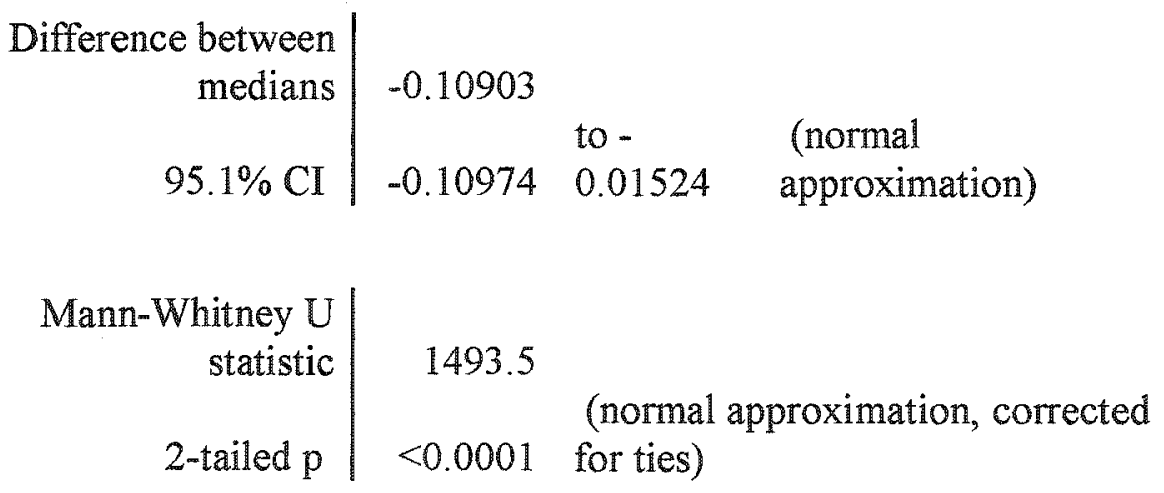


Comparing stages 2 and 3 :
$n$
24

\begin{tabular}{r|r|r|r|r}
$\begin{array}{r}\text { Supplier diversity by } \\
\text { Stage }\end{array}$ & $\mathrm{n}$ & $\begin{array}{c}\text { Rank } \\
\text { sum }\end{array}$ & $\begin{array}{c}\text { Mean } \\
\text { rank }\end{array}$ & $\mathrm{U}$ \\
\hline Stage 2 & 12 & 132.0 & 11.00 & 90.0 \\
Stage 3 & 12 & 168.0 & 14.00 & 54.0
\end{tabular}

\begin{tabular}{r|lll} 
Difference between & & & \\
medians & -0.00010 & & \\
& & to & \\
$95.5 \% \mathrm{CI}$ & -0.00097 & 0.00062 & (exact)
\end{tabular}

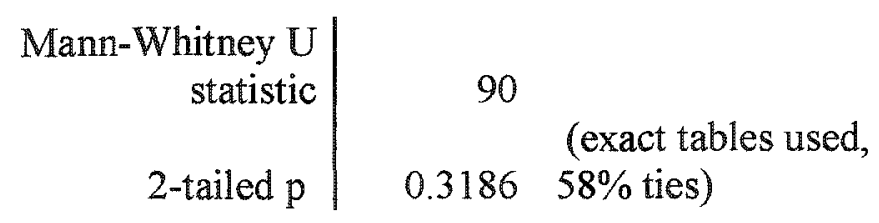


Comparing stages 3 and 4 :
n
15

\begin{tabular}{r|r|r|r|r}
$\begin{array}{r}\text { Supplier diversity by } \\
\text { Stage }\end{array}$ & $\mathrm{n}$ & $\begin{array}{c}\text { Rank } \\
\text { sum }\end{array}$ & $\begin{array}{c}\text { Mean } \\
\text { rank }\end{array}$ & \multicolumn{1}{c}{$\mathrm{U}$} \\
\hline Stage 3 & 12 & 102.0 & 8.50 & 12.0 \\
Stage 4 & 3 & 18.0 & 6.00 & 24.0
\end{tabular}

\begin{tabular}{r|lll}
$\begin{array}{r}\text { Difference between } \\
\text { medians }\end{array}$ & 0.00007 & & \\
& & & \\
& to & \\
$95.2 \% \mathrm{CI}$ & -0.00142 & 0.00081 & (exact)
\end{tabular}

\begin{tabular}{r|rl}
$\begin{array}{r}\text { Mann-Whitney U } \\
\text { statistic }\end{array}$ & 12 & (exact tables used, \\
2-tailed p & 0.4484 & $87 \%$ ties)
\end{tabular}


Appendix VIII. Testing hypothesis 3e

Hypothesis 3c: Buyer diversity increases rapidly during the early stages.

Comparing stages 1 and 2 :
n)
141

\begin{tabular}{r|r|r|r|r}
$\begin{array}{r}\text { Buyer diversity by } \\
\text { Stage }\end{array}$ & $\mathrm{n}$ & $\begin{array}{c}\text { Rank } \\
\text { sum }\end{array}$ & $\begin{array}{c}\text { Mean } \\
\text { rank }\end{array}$ & \multicolumn{1}{c}{$\mathrm{U}$} \\
\hline Stage 1 & 129 & 8385.0 & 65.00 & 1548.0 \\
Stage 2 & 12 & 1626.0 & 135.50 & 0.0
\end{tabular}

\begin{tabular}{r|rlr}
$\begin{array}{r}\text { Difference between } \\
\text { medians }\end{array}$ & -0.98047 & & \\
$95.1 \% \mathrm{CI}$ & -0.99174 & 0.97959 & $\begin{array}{c}\text { (normal } \\
\text { approximation) }\end{array}$ \\
to & & \\
Mann-Whitney U & & & \\
statistic & 1548 & \\
2-tailed p & $<0.0001$ for ties)
\end{tabular}


Comparing stages 2 and 3 :
n
24

\begin{tabular}{r|r|r|r|r}
$\begin{array}{r}\text { Buyer diversity by } \\
\text { Stage }\end{array}$ & $\mathrm{n}$ & $\begin{array}{c}\text { Rank } \\
\text { sum }\end{array}$ & $\begin{array}{c}\text { Mean } \\
\text { rank }\end{array}$ & \multicolumn{1}{c}{$\mathrm{U}$} \\
\hline Stage 2 & 12 & 81.0 & 6.75 & 141.0 \\
Stage 3 & 12 & 219.0 & 18.25 & 3.0
\end{tabular}

\begin{tabular}{r|lll}
$\begin{array}{r}\text { Difference between } \\
\text { medians }\end{array}$ & -0.01079 & & \\
& & to - & \\
$95.5 \% \mathrm{Cl}$ & -0.01766 & 0.00552 & (exact)
\end{tabular}

\begin{tabular}{r|rl} 
Mann-Whitney U & \\
statistic & 141 & \\
2-tailed p & $<0.0001$ & $\begin{array}{l}\text { (exact tables used, } \\
50 \% \text { ties) }\end{array}$
\end{tabular}


Comparing stages 3 and 4 :
n
15

\begin{tabular}{r|r|r|r|r}
$\begin{array}{r}\text { Buyer diversity by } \\
\text { Stage }\end{array}$ & $\mathrm{n}$ & $\begin{array}{c}\text { Rank } \\
\text { sum }\end{array}$ & $\begin{array}{c}\text { Mean } \\
\text { rank }\end{array}$ & \multicolumn{1}{c}{$\mathrm{U}$} \\
\hline Stage 3 & 12 & 85.0 & 7.08 & 29.0 \\
Stage 4 & 3 & 35.0 & 11.67 & 7.0
\end{tabular}

\begin{tabular}{r|lll}
$\begin{array}{r}\text { Difference between } \\
\text { medians }\end{array}$ & -0.00145 & & \\
& & to & \\
$95.2 \% \mathrm{CI}$ & -0.00372 & 0.00046 & (exact)
\end{tabular}

\begin{tabular}{r|rr} 
Mann-Whitney U & \\
statistic & 29 & (exact tables used, \\
2-tailed $\mathrm{p}$ & 0.1363 & $\begin{array}{l}\text { (53\% ties) } \\
53 \%\end{array}$
\end{tabular}




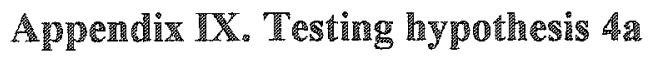

Hypothesis 4a: New buyers' entry rate follows a bell-shape distribution.

Comparing stages 1 and 2 :

n 141

\begin{tabular}{r|r|r|r|r}
$\begin{array}{r}\text { Buyer entry rate by } \\
\text { Stage }\end{array}$ & $\mathrm{n}$ & $\begin{array}{c}\text { Rank } \\
\text { sum }\end{array}$ & $\begin{array}{c}\text { Mean } \\
\text { rank }\end{array}$ & \multicolumn{1}{c}{$\mathrm{U}$} \\
\hline Stage 1 & 129 & 8602.5 & 66.69 & 1330.5 \\
Stage 2 & 12 & 1408.5 & 117.38 & 217.5
\end{tabular}

Difference between

\begin{tabular}{r|rcc} 
medians & -1.0 & & \\
& & & (normal \\
$95.1 \% \mathrm{CI}$ & -1.0 & to -1.0 & approximation)
\end{tabular}

\begin{tabular}{r|rl} 
Mann-Whitney U & \\
statistic & 1330.5 & \\
2-tailed p & $<0.0001$ for ties)
\end{tabular} 
Comparing stages 2 and 3 :
$\mathrm{n} \mid$
24

\begin{tabular}{r|r|r|r|r}
$\begin{array}{r}\text { Buyer entry rate by } \\
\text { Stage }\end{array}$ & n & $\begin{array}{c}\text { Rank } \\
\text { sum }\end{array}$ & $\begin{array}{c}\text { Mean } \\
\text { rank }\end{array}$ & U \\
\hline Stage 2 & 12 & 135.5 & 11.29 & 86.5 \\
Stage 3 & 12 & 164.5 & 13.71 & 57.5
\end{tabular}

\begin{tabular}{r|rl}
$\begin{array}{r}\text { Difference between } \\
\text { medians }\end{array}$ & $\begin{array}{l}-1.0 \\
-2.0\end{array}$ to $1.0 \quad$ (exact) \\
$95.5 \% \mathrm{CI}$ & -2.0 \\
Mann-Whitney U & & \\
statistic & 86.5 & (exact tables used, \\
2-tailed p & $0.4428 \quad 96 \%$ ties)
\end{tabular}


Comparing stages 3 and 4 :
n!
15

\begin{tabular}{r|r|r|r|r}
$\begin{array}{r}\text { Buyer entry rate by } \\
\text { Stage }\end{array}$ & n & $\begin{array}{c}\text { Rank } \\
\text { sum }\end{array}$ & $\begin{array}{c}\text { Mean } \\
\text { rank }\end{array}$ & U \\
\hline Stage 3 & 12 & 97.0 & 8.08 & 17.0 \\
Stage 4 & 3 & 23.0 & 7.67 & 19.0
\end{tabular}

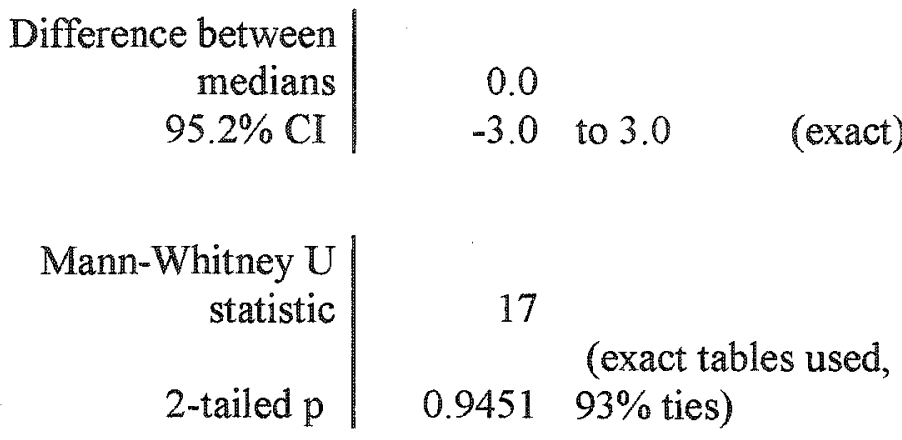




\section{Appendix X. Testing hypothesis $4 \mathrm{~b}$}

Hypothesis 4b: New suppliers' entry rate follows a bell-shaped distribution.

Comparing stages 1 and 2:

n 141

\begin{tabular}{r|r|r|r|r}
$\begin{array}{r}\text { Supplier entry rate by } \\
\text { Stage }\end{array}$ & $\mathrm{n}$ & $\begin{array}{c}\text { Rank } \\
\text { sum }\end{array}$ & $\begin{array}{c}\text { Mean } \\
\text { rank }\end{array}$ & \multicolumn{1}{c}{$\mathrm{U}$} \\
\hline Stage 1 & 129 & 8845.0 & 68.57 & 1088.0 \\
Stage 2 & 12 & 1166.0 & 97.17 & 460.0
\end{tabular}

\begin{tabular}{r|rc}
$\begin{array}{r}\text { Difference between } \\
\text { medians }\end{array}$ & -1.0 & \\
$95.1 \% \mathrm{CI}$ & -1.0 to 0 & $\begin{array}{c}\text { (normal } \\
\text { approximation) }\end{array}$ \\
Mann-Whitney U & & \\
statistic & 1088 & \\
2 2-tailed p & 0.0036 & for ties)
\end{tabular}


Comparing stages 2 and 3 :
$n$
24

\begin{tabular}{r|r|r|r|r}
$\begin{array}{r}\text { Supplier entry rate by } \\
\text { Stage }\end{array}$ & $\mathrm{n}$ & $\begin{array}{c}\text { Rank } \\
\text { sum }\end{array}$ & $\begin{array}{c}\text { Mean } \\
\text { rank }\end{array}$ & U \\
\hline Stage 2 & 12 & 152.0 & 12.67 & 70.0 \\
Stage 3 & 12 & 148.0 & 12.33 & 74.0
\end{tabular}

\begin{tabular}{r|rr} 
Difference between & & \\
medians & 0.0 & \\
$95.5 \% \mathrm{CI}$ & -1.0 to $1.0 \quad$ (exact) \\
Mann-Whitney U & & \\
statistic & 70 & (exact tables used, \\
2-tailed p & 0.9323 & $100 \%$ ties)
\end{tabular}


Comparing stages 3 and 4 :
呈
15

\begin{tabular}{r|r|r|r|r}
$\begin{array}{r}\text { Supplier entry rate by } \\
\text { Stage }\end{array}$ & $\mathrm{n}$ & $\begin{array}{c}\text { Rank } \\
\text { sum }\end{array}$ & $\begin{array}{c}\text { Mean } \\
\text { rank }\end{array}$ & \multicolumn{1}{c}{$\mathrm{U}$} \\
\hline Stage 3 & 12 & 99.0 & 8.25 & 15.0 \\
Stage 4 & 3 & 21.0 & 7.00 & 21.0
\end{tabular}

Difference between

medians

$95.2 \%$ CI

Mann-Whitney U statistic

2-tailed $p$
0.0

-2.0 to 2.0 (exact)

15

(exact tables used, 


\section{Appendiz X1. Testing hypothesis 5a}

Hypothesis 5a: Reasons for which suppliers commit to UML-based development tools are a function of the adoption stage.

Comparing stages 1 and 2 :
$\mathrm{n} \mid$
70

\begin{tabular}{r|r|r|r|l}
$\begin{array}{r}\text { Supplier reason by } \\
\text { Stage }\end{array}$ & $\mathrm{n}$ & $\begin{array}{c}\text { Rank } \\
\text { sum }\end{array}$ & $\begin{array}{c}\text { Mean } \\
\text { rank }\end{array}$ & $\mathrm{U}$ \\
\hline Stage 1 & 38 & 1304.5 & 34.33 & 652.5 \\
Stage 2 & 32 & 1180.5 & 36.89 & 563.5
\end{tabular}

\begin{tabular}{r|} 
Difference between \\
medians \\
$95 \% \mathrm{CI}$
\end{tabular} \mid $\begin{aligned} & \\
& \text { - }\end{aligned}$

\begin{tabular}{r|rr} 
Mann-Whitney U & & \\
statistic & 652.5 & \\
2-tailed p & 0.5895 & for ties)
\end{tabular}


Comparing stages 2 and 3 :
n!
67

\begin{tabular}{r|r|r|r|l}
$\begin{array}{r}\text { Supplier reason by } \\
\text { Stage }\end{array}$ & $\mathrm{n}$ & $\begin{array}{c}\text { Rank } \\
\text { sum }\end{array}$ & $\begin{array}{c}\text { Mean } \\
\text { rank }\end{array}$ & $\mathrm{U}$ \\
\hline Stage 2 & 32 & 1072.0 & 33.50 & 576.0 \\
Stage 3 & 35 & 1206.0 & 34.46 & 544.0
\end{tabular}

Difference between
medians
$95 \% \mathrm{CI}$

Mann-Whitney U statistic

2-tailed $p$
576

- to -

(normal approximation, corrected 0.8382 for ties) 
Comparing stages 3 and 4 :

\begin{tabular}{|c|c|c|c|c|}
\hline $\begin{array}{r}\text { Supplier reason by } \\
\text { Stage }\end{array}$ & $\mathfrak{n}$ & $\begin{array}{l}\text { Rank } \\
\text { sum }\end{array}$ & $\begin{array}{l}\text { Mean } \\
\text { rank }\end{array}$ & $\mathrm{U}$ \\
\hline Stage 3 & 35 & 710.5 & 20.30 & 59.5 \\
\hline Stage 4 & 4 & 69.5 & 17.38 & 80.5 \\
\hline
\end{tabular}

$\begin{array}{r}\text { Difference between } \\ \text { medians } \\ 95 \% \mathrm{CI}\end{array} \mid$ -

\begin{tabular}{r|rc}
$\begin{array}{r}\text { Mann-Whitney U } \\
\text { statistic }\end{array}$ & 59.5 & \\
2-tailed p & 0.6224 for ties)
\end{tabular}


Aprendix XI. Testing Dypothesis $5 \mathrm{~b}$

Hypothesis 5b: Reasons for which buyers commit to UML-based development tools are a function of the adoption stage.

Comparing stages 1 and 2 :

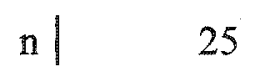

\begin{tabular}{r|r|r|r|r}
$\begin{array}{r}\text { Buyers' reasons by } \\
\text { Stage }\end{array}$ & $\mathrm{n}$ & $\begin{array}{c}\text { Rank } \\
\text { sum }\end{array}$ & $\begin{array}{c}\text { Mean } \\
\text { rank }\end{array}$ & \multicolumn{1}{c}{} \\
\hline Stage 1 & 7 & 101.0 & 14.43 & 53.0 \\
Stage 2 & 18 & 224.0 & 12.44 & 73.0
\end{tabular}

\begin{tabular}{r|rr}
$\begin{array}{r}\text { Difference between } \\
\text { medians } \\
95 \% \mathrm{CI}\end{array}$ & - & \\
& - to - \\
Mann-Whitney U & & \\
statistic & 53 & \\
2-tailed $\mathrm{p}$ & 0.5292 & corrected for ties)
\end{tabular}


Comparing stages 2 and 3 :

\begin{tabular}{r|r|r|r|r} 
n & \multicolumn{2}{|c}{46} & & \\
Buyers reasons by & & Rank & Mean & \\
Stage & n & sum & rank & U \\
\hline Stage 2 & 18 & 430.0 & 23.89 & 245.0 \\
Stage 3 & 28 & 651.0 & 23.25 & 259.0
\end{tabular}

\begin{tabular}{r|rr}
$\begin{array}{r}\text { Difference between } \\
\text { medians } \\
95 \% \mathrm{CI}\end{array}$ & - to - \\
\begin{tabular}{r|r} 
Manm-Whitney U \\
statistic
\end{tabular} & 245 & \\
2-tailed $p$ & 0.8703 & corrected for ties)
\end{tabular}


Comparing stages 3 and 4 :

\begin{tabular}{|c|c|c|c|c|}
\hline $\begin{array}{r}\text { Buyers' reasons by } \\
\text { Stage }\end{array}$ & $\mathrm{n}$ & $\begin{array}{c}\text { Rank } \\
\text { sum }\end{array}$ & $\begin{array}{c}\text { Mean } \\
\text { rank }\end{array}$ & $\mathrm{U}$ \\
\hline Stage 3 & 28 & 508.5 & 18.16 & 65.5 \\
\hline Stage 4 & 6 & 86.5 & 14.42 & 102.5 \\
\hline
\end{tabular}

Difference between medians $95 \%$ CI - to -

\begin{tabular}{r|rr}
$\begin{array}{r}\text { Mann-Whitney U } \\
\text { statistic }\end{array}$ & 65.5 & \\
2-tailed p & 0.3831 & $\begin{array}{c}\text { (normal approximation, } \\
\text { corrected for ties) }\end{array}$
\end{tabular}

